\title{
Effects of atmospheric acid deposition and single versus mixed leaf litters on foliar litter decomposition, carbon, nitrogen, phosphorus and calcium dynamics in a regenerating forest
}

Prinith Sumudu Munasinghe

West Virginia University

Follow this and additional works at: https://researchrepository.wvu.edu/etd

\section{Recommended Citation}

Munasinghe, Prinith Sumudu, "Effects of atmospheric acid deposition and single versus mixed leaf litters on foliar litter decomposition, carbon, nitrogen, phosphorus and calcium dynamics in a regenerating forest" (2008). Graduate Theses, Dissertations, and Problem Reports. 2635.

https://researchrepository.wvu.edu/etd/2635

This Thesis is protected by copyright and/or related rights. It has been brought to you by the The Research Repository @ WVU with permission from the rights-holder(s). You are free to use this Thesis in any way that is permitted by the copyright and related rights legislation that applies to your use. For other uses you must obtain permission from the rights-holder(s) directly, unless additional rights are indicated by a Creative Commons license in the record and/ or on the work itself. This Thesis has been accepted for inclusion in WVU Graduate Theses, Dissertations, and Problem Reports collection by an authorized administrator of The Research Repository @ WVU. For more information, please contact researchrepository@mail.wvu.edu. 
Effects of Atmospheric Acid Deposition and Single versus Mixed Leaf Litters on Foliar Litter Decomposition, Carbon, Nitrogen, Phosphorus and Calcium Dynamics in a regenerating Forest

\author{
Prinith Sumudu Munasinghe
}

Thesis submitted to the Davis College of Agriculture, Forestry, and Consumer Sciences at West Virginia University in partial fulfillment of the requirements for the degree of

\title{
Master of Science
}

in

Forestry

\author{
Kathryn Piatek, Ph.D., Chair \\ William Peterjohn, Ph.D. \\ Mary Beth Adams, Ph.D.
}

Division of Forestry and Natural Resources

Morgantown, West Virginia

2008

Keywords: Fernow Experimental Forest, acid deposition, nitrogen deposition, immobilization, mineralization 


\begin{abstract}
Effects of Atmospheric Acid Deposition and Single versus Mixed leaf litters on foliar litter decomposition, Carbon, Nitrogen, Phosphorus and Calcium dynamics in a regenerating forest

\section{Prinith Sumudu Munasinghe}

Increases in atmospheric $\mathrm{N}$ deposition over the past decades have raised concerns over nitrogen $(\mathrm{N})$ retention and carbon $(\mathrm{C})$ and nutrient cycling in forest ecosystems. We conducted two litter decomposition studies at the Long-Term Soil Productivity (LTSP) study at the Fernow Experimental Forest (FEF) in West Virginia. In the LTSP study acid deposition is simulated by periodic ammonium sulfate additions $(\mathrm{N}+\mathrm{S})$. Other treatments include control (ref) (no additions or reference) and ammonium sulfate plus lime (lime). Fresh litter was collected from treatment plots in November. Air-dried litter was weighed, and placed in nylon litter bags. Litter bags were placed in treatment plots in March after snow melt. Mass loss, C, N, P and Ca dynamics were followed for 12 months.
\end{abstract}

Study 1: To understand how acid deposition interacts to affect ecosystem C, N, P, and Ca cycling and to assess the ability of lime to counteract that effect, we followed decomposition of a litter mix representative of the forest floor composition (oak 48\%, yellow poplar 19\%, maple $14 \%$, magnolia $12 \%$, cherry $4 \%$, and birch 3\%). At 6 and 7 months remaining $\mathrm{N}$ content in litter in $\mathrm{N}+\mathrm{S}$ treatment was significantly lower than in reference and lime treatment $(\mathrm{p}<0.01)$ At 12 months, remaining mass was highest in lime treatment (43\%) and it was significantly higher than the $\mathrm{N}+\mathrm{S}(39 \%)$ and control (37\%). Remaining $\mathrm{C}$ at 12 months was significantly higher in $\mathrm{N}+\mathrm{S}$ $(42 \%)$ treatment than in reference $(36 \%)(\mathrm{p}=0.0337)$. Remaining $\mathrm{Ca}$ was significantly higher in $\mathrm{N}+\mathrm{S}$ treatment $(42 \%)$ than in reference $(36 \%)(\mathrm{p}=0.0051)$. At 12 months, the remaining $\mathrm{P}$ in the $\mathrm{N}+\mathrm{S}$ treatment $(107 \%)$ was significantly higher than in the control $(83 \%)$ and lime treatment (90\%). Lower $\mathrm{N}$ immobilization and higher $\mathrm{P}$ immobilization during leaf litter decomposition in $\mathrm{N}$ deposition treatments indicate that high rates of atmospheric $\mathrm{N}$ deposition may affect nutrient dynamics during litter decomposition. Our results also showed that lime plays a significant role in decreasing litter decay, increasing $\mathrm{N}$ immobilization and decreasing $\mathrm{P}$ immobilization, which shows the potential of lime on counteracting the effects of acid deposition.

Study 2: To understand the effects of single versus mixed litters and their interaction with acid and lime treatments on the decomposition of Quercus rubra (oak) litter, we looked at oak in three different litter types. The three litter types: 1 .ambient litter mix (48\% oak, 19\% poplar, 14\% maple, $12 \%$ magnolia, $4 \%$ cherry, and 3\% birch), 2. 50\% oak and 50\% maple leaves and 3. Pure oak. At each sampling oak leaves were sorted from other leaf litter species. Mass loss, C, N, $\mathrm{P}$, and $\mathrm{Ca}$ dynamics were quantified in oak decomposing alone (Oak), oak decomposing with maple (Oak+), and oak decomposing with maple, yellow poplar, magnolia, cherry and birch $(\mathrm{Oak}++)$. The decay constant $(k)$ was significantly higher in Oak $++(0.682)$ than in Oak + $(0.614)$ and in Oak $(0.595)(\mathrm{p}<0.0030)$. Throughout the 12 months of decomposition, $\mathrm{N}$ and $\mathrm{P}$ were immobilized in Oak, Oak+, and Oak++ litters in all treatments. Mass loss of oak was significantly affected by litter type. At 12 months, remaining mass of oak was significantly lower in Oak $++(46 \%)$ than in Oak $(53 \%)$ and Oak+ litter $(51 \%)(p<0.0001)$. Presence of other species significantly influenced oak decomposition but had no significant effect on $\mathrm{C}, \mathrm{N}, \mathrm{P}$ or Ca dynamics. 


\section{INTRODUCTION}

The northeastern USA receives the largest amounts of atmospheric $\mathrm{N}$ deposition in North America (Fenn et al., 1998). In central Appalachia, the Fernow Experimental Forest (FEF) in West Virginia receives about $17 \mathrm{~kg}$ of $\mathrm{N} \mathrm{ha}^{-1} \mathrm{yr}^{-1}$ and about $20 \mathrm{~kg}$ of S ha $\mathrm{yr}^{-1}$ through atmospheric deposition (Adams et al. 2000). The FEF also contains sites that have reached $\mathrm{N}$ saturation (Gilliam et al. 1996; Peterjohn et al. 1996 and Adams et al. 1997). A long term $\mathrm{NO}_{3}{ }^{-}$ increase in stream water has been observed at the FEF (Peterjohn et al. 1996). The possible chronic displacement of cations from the soil exchange sites could ultimately deplete the exchangeable pools of calcium and other base cations, which raises concerns about long-term soil productivity in impacted forests (Adams et al. 2004).

In addition to nutrient losses through leaching, timber harvesting removes a substantial amount of nutrients from a forest ecosystem. Nutrient removal is directly related to organic matter removal (Smith et al., 1986; Mann et al., 1988; Federer et al., 1989). Adams et al. (2000) reported that harvesting could also lead to short-term acidification in the soil solution by increased $\mathrm{N}$ cycling and nitrification rates.

Nutrient replenishment in terrestrial ecosystems is dependent to a large extent on the decomposition of plant litter (Knorr et al. 2005). For example, in natural perennial ecosystems a major portion of the plant $\mathrm{P}$ demand is provided by $\mathrm{P}$ cycling in organic residues (Halm et al. 1972; Miller et al. 1979; Attiwill 1980). Climate, litter chemistry, external inputs of nitrogen and the microbial decomposer community interact to determine the rate of litter decomposition and nutrient dynamics (Knorr et al. 2005).

Rates of litter decomposition vary among species (Melillo et al. 1982; Taylor et al. 1989). 
The influence of climate, quality of litter and the surrounding soil conditions on leaf decomposition has been well documented for single species litters (Gartner and Cardon, 2004). Much research has also been devoted to the prediction of behavior of mixed leaf litters, but relatively few studies have looked at the individual components in a given litter mix. This is important because leaf litter does not segregate into individual species in an ecosystem (Gartner and Cardon, 2004), and different leaf species in mixed litters may interact through physical, chemical, and biological processes during decomposition (Staff 1980; Seastedt 1984). Red oak is an important component of the Appalachian hardwood forest. In parts of the Fernow Experimental forest, WV (latitude $39^{\circ} 04^{\prime} \mathrm{N}$, longitude $79^{\circ} 41^{\prime} \mathrm{W}$ ), oak litter makes up $48 \%$ of the forest floor (Munasinghe et al. unpublished data).

The objectives of the two studies we carried out at the FEF were to evaluate: 1 . whether external $\mathrm{N}$ inputs have an effect on litter decomposition and on $\mathrm{C}, \mathrm{N}, \mathrm{Ca}$ and $\mathrm{P}$ dynamics in the forest litter floor of a regenerating hardwood forest, and 2. the role of lime in reversing these effects, and 3. to study the influence of other species in a mix plus its interaction with acid and lime treatments on oak decomposition and on $\mathrm{C}, \mathrm{N}, \mathrm{P}$, and $\mathrm{Ca}$ dynamics. 


\section{TABLE OF CONTENTS}

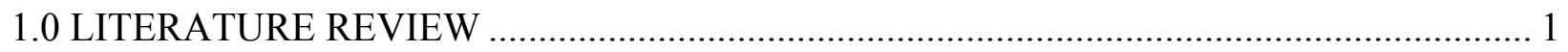

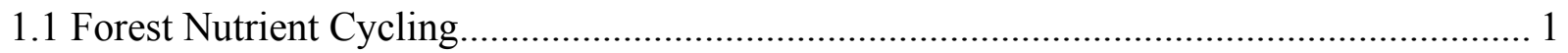

1.2 Effects of Acid Deposition on Nutrient Cycling ............................................................. 3

1.3 Effects of Harvesting on soil fertility and the nutrient cycles .......................................... 8

1.4 Resorption and it's effects on nutrient cycling and decomposition ................................... 10

1.5 Litter chemistry effects on litter decomposition .......................................................... 12

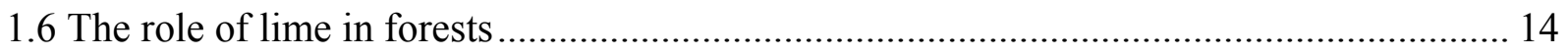

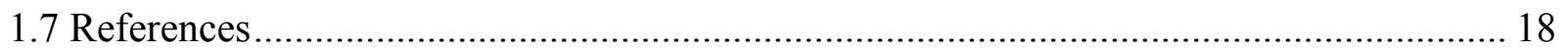

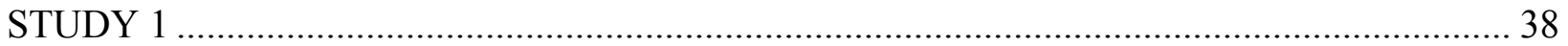

2.0 EFFECTS OF NITROGEN DEPOSITION ON FOLIAR LITTER DECOMPOSITION AND $\mathrm{C}, \mathrm{N}, \mathrm{CA}$, AND P DYNAMICS IN A CENTRAL HARDWOOD FOREST .............................. 38

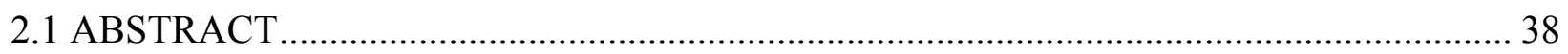

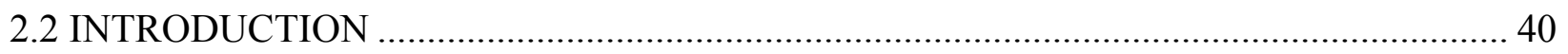

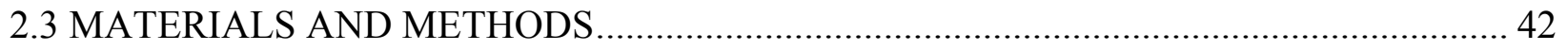

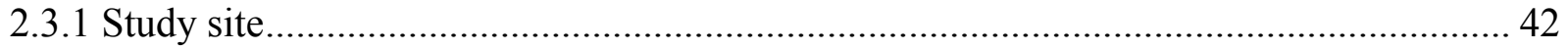

2.3.2 Foliar litter collection and litter bag preparation ........................................................... 43

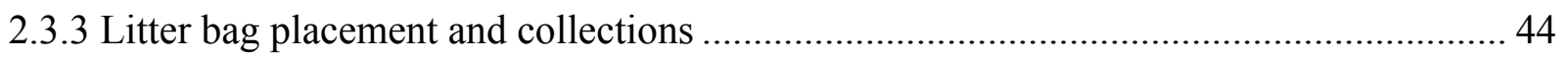

2.3.4 Nutrient analysis and mass loss measurements ............................................................ 44

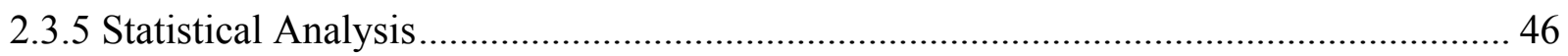

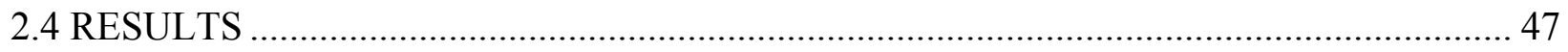

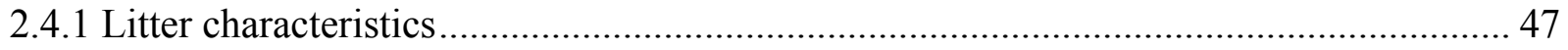

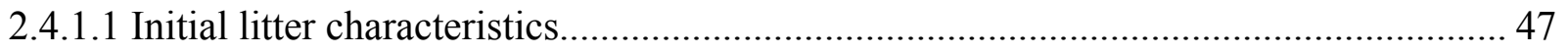

2.4.1. 2 Litter characteristics at 12 months ......................................................................... 47

2.4.1. 3 ANOVA for the Litter characteristics at 12 month................................................... 47

2.4.2 Treatment effects on litter decomposition/mass loss dynamics....................................... 48

2.4.3 Litter C dynamics..................................................................................................... 48

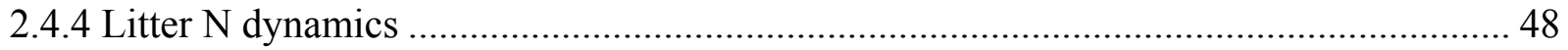

2.4.5 Treatment effects on litter Ca dynamics ..................................................................... 49

2.4.6 Treatment effects on litter P dynamics ....................................................................... 49

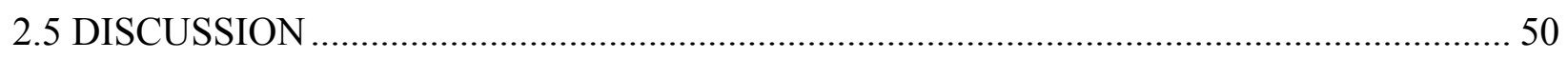

2.5.1 Litter decomposition / mass loss dynamics …………................................................. 50

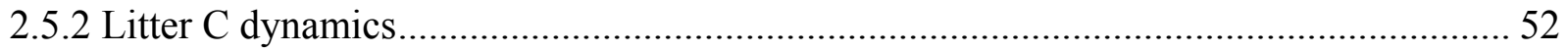

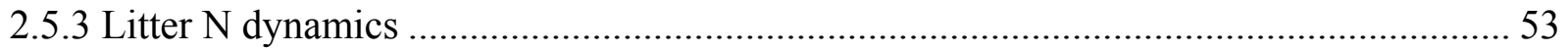




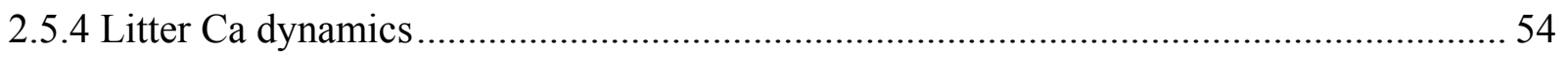

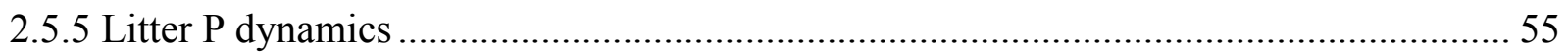

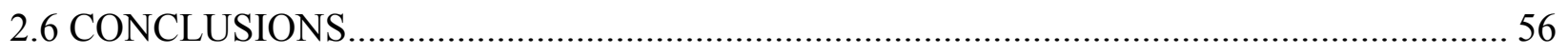

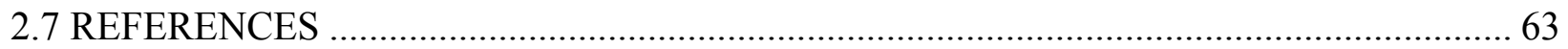

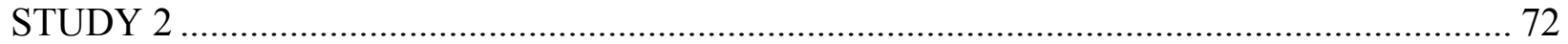

3.0 EFFECTS OF SINGLE-MIXED LEAF LITTERS AND ATMOSPHERIC ACID DEPOSITION ON MASS LOSS, C, N, P AND, CA DYNAMICS OF QUERCUS RUBRA IN A

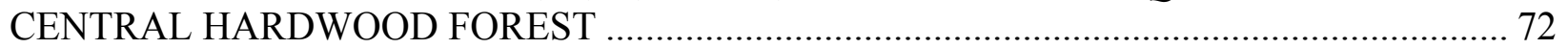

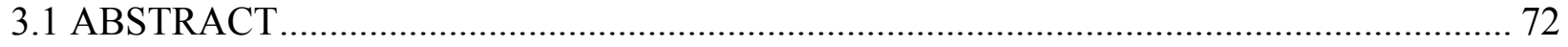

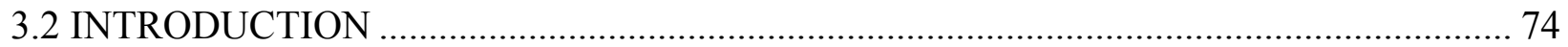

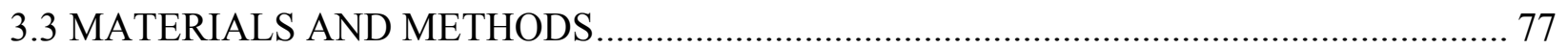

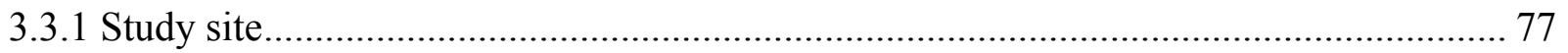

3.3.2 Foliar litter collection and litter bag preparation ...................................................... 78

3.3.3 Litter bag placement and collections .............................................................................. 79

3.3.4 Nutrient Analysis and mass loss measurements .......................................................... 79

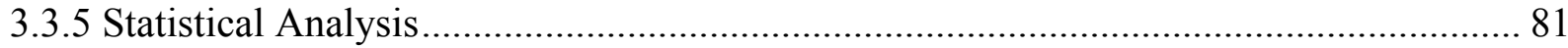

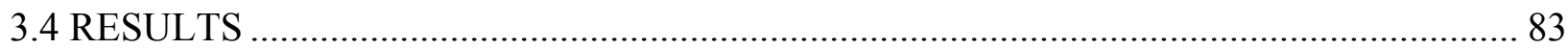

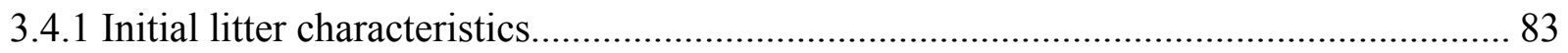

3.4.2 Single-mixed litter type effects on oak litter mass loss and nutrient dynamics in the

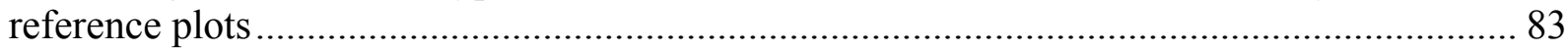

3.4.3 Treatment effects (reference, $\mathrm{N}+\mathrm{S}$, and lime) and treatment * oak litter (Oak, Oak+, and Oak++) interaction effects on decomposition, $\mathrm{C}, \mathrm{N}, \mathrm{P}$, and $\mathrm{Ca}$ dynamics. .............................. 84

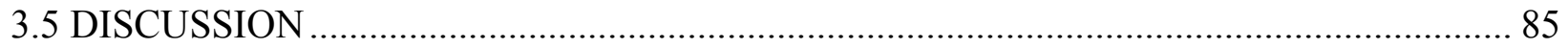

3.5.1 Mixed litter effects on mass loss and nutrient dynamics of oak litter ........................... 85

3.5.2 Acid deposition and lime effects on oak litter decomposition and nutrient dynamics .... 85

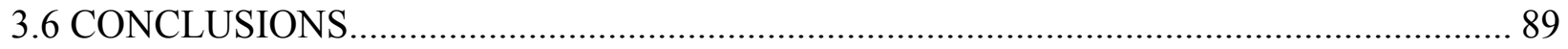

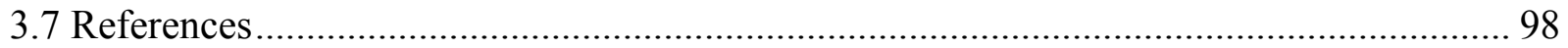

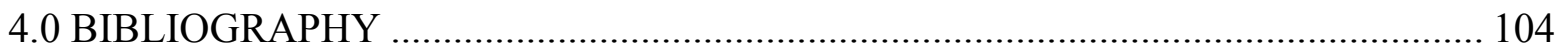




\subsection{LITERATURE REVIEW}

\subsection{Forest Nutrient Cycling}

Forest nutrient cycling has been a hot research topic for a long time. Pioneer work in forest nutrient cycles has been done by Ebermayer in 1876. In early times, focus has been on the measurement of pools of nutrients, present in plant and soil and the return of nutrients as litter fall. More recently, forest nutrient cycling is mainly focused on the processes of nutrient cycling with special interest on how those processes supply nutrients for sustained forest growth (Attiwill and Adams 1993). Today nutrient cycling is increasingly viewed as an ecosystem function impacted by man-made environmental changes such as atmospheric deposition. The development of ecosystem concept was initiated by Tansley in 1935. Since then "nutrient cycling in forests" was more generalized as "nutrient cycling and productivity in forest ecosystems" (Attiwill and Adams 1993). Another approach was the nutrient cycling studies within watershed systems such as the "Hubbard Brook Ecosystem" study in Northeastern United States. Nitrogen and phosphorous are the mostly discussed elements in forest nutrient cycles, particularly because these elements are often limiting to forest productivity. In this chapter, discussion is limited to C, $\mathrm{N}, \mathrm{Ca}, \mathrm{P}$, and $\mathrm{S}$ since these are the nutrients mostly affected by environmental pollution such as atmospheric acid deposition. When ecosystem approach is used, sources of nutrient inputs to the forest ecosystems can be by atmospheric deposition in the form of dust and rain-fall and by biological fixation via different types of micro-organisms. The output from the ecosystem would be by means of leaching of nutrients into stream water, volatilization and also by biological

processes such as denitrification. Within the forest ecosystem nutrients are released by weathering of rocks and minerals, they are taken up by plants from the soil and recycled back to 
the soil in the form of litter-fall, root exudates and by decay of above and below-ground biomass (roots).

Organic matter plays a major role in nutrient cycling in forest soils. In general, due to the fact of continuous input of woody litter, forest soils bare a higher $\mathrm{C} / \mathrm{N}$ ratio of around 15-30 than cultivated/agricultural soils, where the $\mathrm{C} / \mathrm{N}$ ratio is close to 10 (Paul and Clark 1989). As a result of the high $\mathrm{C} / \mathrm{N}$ ratio in forest soils, competition for $\mathrm{N}$ is high (Jansson 1958). Soil organic matter is the organic fraction of the soil exclusive of undecayed plant and animal residues (SSSA glossary). Further, one of the unique characteristic of forest soils is the bulk amount of root biomass in and on the surface of the mineral soil. Experimental data from the Hubbard Brook Experimental Forest in New Hampshire shows that, about $4 \mathrm{~kg} \mathrm{ha}^{-1}$ of carbon was released from a number of hardwood trees as root exudates, mostly in the form of organic acids (Smith 1976). Root exudates contribute to the nutrient cycling in forest soils by solubilizing complex nutrient compounds. Root exudates release organic carbon (Rovira 1969) in the forms of low-molecular weight exudates, high-molecular weight gelatinous mucilage, and sloughed-off cells (Marschner 1986) in to the forest soils. In particular, phosphorous availability is influenced by the low molecular weight root exudates and organic acids. Organic acids such as citric acid and malic acids solubilize less soluble phosphate complexes than other low molecular-weight root exudates (Attiwill and Adams 1993), making them available for plant uptake. 
In addition to root exudates, litter-fall is another main source of organic matter input to forest ecosystems. Litter decomposes and mineralizes with time, releasing its nutrients back to the ecosystem. Initial organic matter fragmentation takes place as macro fauna acts upon forest litter. During decomposition, carbon oxidization and $\mathrm{N}$ immobilization take place. These two processors lead to lower the $\mathrm{C} / \mathrm{N}$ ratio in the litter which increases gross mineralization. The residual substrates are further broken-down by microorganisms into inorganic nitrogen, phosphorous and other elements by oxidation and hydrolysis (Attiwill and Adams 1993). Released nutrients are taken up by plants, immobilized in microbial biomass and also leached from the rhizosphere, traveling to deeper soil layers and ultimately into stream water.

\subsection{Effects of Acid Deposition on Nutrient Cycling}

Elevated levels of sulfuric and nitric acid, through inputs of rain or snow are referred to as acid deposition (Fisher and Binkley 2000). Acidic substances could be deposited also in the

form of dust particles and vapor on the forest canopy (Schaefer et al. 1992). Further acid deposition includes gaseous emissions of sulfur dioxides $\left(\mathrm{S}_{2}\right)$, nitrogen oxides $\left(\mathrm{NO}_{\mathrm{x}}\right)$, ammonia $\left(\mathrm{NH}_{3}\right)$ and other acidifying compounds such as nitrates. Acid deposition could interact with many elements, such as $\mathrm{N}, \mathrm{S}, \mathrm{Ca}, \mathrm{Mg}$ and $\mathrm{Al}$ in terrestrial and aquatic ecosystems (Driscoll et al. 1996). Nitrate $\left(\mathrm{NO}_{3}{ }^{-}\right)$and sulfate $\left(\mathrm{SO}_{4}^{-2}\right)$ are the main anions that cause soil acidity and the consequent effects due to acid deposition. Anthropogenic activities have increased the amount of $\mathrm{N}$ entering the terrestrial ecosystems in the form of atmospheric $\mathrm{NO}_{3}{ }^{-}$deposition. Nitrates are highly mobile and binds with cations and leach away from the root zone eventually ending up in stream water. Increase $\mathrm{N}$ availability in temperate forests is a primary concern as it also has the potential to alter ecosystem scale C cycling by decreasing litter decomposition (Berg 1986; Fog 
1988; Berg and Matzner 1997). DeForest et al. (2004) showed that $\mathrm{NO}_{3}{ }^{-}$additions could also suppress microbial biomass.

Sulfate is the next most important anion which influences soil acidity, especially in the form of input from atmospheric deposition but also as a product of mineralization of organic matter. Factors that increase concentrations of $\mathrm{SO}_{4}^{-2}$ in the soil solution also increase the leaching of base cations from the soil (Valeur et al. 2000). Atmospheric acid deposition, S mineralization as well as $\mathrm{SO}_{4}^{-2}$ desorption increase the $\mathrm{SO}_{4}{ }^{-2}$ concentration in the soil solution (Valeur et al. 2000). Though $50 \%$ of the organically bound soil $\mathrm{S}$ is assumed to be inactive in turnover reactions, still a large pool of organic sulfur is available for release as an input from the mineralization process (Eriksen et al. 1995a,b). Sulfate adsorption potential in a given soil is considered to be directly related to the flux of $\mathrm{SO}_{4}{ }^{-2}$ and other cations associated in binding with $\mathrm{SO}_{4}{ }^{2-}$ ions (Johnson and Cole 1977, Johnson et al. 1983, Gaston et al. 1986). Cations are adsorbed with sulfate during sulfate retention (Johnson and Cole 1977; Cronan et al. 1978; Singh et al. 1980). Therefore the ability of the soil to retain sulfate helps to retain basic cations without leaching from the system.

Nitrogen saturation is defined as the availability of excess mineral $\mathrm{N}$ in excess of biotic demand (Aber et al. 1989). Effects of excess $\mathrm{N}$ deposition on nutrient cycling has been studied extensively. This chapter mainly addresses how acid deposition affects $\mathrm{N}$ cycling, $\mathrm{N}$ saturation conditions and thereby how it could affect other elemental nutrient cycles in forests. Atmospheric acid deposition has increased by 5-10 fold in the northeastern United States over pre-industrial conditions (Galloway et al. 1984), The concept that "excessive N could damage forest ecosystems" was suggested by Nihlgard in 1985. In the northeastern United States, dry and wet $\mathrm{N}$ deposition was reported as high as 10 to $12 \mathrm{~kg} \mathrm{ha}^{-1} \mathrm{yr}^{-1}$ in southern New York and 
Pennsylvania, to as low as less than $4 \mathrm{~kg} \mathrm{ha}^{-1} \mathrm{yr}^{-1}$ in eastern parts of Maine (Ollinger et al. 1993). Annual $\mathrm{NO}_{3}{ }^{-}$deposition in precipitation in Adirondack Park in New York was reported in the range of as low as $6.9 \mathrm{~kg} \mathrm{ha}^{-1} \mathrm{yr}^{-1}$ to as high as $38.6 \mathrm{~kg} \mathrm{ha}^{-1} \mathrm{yr}^{-1}$ (Ito et al. 2002).

Forest systems are often N limited (Mitchell and Chandler 1939, Aber et al. 1989, Aber 1992). In N limited systems, $\mathrm{NH}_{4}{ }^{+}$released during mineralization is either taken up by plants or immobilized in microbial biomass (Gilliam et al. 2001). Though the $\mathrm{N}$ turn-over rates can be high in $\mathrm{N}$ limited systems, $\mathrm{NH}_{4}{ }^{+}$availability for the nitrifying bacteria is very low (Davidson et al. 1992). Hence increased nitrification rates and higher levels of extractable $\mathrm{NO}_{3}{ }^{-} \mathrm{N}$ in mineral soils are symptoms of $\mathrm{N}$ saturation in forest systems (Aber et al. 1989, 1998).

Two hypothetical views have been proposed with regard to $\mathrm{N}$ saturation. One was proposed on the basis of forest processes (Aber et al. 1989, 1998) and the other was based on seasonal changes in $\mathrm{NO}_{3}{ }^{-}$concentrations in surface waters (Stoddard 1994). Both of these two hypotheses consider $\mathrm{NO}_{3}{ }^{-}$dynamics as the main characteristic of $\mathrm{N}$ status. The mobile nature of $\mathrm{NO}_{3}{ }^{-}$in soils (Aber et al. 2003) causes adverse effects such as acidification of soil and water bodies, increased $\mathrm{Al}$ mobility, increased $\mathrm{Al}$ content in streams, and also nutrient imbalances in trees (Vitousek et al. 1997, Aber et al. 1998, Fenn et al. 1998). Increased N concentrations in foliage and changes in $\mathrm{C} / \mathrm{N}$ ratios in soil are also indicators of changes in $\mathrm{N}$ status in forest ecosystems (Aber et al. 1989).

Symptoms of N saturation have been documented for many ecosystems (Fenn et al. 1998). The Fernow Experimental Forest (FEF) in West Virginia receives about 10 to $12 \mathrm{~kg}$ of $\mathrm{N}$ $\mathrm{ha}^{-1} \mathrm{yr}^{-1}$ and about $17 \mathrm{~kg}$ of S ha $\mathrm{yr}^{-1}$ through atmospheric deposition (Adams et al. 1997). A long term increase in $\mathrm{NO}_{3}{ }^{-} \mathrm{N}$ in stream water has been observed at FEF (Peterjohn et al. 1996). 
In contrast, Hubbard Brook Experimental Forest in New Hampshire receives $\mathrm{N}$ deposition at around 6 to $8 \mathrm{~kg} \mathrm{ha}^{-1} \mathrm{yr}^{-1}$, and has shown decreased $\mathrm{NO}_{3}{ }^{-}$losses in streams (Likens et al. 1996). These conflicting results indicate that temporal patterns of $\mathrm{NO}_{3}{ }^{-}$losses from forest ecosystems are affected by factors other than $\mathrm{N}$ itself (Aber et al. 2003).

Nitrogen saturation could accelerate leaching of base cations from the soil and this raises concerns over long-term soil nutrient status in forest soils (Adams et al. 2004). The immediate impact of $\mathrm{NO}_{3}{ }^{-}$leaching is the displacement of cations from the soil exchange sites. In soils having medium base saturation, $\mathrm{NO}_{3}^{-}$leaching causes removal of base cations from the root zone, creating potential nutrient deficiencies. Further, in more acidic soils with low base saturation, it could also increase $\mathrm{Al}$ mobilization into the soil solution, creating adverse effects on root activity and thereby on plant nutrient uptake (Miegroet et al. 1992). Therefore effects of enhanced $\mathrm{N}$ deposition on terrestrial ecosystems include soil chemical changes as such as increased acidification, increased $\mathrm{N}$ availability, enhanced $\mathrm{Al}$ mobility and reduced availability of Mg, Ca and K (Aber et al.1989, Johnson et al. 1994, Vitousek et al. 1997, DeHayes et al. 1999). Further it is well documented that soil chemical changes due to excess $\mathrm{N}$ deposition, have caused higher foliar $\mathrm{N}$ concentrations and lower concentrations of $\mathrm{Ca}, \mathrm{Mg}$ and $\mathrm{K}$ in forest tree species (Zoettl and Huettl 1986; Van Dijk and Roelofs 1988; Aber et al 1989; Cronan and Grigal 1995; Magill et al. 1997).

Calcium is a major cation affected by atmospheric acid deposition. There is evidence that the natural $\mathrm{Ca}$ cycling is affected by various anthropogenic factors, leading to $\mathrm{Ca}$ depletion in forest soils (Schaberg et al. 2001). Other than the acid deposition which is a major cause for $\mathrm{Ca}$ depletion in north temperate forests (Kirschner and Lydersen 1995; Likens et al. 1996, Likens et al. 1998; Hyman et al. 1998), lowered atmospheric base cation deposition (Edin et al. 1994), 
nitrogen saturation (Aber et al 1989; Aber et al. 1995; Schaberg et al. 1997) and harvest removal also influence $\mathrm{Ca}$ depletion. Calcium availability and cycling is determined by a number of natural processes including mineral weathering, atmospheric additions, plant up-take, forest stand dynamics, and leaching losses (Likens et al. 1998, McLaughlin and Wimmer 1999). Recent reports on Ca loss indicate that quantity of Ca loss may be substantial (Schaberg et al. 2001). Acidic deposition accelerates $\mathrm{Ca}$ losses by increasing $\mathrm{Al}$ solubility in soil. Aluminum displaces $\mathrm{Ca}$ from the exchangeable sites of the soil complex and $\mathrm{Ca}$ is then readily leach from the soil by binding with $\mathrm{SO}_{4}{ }^{2-}$ (Galloway et al. 1983; Reuss and Johnson 1986). Retention of $\mathrm{SO}_{4}{ }^{2-}$ in soils can delay the onset of acidification by reducing the sulfate flux through the soil, but the capacity of soils to retain $\mathrm{SO}_{4}{ }^{2-}$ is temporary. Therefore a substantial amount of $\mathrm{SO}_{4}{ }^{2-}$ is leached at the end (Swank and Crossley, 1988; Johnson and Van Hook, 1989; Huntington et al. 1994).

Based on long term biogeochemical studies, it is estimated that the pool of $\mathrm{Ca}$ in the soil complex at the Hubbard Brook Experimental forest may have decreased by more than $50 \%$ during the past 45 years (Likens et al. 1996). It is further estimated that the Ca loss would have been due to leaching caused by acid rain, decrease of $\mathrm{Ca}$ deposition and also due to the changing amounts of net Ca storage in tree biomass (Schaberg et al. 2001). Recent studies have shown that leaching of Ca from foliage could also be substantial. Mahony et al. (1997) reported a decline of healthy hardwood forests in Ontario, Canada possibly linked to lower $\mathrm{Ca}$ and $\mathrm{Mg}$ concentrations and $\mathrm{Ca} / \mathrm{Al}$ ratios in the soils. Further, sugar maple trees on declining sites showed lower $\mathrm{Ca}, \mathrm{Mg}$ and $\mathrm{P}$ concentrations and lower $\mathrm{Ca} / \mathrm{Al}$ ratios in the foliage, indicating acid leaching from the soil and the consequent altered mineral nutrition conditions in hardwood trees (Mahony et al. 1997). 
Large quantities of $\mathrm{Ca}$ are bound in most of the soil minerals and it is mainly supplied to plants by the weathering of minerals. This internal pool acts as a long term source of calcium for the cation exchange sites in the soil. Exchange complexes dominated by Ca maintain higher $\mathrm{pH}$ levels in soil. Calcium is the main component in plant cell walls. As Ca-containing minerals weather and release $\mathrm{Ca}^{2+}$ ions, plants take them up and convert to organic calcium compounds. Decay of plant materials releases $\mathrm{Ca}^{2+}$ back.

Acid rain and frequent harvesting have reduced the available calcium in forest ecosystems (Yanai et al. 2005). Acidic deposition accelerates Ca losses, due to the fact that increased acidity consequently increases the soluble $\mathrm{Al}$ and thereby $\mathrm{Al}$ replaces the $\mathrm{Ca}$ from the exchangeable sites in the soil (Galloway et al., 1983; Reuss and Johnson, 1986). Recent literature shows that atmospheric nitrogen deposition could saturate the forest's $\mathrm{N}$ demand (Aber et al. 2003). In Northeastern United States, red spruce decline has been related to the Ca deficiency in red spruce foliage (DeHayes et al. 1999). One of the most challenging issues is that Ca depletion may lead to a decline in forest productivity (Huntington et al. 2000).

\subsection{Effects of Harvesting on soil fertility and the nutrient cycles}

Tree harvesting could affect forest soil fertility as it removes a major portion of nutrients with removal of tree biomass. Many studies have shown that removals of nutrients increase with the quantity of biomass removed (Smith et al., 1986; Mann et al.,1988; Federer et al.,1989). Amount of nutrients removed from the system also depends on the type of biomass removed (Fisher and Binkley 2000). Nutrient quantities in above ground biomass of mature hardwood forest range from 143 to $323 \mathrm{~kg}_{\text {of N ha }}{ }^{-1}, 307$ to $1463 \mathrm{~kg}_{\text {of Ca ha }}{ }^{-1}$ and 20 to $62 \mathrm{~kg}$ of Mg ha (Adams et al. 2000). Foliage and bark have more nutrients than bole wood, hence, whole-tree 
harvesting removes more nutrients from the system than conventional harvesting which removes only boles (Fisher and Binkley 2000). Fisher and Binkley (2000) reported a comparison of whole tree harvesting and bole only harvesting with respect to nutrient input rates and site nutrient capitals.

According to the comparison made by Fisher and Binkley (2000), Ca is the most critical nutrient that could limit future forest productivity. The whole tree harvest removed about 240 year's equivalent of calcium inputs from precipitation, compared to 40 to 50 years worth of $\mathrm{N}$ and $\mathrm{P}$. Furthermore the $\mathrm{Ca}$ removed by the whole-tree harvest was more than double the $\mathrm{Ca}$ that was held on cation exchange sites, or $15 \%$ of the ecosystem capital to a soil depth of $45 \mathrm{~cm}$ (Fisher and Binkley 2000). Nutrient loss due to harvesting is also dependent on the rotation length. Longer rotations produce more wood with lower nutrient concentrations while shorter rotations produce small amounts of biomass which are high in nutrient concentrations (Fisher and Binkley 2000), therefore shorter the rotation period more nutrients will be removed from the system.

Harvesting results in micro-climatic changes such as increased soil temperature and soil moisture. This could result in increased leaching. Some experimental data on temperate and tropical forests show that nutrient removal through leaching is smaller compared to the nutrient removal from biomass (Fisher and Binkley 2000).

Forests having more calcium demanding tree species would be more susceptible to calcium losses from harvesting. Johnson et al (1988) has reported significant decrease in exchangeable $\mathrm{Ca}$ in the sub soils due to increased uptake of $\mathrm{Ca}$ by high calcium demanding tree species. Similarly, forests are more susceptible to base losses from harvesting when trees store 
more base nutrients in above ground biomass (Adams et al. 2000). Forests with large proportion of basswood (Tilia americana), yellow-poplar (Liriodendron tulipifera), oak (Quercus spp.), and hickories (Carya spp.) store large quantities of Ca in their bole wood (Raynal et al.,1992), thus, these type of forests could be more susceptible to nutrient depletion as a result of harvesting (Adams et al. 2000).

Harvesting of hardwood forests has increased in the eastern United States, especially in some parts of the Appalachian region. Increased harvesting has been observed in West Virginia, Tennessee, eastern Kentucky, and parts of Pennsylvania and New York (Adams et al. 2000). Therefore more research and policies would be necessary for the better understanding of the problem as well as to minimize the nutrient removal through harvesting.

\subsection{Resorption and it's effects on nutrient cycling and decomposition}

Plants absorb a considerable quantity of nutrients from leaves before leaf abscission. The process of resorption of nutrients from senescing leaves into storage tissues is called retranslocation and serves to conserve mineral nutrients. Forest trees re-translocate a sizeable proportion of leaf nutrients before leaf abscission (Kutbay and Ok 2003). Re-translocation increases the control of the individual plant over the nutrient resources and allows the plant to reutilize them (Mayor and Roda.1992; Tamm. 1964).

It has been suggested that trees growing in low fertile sites may use nutrients more efficiently than those growing in more fertile soils (Kutbay and Ok 2003). If this is true, then leaf litter on less fertile sites would have lower nutrient contents than litter on more fertile sites. According to Fisher and Binkley (2000), this idea appears to be incorrect. Birk and Vitousek 
(1984) found that leaves with higher concentrations of nitrogen had a greater re-translocation of nitrogen when expressed as milligrams of nitrogen recovered per leaf. Further, some fertilizer studies showed that greater amount of nitrogen was re-translocated from senescing needles of fertilized Scot's pine needles than from needles of control trees (Nambiar and Fife 1991. Nasholm (1994) also found that fertilized radiate pine tree needles had more nitrogen and the total nitrogen recovered per tree was three times greater for fertilized trees than for control trees (Fisher and Binkley 2000).

Each nutrient serves unique function in plants and their role affects the mobility of each element (Fisher and Binkley. 2000). For example $\mathrm{K}$ is an enzyme activator and regulator of osmotic potential and for these functions it remains a free mobile cation within the plant, therefore some $\mathrm{K}$ can undergo resorption before leaves fall. Calcium remains relatively immobile which results in less resorption before leaf fall. Nitrogen has a variety of different roles within a plant and hence mobility too varies accordingly (Fisher and Binkley. 2000). Resorption of N may depend more on the form of the $\mathrm{N}$ than on the nutritional status of the plant or ecosystem. Under luxury $\mathrm{N}$ regimes more mobile $\mathrm{N}$ compounds are accumulated within the plant whereas plants growing under $\mathrm{N}$ stress accumulate more insoluble structural $\mathrm{N}$ compounds. This explains the reason for higher retranslocation of nutrients in trees grown in more fertile sites than in trees grown on less fertile sites. Also it is found that internal recycling of nutrients is a more energy saving mechanism than nutrient uptake from soils ((Fisher and Binkley. 2000).

If foliar litter has more $\mathrm{N}$ at the beginning, there is more $\mathrm{N}$ available for the litter decomposing microorganisms. Therefore higher the re-translocation lesser would be the initial nutrient concentrations in the foliar litter, which would lower the decomposition rate. 


\subsection{Litter chemistry effects on litter decomposition}

There are three main levels of controls that affect litter decomposition in the following order: climate $>$ litter chemistry $>$ soil organisms (Swift et al. 1979). Based on this hierarchical model for litter decomposition (Swift et al. 1979; Lavelle et al. 1993), litter chemistry is the $2^{\text {nd }}$ main controlling factor in litter decomposition, and most important within areas of the same climatic influence (Berg 2000). Many chemical properties have been reported to influence litter decay including N concentration, C:N ratio (Coulson and Butterfield 1978; Berg and Staff 1980; Taylor et al. 1989; Tian et al. 1992a), P concentration or C:P ratios (Coulson and Butterfield 1978; Schelsinger and Hasey 1981; Staff and Berg 1982; Berg et al. 1987; Vitousek et al. 1994) and lignin concentration (Berg and Staff 1980; Melillo et al. 1982; Berg 1984; Tian et al. 1992b; Van Vuuren et al. 1993; Aerts and Decaluwe 1997).

In many studies $\mathrm{C}: \mathrm{N}$ ratio or $\mathrm{N}$ content have been reported as the most critical parameters for litter decay. Lignin content plays a major role in litter decomposition rate (Bollen 1953; Frogel and Cromack 1977). However in the tropics, $\mathrm{P}$ related parameters (lignin/P ratio, C/P ratio) are also important in controlling litter decay, since $\mathrm{P}$ availability is very low in those systems (Aerts and Decaluwe 1997). As temperate regions are mostly limited by $\mathrm{N}$ and therefore $\mathrm{N}$ has more control on litter decomposition (Vitousek and Howarth 1991).In litter where the lignin concentration is relatively low, lignin may not control litter decay (Taylor et al. 1989; Aerts and De Caluwe 1997). Therefore in such litters, other parameters control litter decay than lignin. In those type of litters high initial N, P, and $\mathrm{K}$ concentrations influence rapid initial decay rates but lowered decay rates in the long run. Aerts (1997) explained two reasons for this pattern. 1) During decomposition, the concentration of lignin increases. Nitrogen reacts with lignin and its degradation products and produces more recalcitrant products which are highly resistant to 
biological degradation. 2) Nitrogen can suppress the composition and activity of lignin degrading fungi. Litter with high $\mathrm{N}$ concentration may block the enzyme system of white rot fungi (Keyser et al. 1978) and would shift the fungi community from white- rot fungi to brownrot fungi. White-rot fungi are capable of degrading lignin completely whereas brown-rot fungi are only able to degrade lignin partially. During early stages of decay, concentrations of watersoluble substances in litter decrease rapidly (within a few months) before reaching a relatively stable level (Berg et al. 1987). During the early phase, free unshielded holocellulose is degraded while lignin either does not decompose or decomposes very slowly (Berg 2000). Therefore as other compounds decompose, lignin concentration starts to increase. Concentration of some nutrients such as N, P and S also start to increase (Staff and Berg 1982). In this early phase massloss rate may be related to total concentrations of major nutrients such as N, P and S which often limiting for decomposition (Berg and staff 1980). During the late stage of decomposition, concentrations of lignin, $\mathrm{N}$ and $\mathrm{P}$ increase with a linear relationship to accumulated mass loss (Staff and Berg 1982). As lignin concentration increase, litter decomposition rates are suppressed over time (Fogel and Cromack 1977; McClaugherty and Berg 1987). Therefore during late stages of decomposition, decay of remaining litter is controlled by the rate of lignin degradation. Atmospheric $\mathrm{N}$ deposition could alter litter decomposition by directly or indirectly altering litter decomposing microbial communities (De Forest et al. 2004). Decreased microbial biomass and activity have been reported as a result of $\mathrm{N}$ fertilization in forests (Bowden et al. 2004; Knorr et al. 2005). Ectomycorrhizal fungi are one group of microorganisms that have been reported as sensitive to excess $\mathrm{N}$ levels (Wallenda and Kottke 1998). Carreiro et al (2000) reported that $\mathrm{N}$ stimulated cellulose activity and inhibited phenol oxidase activity. Atmospheric $\mathrm{N}$ deposition could also modify soil microbial communities by suppressing the activity of lignin-degrading 
fungi (Berg 1986; Fog 1988; Dix and Webster 1995) thereby lowering the overall capacity of microbial communities to degrade lignin (Carreiro et al. 2000). Reduction in lignin degradation could reduce the amount of $\mathrm{C}$ available for other heterotrophic microorganisms (De Forest et al. 2004). For example cellulose is a major substrate for heterotrophic metabolism and decomposition of cellulose associated with lignin could be suppressed by excess N (De Forest et al. 2004), thereby diminishing heterotrophic microbial communities. Litter decomposition requires extracellular enzymes that break down organically bound N and P (Sinsabaugh et al. 2002). Nitrogen stimulates the degradation of labile, cellulosic organic matter and retards the decomposition of recalcitrant lignified organic matter (Fog 1988). Further, microbes assimilate anthropogenic $\mathrm{NO}_{3}{ }^{-}$and release $\mathrm{NH}_{4}{ }^{+}$(Zogg et al. 2000). High levels of $\mathrm{NH}_{4}{ }^{+}$in soil suppress lignin oxidation (Keyser et al. 1978) and therefore atmospheric $\mathrm{N}$ deposition especially in the form of $\mathrm{NO}_{3}^{-}$could potentially suppress the abundance of lignin-degrading fungi communities and their activity.

\subsection{The role of lime in forests}

Lime is applied to agricultural and forest soils with the main objective of neutralizing acidic conditions. Lime is also expected to be beneficial for plants, with an indirect advantage as a $\mathrm{Ca}$ and $\mathrm{Mg}$ supplement. This chapter mainly focuses on the liming of forest soils as an amelioration method under acidic conditions.

In addition to the efforts focused on reducing nitrogen and sulfur emissions to the atmosphere, measures have been taken to improve the chemical status of acidic forest soils by introducing alkaline substances such as lime (dolomite) (Valeur et al. 2000). Application of lime 
to forest ecosystems has produced contradictory results including either increasing (Baule \& Fricker 1970; Safford 1974) or decreasing (Derome et al. 1986; Fisher \& Binkley 2000) tree growth. Further, different liming methods could also result in different responses in the vegetation (Gregan et al. 1989). Liming increases soil $\mathrm{pH}$ thereby organic matter becomes more negatively charged as well as more water soluble. This renders organic matter more prone to microbial and biochemical reactions (Brunner \& Blaser 1989), which increases the rate of mineralization (Marschner \& Wilczynsh 1991; Baath et al. 1995; Eriksen et al. 1995a, b). Cations present in liming materials also affect organic matter reactions. Major portion of $\mathrm{Ca}^{+2}$ present in lime stabilizes the organic matter (Romkens et al. 1996), decreasing the production rates of dissolved organic carbon which leads to lowered organic matter decay rates. Lime applied to the forest floor could result in a more homogeneous distribution within the soil and thereby being available for many root systems, whereas broadcast lime could be available only for few roots because of its superficial distribution (Brach and Raynal 1992).

Liming has a great influence on the forest floor and as a whole on the forest biogeochemistry. Soil acidity is mainly caused by $\mathrm{NO}_{3}{ }^{-}$and $\mathrm{SO}_{4}^{-2}$ ions in the system. Large amount of lime is required to alter the soil pH (Fisher and D. Binkley. 2000). Many acid deposition studies have demonstrated liming effects on net $\mathrm{N}$ mineralization in forest soils (Nyborg and Hoyt 1978; Francis1982; Sahrawat et al. 1985; Persson et al. 1989). One of the hypothesis is that due to the application of lime, portion of organic matter gets mineralized and results in an increased microbial activity (Persson 1988). Net nitrification is strongly influenced by $\mathrm{pH}$ and it is expected to increase with pH. (Dancer et al. 1973; Heilman 1974; Nyborg and Hoyt 1978). Therefore though lime is applied to ameliorate soil acidity, it could generate acidic conditions which could counteract with the expected effects of liming (Driscoll et al. 1996). 
Simmons et al. (1996) investigated the effect of liming on increased nitrification and thereby its partial contribution to generate acidity.

Long-term studies by Shah et al. (1990) and Lyngstad (1992) showed that though the initial net $\mathrm{N}$ mineralization is increased due to lime, it declines in the subsequent growing seasons. In contrast, Simmons et al. (1996) found that liming of forest floor reduced net N mineralization and this was evident in both field and laboratory experiments. Furthermore, they investigated the long term response in net $\mathrm{N}$ mineralization as an effect of liming in watersheds. This reduction in net $\mathrm{N}$ mineralization could have been a result of increased immobilization by the microorganisms or due to a decrease in the net N mineralization. According to Simmons et al 1996, response of $\mathrm{N}$ mineralization to liming is complicated by three factors: 1 the response is a non linear function of $\mathrm{pH}, 2$ the response to a change in $\mathrm{pH}$ declines through time and 3 soil $\mathrm{pH}$ itself is variable through time. These factors make it difficult to predict long term effects of net $\mathrm{N}$ mineralization due to liming. Simmons et al 1996, concluded that, although lime application altered the nitrogen transformations in the forest soils, it has little impact on fertile soils as plants are not limited by nitrogen; on the other hand, liming in less fertile systems, such as coniferous forests with less available nitrogen is expected to have a big impact.

There are number of studies on the initial effects of liming on net sulfur mineralization (Freney \& Stevenson 1967; Williams 1967; Korentajer et al. 1983; Haynes \& Swift 1988; Marschner 1993). These studies show a short term increase in sulfur mineralization due to chemical hydrolysis of organic matter caused by the higher $\mathrm{pH}$. The long-term effect of liming on net sulfur mineralization is not very clear and conflicting results are reported (Marschner 1993). 
The overall view of our acidification study was to investigate, the effects of acid deposition (excess $\mathrm{N}$ in particular) on forest floor litter nutrient dynamics and litter decay and how it may affect on FEF ecosystem. In our $1^{\text {st }}$ case study, our objectives were, to 1) evaluate whether external $\mathrm{N}$ inputs have an effect on litter decomposition and on $\mathrm{C}, \mathrm{N}, \mathrm{Ca}$ and $\mathrm{P}$ dynamics in the forest floor and 2) see whether liming can reverse these effects. On our second case study, we looked at the decay rates and nutrient dynamics of Quercus rubra (oak) which was the major forest floor litter component at FEF. The objectives of the $2^{\text {nd }}$ study were, to 1) see whether the observed treatment effects on the forest floor (litter mix as a composite), is the same for the treatment effects on oak decomposition and $\mathrm{C}, \mathrm{N}, \mathrm{Ca}$ and $\mathrm{P}$ dynamics, 2) see whether decomposition and nutrient dynamics of oak is influenced by the presence of other leaf litters 


\subsection{References}

Aber, J., K. J. Nadelhoffer, P. Steudler, and J. M. Melillo.1989. Nitrogen saturation in northern forest ecosystems. Bio Science 39:378-386.

Aber, J. D. 1992. Nitrogen cycling and nitrogen saturation in temperate forest ecosystems. Trends in Ecology and Evolution 7:220-223.

Abe, J. D., A. Magill, S.G. McNulty, R. Boone, K. J. Nadelhoffer, M. Downs, and R. Hallet.1995. Forest biogeochemistry and primary production altered by $\mathrm{N}$ saturation. Water.Air.Soil.Pollut. 85:1665-1670.

Aber, J., W. McDowell, K. Nadelhoffer, A. Magill, G. Berntson, M. Kamakea, S. McNulty, W. Currie, L. Rustad and I. Fernandez.1998. Nitrogen saturation in temperate forest ecosystems. Bio Science 48:921-934.

Aber, J. D, C. L. Goodale, S. V. Ollinger, M. L. Smith, A. H. Magill, M. E. Martin, R. A. Hallett and J. L. Stoddard.2003. Is Nitrogen deposition altering the nitrogen status of northeastern forests? Bio Science 53:375-389. 
Adams, M. B., J. A. Burger, A. B. Jenkins, and L. Zelazny. 2000. Impact of harvesting and atmospheric pollution on nutrition depletion of eastern US hardwood forests. Forest Ecology and Management 138:301-319.

Adams, M. B., J. Burger, L. Zelazny, and J. Baumgras. 2004. Description of the Fork Mountain Long-term soil productivity study: site characterization. USDA, Forest Service. Northeastern Research Station Gen. Tech. Rep. NE-323. 19.

Aerts, R. 1997. Climate, leaf litter chemistry and leaf litter decomposition in terrestrial ecosystems: A triangular relationship.Oikos 79:439-449.

Aerts, R. and H. De Caluwe. 1997. Nutritional and plant mediated controls on leaf litter decomposition of Carex species. Ecology 78:244-260.

Attiwill, P. and M. A. Adams. 1993. Nutrient Cycling in Forests. New Phytol.124:561-582.

Baath E, A. Frostegtd, T. Pennanen and H. Fritze. (1995). Microbial community structure and $\mathrm{pH}$ response in relation to soil organic matter quality in wood-ash fertilized, clear-cut or burned coniferous forest soils. Soil Biol. Biochem. 27: 229-240 
Baule, H. and C. Fricker. (1970). The Fertilizer Treatment of Forest Trees. Translated by C.L. Whittles. BLV Verlagsgesellschaft, Munchen.

Brach, A. R. and D. J. Raynal. 1992. Effects of Liming on Oxalis acetosella and Lycopodium lucidulum in a Northern Hardwood Forest. The Journal of Applied Ecology 29:2: 492-500.

B. Berg and H. Staff. 1980. Decomposition rate and chemical changes in decomposing needle litter of Scots pine. II. Influence of chemical composition. In: Persson, T. (ed.), Structure and function of northern coniferous forest. Ecol. Bull.32:373-390.

Berg, B. 1984. Decomposition of moss litter in a mature Scots pine forest. Pedobiologia 26:301308.

Berg, B. 1986. Nutrient release from litter and humus in coniferous forest soils-a mini review. Scandinavian J. For. Res. 1:359-369.

Berg, B. and E. Matzner. 1997. Effect of nitrogen deposition on decomposition of plant litter and soil organic matter in forst systems. Environ. Rev.5:1-25. 
Berg, B., H. Staff, and B. Wessen. 1987. Decomposition and nutrient release in needle litter from nitrogen fertilized Scots pine (Pinus silvestris) stands. Scand. J. For. Res. 2:399-415.

Berg, B. 2000. Litter decomposition and oranic matter turnover in northern forest soils. Forest Ecology and Mangement 133:13-22.

Birk, E. and P. Vitousek. 1984. Patterns of N retranslocation in loblolly pine stands response to $\mathrm{N}$ availability. Bulletin of the Ecological Society of America 65:100.

Bollen, W. B. 1953. Mulches and soil conditioners. Carbon and nitrogen in farm and forest products. Agricultural and Food Chemistry 7:379-381.

Carreiro, M. M., R. L. Sinsabaugh, D. A. Repert, and D. F. Parkhurst. 2000. Microbial enzyme shifts explain litter decay responses to simulated N deposition. Ecology 81:2359-2365.

Coulson, J. C. and J. Butterfield. 1978. An investigation of the biotic factors determining the rates of plant decomposition on blanket bog. J. Ecol. 66:631-650. 
Cronan, C.S., W. A. Reiners, R. L. Reynolds, and G. E. Lang. 1978. Forest floor leaching: Contributions from mineral, organic, and carbonic acids in New Hampshire sub-alpine forests. Science 200:309-311.

Cronan, C.S. and D. F. Grigal. 1995. Use of Calcium/Aluminum ratios as indicators of stress in forest ecosystems. J. Environ. Qual. 24:209-226.

Dancer W. S., L. A. Peterson, and G. Chesters.1973. Ammonification and nitrification of N as influenced by soil pH and previous N treatments. Soil Sci. Soci. of America Proceedings 37: 6769.

Davidson, E. A., C. Stephen, H. Firestone, and M. K. Firestone. 1992. Internal cycling of nitrate in soils of a mature coniferous forest. Ecology 73:1148-1156.

De Forest, J. L., D. R. Zak, K. S. Pregitzer and A. J. Burton. 2004. Atmospheric nitrate deposition and the microbial degradation of cellulose and vanillin in a northern hardwood forest. Soil Biol. Biochem. 36:965-971.

DeHayes, D. H., P. G. Schaberg, G. J. Hawley and G. R. Strimbeck. 1999. Acid rain impacts on calcium and nutrition and forest health. Bio Science 10:789-800. 
Driscoll, C. T., C. P. Fahey, T. J. Blette, V. L. Bums, D. J. Gubala, C. P. Newton, R. M. Raynal, D. J. Schofield, C. F. Yavitt, and D. B. Porcella. 1996. The experimental watershed liming study (EWLS): Comparison of lakelwatershed base neutralization strategies. Biogeochemistry 32: 143174.

Dix, N.J. and J. Webster. 1995. Fungal Ecology. 48-52. Chapman and Hall. Boca Raton. FL.

Ebermayer, E. 1876. Die gesammte Lehre der Waldstreu, mit Rucksicht auf die chemische Statik des Waldbaues. Berlin: J. Springer.

Eriksen, J., R. D. B. Lefroy, and G. J. Blair. 1995a. Physical protection of soil organic S studied using acetylacetone extraction at various intensities of ultrasonic dispersion. Soil Biol. Biochem.27: 1005-1010.

Eriksen, J., R. D. B. Lefroy, and G. J. Blair.1995b. Physical protection of soil organic S studied by extraction and fractionation of soil organic matter. Soil Biol. Biochem. 27: 101 1-1016.

Federer, C. A., J. W. Hornbeck, L. M. Tritton, C. W. Martin, R. S. Pierce, and C. T. Smith. 1989. Long-term depletion of calcium and other nutrients in eastern US forests. Environ. Manage. 13:593-601. 
Fenn, M. E., M. A. Poth, J. D. Aber, J. S. Baron, B. T. Bormann, D. W. Johnson, A. D. Lemly, S. G. McNulty, D. F. Ryan, and R. Stottlemeyer. 1998. Nitrogen excess in North American ecosystems: Predisposing factors, ecosystem responses, and management strategies. Ecol. Appl. 8:706-733.

Fisher, R. F. and D. Binkley. 2000. Ecology and Management of forest soils. John Wiley and Sons Inc. New York.

Fog, K. 1988. The effect of added nitrogen on the rate of decomposition of organic matter. Bot. Rev.63:433-462.

Francis A. J. 1982. Effects of acidic precipitation and acidity on soil microbial processes. Water, Air \& Soil Pollution 18:375-394.

Freney J. R. and F. J. Stevenson.1967. Organic sulfur transformations in soils. Soil Sci. 101: 307-316.

Galloway, J. N., S. A. Norton, and M. R. Church. 1983. Freshwater acidification from atmospheric deposition of sulfuric acid: A conceptual model. Environ. Sci. Technol.17:541-545. 
Galloway, J. N., G. E. Likens, and M. E. Hawley. 1984. Acid precipitation: Natural versus anthropogenic components. Science.226:829-831.

Gaston, L. A., R. S. Mansell and R. D. Rhue. 1986. Sulfate mobility in acid soils and implications with respect to cation leaching: a review. Soil Crop Sci. Soc. Fla. Proc. 45:67-72.

Gilliam, F. S., B. M. Yurish, and M. B. Adams. 2001. Temporal and spatial variation of nitrogen transformations in nitrogen-saturated soils of a central Appalachian hardwood forest. Canadian Journal of Forest Research.31:1768-1785.

Gregan, P.D., J. R. Hirth and M. K. Conyers. 1989. Amelioration of soil acidity by liming and other amendments.Soil Acidity and Plant Growth (ed.) A.D. Robson. 205-264. Academic Press, New York.

Haynes R. J. and R. S. Swift.1988. Effects of lime and phosphate additions on changes in enzyme activities, microbial biomass and levels of extractable nitrogen, sulfur and phosphorus in an acid soil. Biol. Fertil. Soils 6:153-158.

Heilman, P. 1974. Effect of urea fertilization on nitrification in forest soils of the Pacific Northwest. Soil Science Society of America Proceedings 38: 664-667. 
Huntington, T. G., R. P. Hooper, and B. T. Aulenbach. 1994. Hydrologic processes controlling sulfur mobility: A small watershed approach. Water Resour. Res.30:283-295.

Huntington, T. G., R. P. Hooper, C. E. Johnson, B. T. Aulenbach, R. Cappellato and A. E. Blum. 2000. Calcium depletion in a southeastern United States forest ecosystem. Soil Sci.Soc. Am. J. 64:1845-1858.

Hyman, M. E., C. E. Johnson, S. W. Bailey, R. H. April and J. W. Hornbeck. 1998. Chemical weathering and cation loss in a base-poor watershed. GSA Bulletin 110:85-95.

Ito, M., M. J. Mitchell, and C. T. Driscoll. 2002. Spatial patterns of precipitation quantity and chemistry and air temperature in the Adirondack region of New York. Atmos. Environ. 36:10511062.

Jansson, S. L.1958. Tracer studies on nitrogen transformations in soil with special reference to mineralization-immobilization relationships. Kungl. Lantbruksshogskolans Annaler 24:101-361.

Johnson, D. W., and D. W. Cole. 1977. Sulfate mobility in an outwash soil in western Washington. Water Air Soil Pollut.7:489-495. 
Johnson, D. W., H. V. Miegroet, D. W. Cole, and D. D. Richter. 1983. Contributions of acid deposition and natural processes to cation leacing from forest soils: a review. J. Air Pollut. Control Assoc. 33:1036-1041.

Johnson, D. W. and R. VanHook .1989. Analysis of biogeochemical cycling processes in Walker Branch Watershed. Springer-Verlag, New York.

Johnson, A. H., T. N. Schwartzman, J. J. Battles, R. Miller, A. J. Friedland and D. R. Vann.1994. Acid rain and soils of the Adirondacks. II. Evaluation of calcium and aluminum as causes of red spruce decline at Whiteface Mountain, New York. Can. J. For. Res. 24:654-662.

Johnson, D. W., G. S. Henderson, and D. E. Todd. 1988. Changes in nutrient distribution in forests and soils of Walker Branch Watershed, Tennessee over an eleven year period. Biogeochemistry 5:275-293.

Keyser, P., T. K. Kirk, and I. G. Zeikus. 1978. Lignolytin enzyme of Phanerochaete chrysosporium: synthesized in the absence of lignin in response to nitrogen starvation. J. Bacteriol. 135:790-797. 
Kirchner, J. W. and E. Lydersen. 1995. Base cation depletion and potential long-term acidification of Norwegian catchments. Environmental Science and Technology 29:1953-1960.

Knorr, M., S. D. Frey, and P. S. Curtis. 2005. Nitrogen additions and litter decomposition: A meta analysis. Ecology 86:3252-3257.

Korentajer, L., B. H. Brynes, and D. T. Hellums.1983. The effect of liming and leaching on the sulfur-supplying capacity of soils. Soil Sci. Soc. Am. J. 47: 525-530.

Kutbay, H. G. and T. Ok. 2003. Foliar N and P resorption and nutrient levels along an elevational gradient in Juniperus oxycedrus L. subsp. macrocarpa (Sibth. \& Sm.) Ball. Ann. For. Sci. 60:449-454.

Lavelle, P., E. Blanchart, A. Martin, A. Spain, F. Toutain, I. Barois, and R. Schaefer. 1993. A hierarchical model for decomposition in terrestrial ecosystems: application to soils of the humid tropics. Biotropica 25:130-150.

Likens, G. E., C. T. Driscoll, and D. C. Buso. 1996. Long-term effects of acid rain: response and recovery of a forest ecosystem. Science 272:244-246. 
Likens, G. E., C. T. Driscoll, D. C. Buso, T. G. Siccama, C. E. Johnson, G. M. Lovett, T. J. Fahey, W. A. Reiners, D. F. Ryan, C. W. Martin and S. W. Bailey. 1998. The biogeochemistry of calcium at Hubbard Brook. Biogeochemistry 41:89-173.

Lyngstad, I. 1992. Effect of liming on mineralization of soil nitrogen as measured by plant uptake and nitrogen released during incubation. Plant and Soil 144: 247-253

Mahony, N., E. Nol, and T. Hutchinson. 1997. Food chain chemistry, reproductive success, and foraging behaviour of songbirds in acidified maple forests of central Ontario. Canadian journal of Zoology 75:509-517.

Mann, L. K., D. W. Johnson, D. C. West, D. W. Cole, J. W. Hornbeck, C. W. Martin, H. Riekerk, C. T. Smith, W. T. Swank, L. M. Tritton, and D. H. van Lear. 1988. Effects of wholetree and stem-only clearcutting on postharvest hydrologic losses, nutrient capital and regrowth. For. Sci. 34:412-428.

Marschner, H. 1986. Mineral nutrition of higher plants. London Academic Press Harcourt Brace Jovanovich. 
Marschner, B. and A. W. Wilczynski.1991. The effect of liming on quantity and chemical composition of soil organic matter in a pine forest in Berlin, Germany. Plant and Soil 137:229236.

Marschner, B. 1993. Microbial contribution to sulphate mobilization after liming an acid forest soil. J. Soil Sci. 44: 459-466.

Mayor, X. and F. Roda. 1992. Is primary production in holm oak forests nutrient limited? Plant Ecology 99:209-217.

McLaughlin, S. B. and R. Wimmer. 1999. Tansley Review:104: Calcium physiology and terrestrial ecosystem processes. New Phytologist 142:373-417.

McClaugherty, C., and B. Berg. 1987. Cellulose, lignin, and $\mathrm{N}$ concentrations as rate regulating factors in late stages of forest litter decomposition. Pedobiologia 30:101-112.

Melillo, J. M., J. D. Aber, and J. F. Muratore. 1982. Nitrogen and lignin control of hardwood leaf litter decomposition dynamics. Ecology 63:621-626. 
Miegroet, H. V., D. W. Cole, and N. W. Foster. 1992. Nitrogen distribution and cycling. In Johnson, D.C., and S.E. Lindberg (eds.). Atmospheric Deposition and Forest Nutrient Cycling: A synthesis of the Integrated Forest Study. Ecological Ser.91. Springer-Verlag, New York.

Mitchell, H. L., and R. F. Chandler, JR. 1939. The nitrogen nutrition and growth of certain deciduous trees of northeastern United States: with a discussion of the principles and practice of leaf analysis as applied to forest trees. The Black Rock Forest 11:1-94.

Nambiar, E. K. S. and D. N. Fife. 1991. Nutrient retranslocation in temperate conifers. Tree Physiology. 9:185-207.

Nasholm, T. 1994. Removal of nitrogen during needles senescence in Scots pine (Pinus sylvestris L.). Oecologia. 99:290-296.

Nihlgard, B.1985. The ammonium hypothesis, an additional explanation to the forest dieback in Europe. Ambio 14:2-8.

Nyborg, M. and P. B. Hoyt. 1978. Effects of acidity and liming on mineralization of soil nitrogen. Can. J. of Soil Sci. 58: 33 1-338. 
Ollinger, S. V., J. D. Aber, G. M. Lovett, S. E. Millham, R.G. Lathrop, and J. M. Ellis. 1993. A spatial model of atmospheric deposition for the northeastern Unites States. Ecological Applications 3:459-472.

Paul, E. A. and F. E. Clark. 1989. Soil microbiology and biochemistry. San Diego, Academic Press.

Persson T., J. Lundkvist, A. Wirh, R. Hyvonen, and, B. 'NessLn.1989. Effects of acidification and liming on carbon and nitrogen mineralization and soil organisms in mor humus. Water, Air and Soil Pollution 45:77-96.

Peterjohn, W. M., M. B. Adams, and F. S. Gilliam. 1996. Symptoms of nitrogen saturation in two central Appalachian hardwood forest ecosystems. Biogeochemistry 35:507-522

Raynal, D. J., N. W. Foster, M. J. Mitchell, and D. W. Johnson. 1992. Eastern hardwoods. In: D. W. Johnson, S. E. Lindberg (Eds.), Acidic deposition and forest nutrient cycling. Springer, New York, pp. 526-534.

Reuss, J. O., and D. W. Johnson. 1986. Acid deposition and acidification of soils and waters.Springer-Verlag, New York. 
Romkens, P. F., J. Bril, and W. Salomons. 1996. Interactions between $\mathrm{Ca}^{2+}$ and dissolved carbon: implications for metal mobilization. Appl. Geochem. 11: 109-1 15

Rovira, A. D. 1969. Plant root exudates. Botanical Review 35:35-37.

Safford, L.O. 1974. Effect of fertilization on biomass and nutrient content of fine roots in a beech-birch-maple stand. Plant and Soil 40: 349-363.

Sahrawat, K. L., D. R. Keeney and S. S. Adams. 1985. Rate of aerobic nitrogen transformations in six acid climax forest soils and the effect of phosphorus and $\mathrm{CaCO}_{3}$. For.Sci. 31 : 680-684.

Schaefer, D. A., P. Coklin, and K. Knoerr. 1992. Atmospheric deposition of acids. In Johnson, D.C., and S.E. Lindberg (eds.). Atmospheric Deposition and Forest Nutrient Cycling: A synthesis of the Integrated Forest Study. Ecological Ser.91. Springer-Verlag, New York.

Schaberg, P. G., T. D. Perkins, and S. G. McNulty. 1997. Effects of chronic low-level N additions on foliar elemental concentrations, morphology, and gas exchange of mature montane red spruce. Can. J. For. Res. 27:1622-1629. 
Schaberg, P. G., D. H. DeHayes, and G. Hawley. 2001. Anthropogenic Calcium depletion: A unique threat to forest ecosystem health Ecosystem Health. 7:214-228.

Schlesinger, W. H. and M. M. Hasey. 1981. Decomposition of chaparral shrub foliage: losses of organic and inorganic constituents from deciduous and evergreen leaves. Ecology 62:762-774.

Shah, Z., W. A. Adams and C. D. V. Haven. 1990. Composition and activity of the microbial population in an acidic upland soil and effects of liming. Soil Biol.and Biochemistry 22: 257-263

Singh, B. R., G. Abrahamsen and A. Stuanes.1980. Effects of simulated acid rain on sulfate movement in acid forest soils. Soil Sci. Soc. Am J. 44:75-80.

Sinsabaugh, R. L., M. M. Carreiro and D. A. Repert. 2002. Allocation of extracellular enzymatic activity in relation to litter decomposition, $\mathrm{N}$ deposition and mass loss. Biogeochemistry 60:1-24.

Simmons, J. A., J. B. Yavitt, and T. J. Fahey. 1996. Watershed Liming Effects on the Forest Floor N Cycle Biogeochemistry 32: 221-244.

Smith, W. H. 1976. Character and significance of forest tree root exudates. Ecology 57:324-331.

Smith, C. T., M. L. J. McCormack, J. W. Hornbeck, and C. W. Martin. 1986. Nutrient and biomass removals from a red spruce-balsam fir whole-tree harvest. Can. J. For. Res. 16:381-388. 
Staff, H. and B. Berg. 1982. Accumulation and release of plant nutrients in decomposing Scots pine needle litter. II. Long-tern decomposition in a Scots pine forest. Can. J. Bot. 60:1561-1568.

Stoddard, J. L. 1994. Long-term changes in watershed retention of nitrogen: Its causes and consequences. Pages 223-282 In Baker L. A. (Ed). Environmental Chemistry of Lakes and Reservoirs. American Chemical Society, Washington DC.

Swank, W. T., and D. A. J. Crossley. 1988. Forest hydrology and ecology at Coweeta. SpringerVerlag, New York.

Swift, M. J., O. W. Heal, and J. M. Anderson. 1979. Decomposition in Terrestrial Ecosystems. University of California Press Berkeley CA.

Tamm, C. O. 1964. Determination of nutrient requirements of forests of forest stands, In: Romberger J. A., Mikola P. (Eds.), International Review of Forestry Research, Academic Press, New York, 1964, pp. 115-170.

Taylor, B. R., D. Parkinson and W. F. J. Parsons. 1989. Nitrogen and lignini contents as predictors of litter decay rates: a microcosm test. Ecology 70:97-104. 
Tian, G., B. T. Kang and L. Brussaard. 1992a. Biological efforts of plant residues with contrasting chemical composition under humid tropical conditions-decomposition and nutrient release. Soil Biol. Biochem. 24:1051-1060.

Tian, G., B. T. Kang, and L. Brussaard. 1992b. Effects of chemical composition on N, Ca and $\mathrm{Mg}$ release during incubation of leaves from selected agroforestry and fallow plant species. Biogeochemistry 16:103-119.

Valeur, I., S. Andersson, I. Nilsson. 2000. Calcium Content of Liming Material and Its Effect on Sulphur Release in a Coniferous Forest Soil. Biogeochemistry 50:1:1-20

Van Vuuren, M. M. I., B. Van Wesemael and M. A. C. Veer. 1993. Soil organic matter accumulation, litter decomposition and humus forms under Mediterranean-type forets in southern Tuscany Italy. J. Soil Scie. 43:133-144.

Van Dijk, H. and J. G. M. Roelofs. 1988. Effects of excessive ammonium deposition on the nutritional status and condition of pine needles. Physiol. Plant. 73:494-501.

Vitousek, P. M., W. J. Parton, and R. L. Sanford. 1994. Litter decomposition on the Mauna Loa environmental matrix, Hawaii: patterns, mechanisms and models. Ecology 75:418-429. 
Vitousek, P. M., J. D. Aber, R. W. Howarth, G. E. Likens, P. A. Matson, D. W. Schindler, W. H. Schlesinger and D. G. Tilman. 1997. Human alteration of the global nitrogen cycle: sources and consequences. Ecol. Appl. 7:737-750.

Wallenda, T. and Kottke, I. 1998. Nitrogen deposition and Ectomycorrhiza. New Phytologist 139:169-187.

Williams, C. H. 1967. Some factors affecting the mineralization of organic sulfur in soils. Plant and Soil 26: 205-223.

Zoettl, H.W., and R.F. Huettl.1986. Nutrient supply and forest decline in southwest Germany. Water. Air. and Soil. Pollution 31:449-462.

Zogg, G., D. R. Zak, K. S. Pregitzer and A. J. Burton. 2000. Microbial immobilization and the 


\title{
STUDY 1
}

\subsection{Effects of Nitrogen deposition on foliar litter decomposition and C, N, Ca, and $P$ dynamics in a regenerating forest}

\author{
2.1 ABSTRACT \\ Increases in atmospheric $\mathrm{N}$ deposition over the past decades have raised concerns over \\ nitrogen $(\mathrm{N})$ retention and carbon $(\mathrm{C})$ and nutrient cycling in forest ecosystems. Implications for \\ $\mathrm{C}$ and nutrient cycling are particularly acute in forests with periodic biomass harvesting. To \\ understand how acid deposition interacts with harvesting removals to affect ecosystem $\mathrm{C}, \mathrm{N}$, \\ calcium $(\mathrm{Ca})$ and phosphorus $(\mathrm{P})$ cycling and to assess the ability of dolomitic lime to counteract \\ that effect, we followed decomposition and element dynamics in foliar litter at the Long-Term \\ Soil Productivity (LTSP) study at the Fernow Experimental Forest (FEF) in West Virginia. In the \\ LTSP study $\mathrm{N}$ deposition to a regenerating hardwood forest is enhanced by periodic ammonium \\ sulfate additions $(\mathrm{N}+\mathrm{S})$. Other treatments include reference (ref) plot (no additions) and \\ ammonium sulfate plus lime (lime). Fresh litter containing oak (48\%), yellow poplar (19\%), \\ maple (14\%), magnolia (12\%), cherry $(4 \%)$, and birch (3\%) was collected from treatment plots \\ in November. Air-dried litter was weighed, and placed in nylon litter bags. Litter bags were \\ placed in treatment plots in March after snow melt. Mass loss, $\mathrm{C}, \mathrm{N}, \mathrm{Ca}$ and $\mathrm{P}$ dynamics were \\ followed for 12 months. During the first 7 months of decomposition, $\mathrm{N}$ and $\mathrm{P}$ were immobilized \\ in litter in all treatments. At 6 months, $\mathrm{N}$ immobilization was significantly lower $(\mathrm{p}=0.006)$ in the \\ ammonium sulfate treatment $(117 \%)$ than in the reference $(128 \%)$ and lime $(125 \%)$ treatments. \\ At 7 months, $\mathrm{N}$ immobilization was significantly lower $(\mathrm{p}=0.009)$ in the $\mathrm{N}+\mathrm{S}$ treatment $(104 \%)$
}


than in the reference $(113 \%)$ and in lime $(115 \%)$ treatment. After twelve months, there were significant differences among treatments for mass loss, $\mathrm{C}, \mathrm{Ca}$, and $\mathrm{P}$ dynamics. Remaining mass was highest in lime treatment (43\%) and it was significantly higher than the N+S (39\%) and reference (37\%) treatments. Remaining $\mathrm{C}$ was higher in both lime (41\%) and $\mathrm{N}+\mathrm{S}(42 \%)$ treatments than in reference (36\%), and it was significantly different in ammonium sulfate treatment than in reference $(\mathrm{p}=0.0337)$. Remaining $\mathrm{Ca}$ was significantly higher in ammonium sulfate treatment $(42 \%)$ than in reference $(36 \%)(\mathrm{p}=0.0051)$. Nitrogen mineralized at 12 months in all treatments, and the remaining $\mathrm{P}$ in the $\mathrm{N}+\mathrm{S}$ treatment (107\%) was significantly higher than in the reference (83\%) and lime treatment $(90 \%)$. Increase in $\mathrm{N}$ and $\mathrm{P}$ contents during decomposition suggest that both $\mathrm{N}$ and $\mathrm{P}$ are limiting to microbial growth and forests. Decreasing $\mathrm{N}$ immobilization and increasing $\mathrm{P}$ immobilization during leaf litter decomposition in $\mathrm{N}$ addition treatments indicate that atmospheric $\mathrm{N}$ deposition may affect nutrient dynamics during litter decomposition and may have an impact on ecosystem scale $\mathrm{C}$ cycling and forest productivity. Our results also showed that lime plays a significant role in decreasing litter decay, increasing $\mathrm{N}$ immobilization and decreasing $\mathrm{P}$ immobilization, which shows the potential of lime to counteract the effects of $\mathrm{N}$ deposition. 


\subsection{INTRODUCTION}

The northeastern USA receives the largest amounts of atmospheric $\mathrm{N}$ deposition in North America (Fenn et al., 1998). Annual $\mathrm{NO}_{3}{ }^{-}$deposition in precipitation in the Adirondack National Park in New York was reported in the range of 6.9 to $38.6 \mathrm{~kg}$ of nitrate-N ha ${ }^{-1} \mathrm{yr}^{-1}$, while $\mathrm{SO}_{4}{ }^{2-}$ deposition in precipitation was reported in the range of 7.6 to $22.5 \mathrm{~kg}$ of sulfate-Sulfur ha ${ }^{-1} \mathrm{yr}^{-1}$ (Ito et al. 2002). In central Appalachia, the Fernow Experimental Forest (FEF) in West Virginia receives about $17 \mathrm{~kg}$ of $\mathrm{N} \mathrm{ha}^{-1} \mathrm{yr}^{-1}$ and about $20 \mathrm{~kg}$ of S ha ${ }^{-1} \mathrm{yr}^{-1}$ through atmospheric deposition (Adams et al. 2000). The FEF also contains sites that are nearing or have reached $\mathrm{N}$ saturation (Gilliam et al. 1996; Peterjohn et al. 1996 and Adams et al. 1997).

Nihlgard (1985) reported the potential of atmospheric $\mathrm{N}$ deposition to saturate biological demand and impact ecosystem processes. Two hypothetical views have been proposed with regard to $\mathrm{N}$ saturation. One was based on forest processes (Aber et al. 1989, 1998) and the other was based on seasonal changes in nitrate concentrations in surface waters (Stoddard 1994). Both of these hypotheses consider $\mathrm{NO}_{3}{ }^{-}$dynamics as the main characteristic of $\mathrm{N}$ status of forests. The mobile nature of $\mathrm{NO}_{3}^{-}$leads to adverse effects under $\mathrm{N}$ saturation conditions and these effects include acidification of soil and water bodies, increased aluminum mobility and increased aluminum contents in streams, excessive cation leaching, and nutrient imbalances in trees (Vitousek et al. 1997; Aber et al. 1998; Fenn et al. 1998). A long term $\mathrm{NO}_{3}{ }^{-}$increase in stream water has been observed at the FEF (Peterjohn et al. 1996). The possible chronic displacement of cations from the soil exchange sites could ultimately deplete the exchangeable pools of calcium 
and other base cations, which raises concerns about long-term soil productivity in impacted forests (Adams et al. 2004).

In addition to nutrient losses through leaching, timber harvesting removes a substantial amount of nutrients from a forest ecosystem. Nutrient removal is directly related to organic matter removal (Smith et al., 1986; Mann et al., 1988; Federer et al., 1989). Whole tree harvesting removes more biomass from the system and hence removes more nutrients than clear cutting (Adams et al. 2000). Adams et al. (2000) reported that harvesting could also lead to short-term acidification in the soil solution by increased $\mathrm{N}$ cycling and nitrification rates.

Nutrient replenishment in terrestrial ecosystems is dependent to a large extent on decomposition of plant litter (Knorr et al. 2005). For example, in natural perennial ecosystems a major portion of the plant $\mathrm{P}$ demand is provided by $\mathrm{P}$ cycling in organic residues (Halm et al. 1972; Miller et al. 1979; Attiwill 1980). Climate, litter chemistry, external inputs of nitrogen and the microbial decomposer community interact to determine the rate of litter decomposition and nutrient dynamics (Knorr et al. 2005). The relationship between litter decomposition and external $\mathrm{N}$ inputs is complex (Knorr et al. 2005). Some studies have reported accelerated decay rates in litter in response to increased external nitrogen inputs (Hunt et al. 1988; Carreiro et al. 2000; Hobbie 2000; Hobbie and Vitousek 2000). Many other studies, however reported either lowered decay rates (Magill and Aber 1998; Carreiro et al. 2000) or no significant change (McClaugherty et al. 1987; Pastor et al. 1987; Hunt et al. 1988; Prescott 1995; Bryant et al. 1998; Carreiro et al. 2000). The objectives of this study was to evaluate whether external $N$ inputs have an effect on litter decomposition and on $\mathrm{C}, \mathrm{N}, \mathrm{Ca}$ and $\mathrm{P}$ dynamics in the forest floor of a regenerating hardwood forest and whether liming can reverse these effects. 


\subsection{MATERIALS AND METHODS}

\subsubsection{Study site}

We conducted the experiment in the Long Term Soil Productivity (LTSP) Study located at the Fernow Experimental Forest (FEF) in Tucker County, West Virginia (latitude $39^{\circ} 04^{\prime} \mathrm{N}$, longitude $79^{\circ} 41^{\prime} \mathrm{W}$ ) on Fork Mountain (Adams et al. 2004). The site has a southeast aspect and the elevation ranges from $798 \mathrm{~m}$ to $847 \mathrm{~m}$. Land slope ranges from 15 to 31 percent (Adams et al. 2004). The LTSP experiment was established in 1996 with three objectives, to 1) characterize the productivity, diversity and biogeochemistry of a forest system under conditions of enhanced atmospheric deposition, 2) determine the response of the forest ecosystem to base cation removal, and 3) modify existing vegetation/nutrient/hydrologic models to describe and simulate forest changes due to base removals and acidic deposition (Adams et al. 2004). The LTSP experiment has four treatments replicated in four blocks at different slope positions: 1) Uncut and untreated control, 2) whole-tree harvesting, 3) whole-tree harvesting plus ammonium sulfate additions, and 4) whole-tree harvesting plus ammonium sulfate and dolomitic lime addition. Each experimental plot is 0.2 ha in size with a $7.6 \mathrm{~m}$ wide buffer strip (Adams et al. 2004). For our study we used three treatments: 1) whole-tree harvesting (reference), 2) whole-tree harvest + ammonium sulfate $(\mathrm{N}+\mathrm{S})$ additions (ammonium sulfate), and 3) whole-tree harvest + additions of both ammonium sulfate and dolomite (lime). The uncut and untreated control was not used in our study because those trees are older than the trees in rest of the plots. A total of 12 experimental plots ( 4 replicates per treatment) were used for this study. The ammonium sulfate treatment is designed to simulate acid deposition at twice the ambient rate in order to accelerate cation leaching from the soil. In the early 1980's, ambient atmospheric deposition rates of 
throughfall $\mathrm{N}$ and $\mathrm{S}$ in this region were $\sim 15$ and $17 \mathrm{~kg} \mathrm{ha}^{-1} \mathrm{yr}^{-1}$ respectively (Helvey and Kunkle 1986), therefore $36 \mathrm{~kg} \mathrm{~N}$ and $40 \mathrm{~kg} \mathrm{~S} \mathrm{ha}{ }^{-1}$ are added annually with the ammonium sulfate treatment. Enhanced deposition is applied three times a year in March, July and November. In March and November $34 \mathrm{~kg}$ of ammonium sulfate is applied ha ${ }^{-1}\left(7.1 \mathrm{~kg} \mathrm{~N} \mathrm{ha}^{-1}\right.$ and $8.1 \mathrm{~kg} \mathrm{~S}^{-}$ $\left.{ }^{1}\right)$, while in July $101 \mathrm{~kg}$ of ammonium sulfate is applied ha ${ }^{-1}\left(21.3 \mathrm{~kg} \mathrm{~N} \mathrm{ha}^{-1}\right.$ and $\left.24.4 \mathrm{~kg} \mathrm{~S} \mathrm{ha}^{-1}\right)$ (Adams et al. 2007). Stream water exports of $\mathrm{Ca}$ and $\mathrm{Mg}$ at the FEF for an untreated mature forested watershed (WS4) are about 11.25 and $5.83 \mathrm{~kg} \mathrm{ha}^{-1} \mathrm{yr}^{-1}$, respectively (Adams et al. 1997). Dolomitic lime is added every other year in March at a rate twice that of stream water export of $\mathrm{Ca}$ at the experimental site.

\subsubsection{Foliar litter collection and litter bag preparation}

Foliar litter was collected separately from each treatment plot from the top litter layer in December, 2005. Leaves were separated by species from individual plots and were pooled by treatment into northern red oak (Quercus rubra), maple species, yellow poplar (Liriodendron tulipifera), magnolia species, sweet birch (Betula lenta), and cherry species. The maple speices contained a mix of red maple (Acer rubrum) and sugar maple (Acer saccharum). The magnolia species contained both fraser magnolia (Magnolia fraseri) and cucumber magnolia (Magnolia acuminata). The cherry species contained a mix of black cherry (Prunus serotina) and pin cherry (Prunus pennsylvanica). From hereon, we refer the above as maple, magnolia, and cherry groups. Leaves were allowed to air dry for 10 days. The proportion of each leaf litter species in the litter bags was decided by the proportion of each litter species to the total leaf litter weight collected from the treatment plots. Relative weight by species and treatment was reproduced in litter bags. Each litter bag contained 48\% oak, 19\% poplar, 14\% maple group, 12\% magnolia 
group, $4 \%$ cherry group, and 3\% sweet birch. Litter bags were made of nylon with $2 \mathrm{~mm}$ mesh size and dimensions of $25 \times 22 \mathrm{~cm}$. Approximately $10 \mathrm{~g}$ (total weight) of air-dried leaf litter was placed in each litter bag. Three sub-samples for each leaf species were oven-dried at $65^{\circ} \mathrm{C}$ for 48 hours to determine their oven-dry weights. The difference between oven-dry and air-dry weight was used to calculate litter moisture content. Oven-dry weights of litter in each litter bag were estimated using the moisture content of each litter type.

\subsubsection{Litter bag placement and collections}

Litter collected from each treatment plot was allowed to decay in the same treatment plot, after the preparation of litter bags. Ten litter bags were placed in a random fashion in each experimental plot after snowmelt on March 15, 2006. Litter bags were placed on the mineral soil and held in place with landscape pins. Two bags were collected from each plot at 3, 6, 7, and 12 months after placement in the experiment site.

\subsubsection{Nutrient analysis and mass loss measurements}

After collection, litter bags were brought to the lab and manually cleaned of debris attached to the outer surface of the nylon bags. Leaf litter was sorted into species within one week of collection. Litter was dried in the oven for 48 hours at $65^{\circ} \mathrm{C}$ and weighed to the nearest hundredth gram. Mass loss over time $(w)$ was calculated using the following formula:

$w \frac{\left(W_{o}-W_{t}\right)}{W_{0}} \%$

$W_{t}=$ oven dry mass of litter remaining at time t. 
$W_{0}=$ initial oven dry mass of litter.

Litter decomposition rate/decay constant $(\mathrm{k})$ was calculated from the percentage of dry mass remaining using an exponential decay model (Olson, 1963):

$W_{t} / W_{0}=e^{-k t}$

$k=$ decay constant.

Oven-dried litter was ground separately by species and by treatment on a Wiley mill (60 mesh). The Willey mill was vacuum-cleaned between samples. Ground litter was re-dried, and 0.3 to 0.5 grams were weighed into tin capsules $(0.009 \times 0.005 \mathrm{~m})$, peletted, and analyzed for total C and N on a Carlo Erba NA 1500 NCS elemental analyzer with a Micro Dumas Combustion procedure. Approximately 0.2 grams of ground litter was weighed into digestion tubes and acid digested using $5 \mathrm{ml}$ of concentrated nitric acid and 30\% hydrogen peroxide at $125^{\circ} \mathrm{C}$ on a digestion block. The litter samples were digested for approximately 5 to 7 hours until they appeared colorless. The digested volume was brought up to $75 \mathrm{~mL}$ with deionized water and then filtered using $0.45 \mu \mathrm{m}$ nylon filters. Aliquots from the filtrate were used to measure total $\mathrm{Ca}$ using a Varian Spectra 220 atomic absorption spectrophotometer at $225 \mathrm{~nm}$ wavelength using nitrous oxide/acetylene gas. For total P measurement, $0.2 \mathrm{~mL}$ of the aliquot was mixed with 1.8 $\mathrm{mL}$ of Ammonium molybdate and allowed to sit for 5 minutes for the color development. Total P was measured at $550 \mathrm{~nm}$ wavelength using a Shimadzu 160U spectrophotometer (Taussky and Shorr 1953). Initial nutrient concentrations (C, N, Ca, and P), were measured for each group of species. The nutrient concentrations for each litter bag (c) and remaining nutrient contents (r) were estimated by the following formula: 
$c=\frac{\sum\left(W_{t}^{*} E_{t}\right)}{\sum W_{t}} \%$

$W_{t}=$ oven dry weights of oak, maple, poplar, magnolia, cherry, and birch at a given time

$E_{t}=$ elemental concentrations of $\mathrm{C}, \mathrm{N}, \mathrm{Ca}$, or $\mathrm{P}$ in oak, maple, poplar, magnolia, cherry and birch at a given time.

Remaining percent (r) of C, N, Ca, or P contents were estimated using the following equation:

$r=\frac{\sum\left(W_{t}^{*} E_{t}\right)}{\sum\left(W_{0}^{*} E_{0}\right)} \%$

$E_{0}=$ initial elemental concentrations of $\mathrm{C}, \mathrm{N}, \mathrm{Ca}$, or $\mathrm{P}$ in oak, maple, poplar, magnolia, cherry, and birch.

\subsubsection{Statistical Analysis}

Statistical analyses were conducted by three-way ANOVA using SAS software (SAS).

The main effects were treatment (reference, ammonium sulfate, and lime), block (1,2,3, and 4) and, sampling time (3, 6, 7, and 12 months). The data analysis was carried out under the assumption that the distribution of measured variables would behave normal. The initial nutrient concentrations $(\mathrm{C}, \mathrm{N}, \mathrm{Ca}$, and $\mathrm{P})$ and $\mathrm{C}$ :nutrient ratios $(\mathrm{C}: \mathrm{N}, \mathrm{C}: \mathrm{Ca}$, and $\mathrm{C}: \mathrm{P})$ were statistically analyzed by one-way ANOVA considering only the treatment effects. The main effects were considered significant at alpha $\leq 0.05$. Mean separation was performed using Tukey’s test. 


\subsection{RESULTS}

\subsubsection{Litter characteristics}

\subsubsection{Initial litter characteristics}

Initial litter nutrient concentrations $(\mathrm{C}, \mathrm{N}, \mathrm{Ca}$ and $\mathrm{P})$ and $\mathrm{C}$ :nutrient ratios $(\mathrm{C}: \mathrm{N}, \mathrm{C}: \mathrm{Ca}$, and $\mathrm{C}: \mathrm{P}$ ) did not significantly differ among treatments (Table 1). However, the $\mathrm{N}$ concentration was highest in the ammonium sulfate treatment $(1.21 \%)$ and lowest in the reference $(1.08 \%)$. Also, litter $\mathrm{Ca}$ concentration was highest in the lime treatment $(1.27 \%)$ and lowest in the ammonium sulfate treatment $(1.06 \%)$.

\subsubsection{Litter characteristics at 12 months}

Even after 12 months of decomposition, litters in the three treatments were not significantly different with respect to $\mathrm{C}: \mathrm{N}, \mathrm{C}: \mathrm{Ca}$, and $\mathrm{C}: \mathrm{P}$ ratios. Litter nutrient concentrations (C, N, Ca and P) did not significantly differ among treatments (Table 2).

\subsubsection{ANOVA for the Litter characteristics at 12 month}

ANOVA table for the ambient litter mix mass loss and nutrient dynamics data was significant for the treatment as well as for the treatment and time interaction. Block effect was not significant (Table 3). 


\subsubsection{Treatment effects on litter decomposition/mass loss dynamics}

There were no significant differences among treatments for mass loss for the first six months. (Fig. 1). By 12 months, however, remaining litter mass was significantly higher in the lime treatment (43\%) than in ammonium sulfate (39\%) and reference (37\%) treatments. At 12 months, lime treatment showed a significantly lower decomposition rate $(\mathrm{k}=0.823)$ than in reference $(\mathrm{k}=0.989)$ and ammonium sulfate $(\mathrm{k}=0.926)$ treatments $(\mathrm{p}=0.005)$.

\subsubsection{Litter C dynamics}

There were no significant differences among treatments for remaining $\mathrm{C}$ for the first 7 months (Fig. 2). At 12 months, however, remaining $\mathrm{C}$ was significantly different $(\mathrm{p}=0.028)$ among treatments and it was significantly higher in ammonium sulfate treatment (42\%) than in the reference $(36 \%)$ treatment $(\mathrm{p}=0.034)$.

\subsubsection{Litter $N$ dynamics}

The peak for $\mathrm{N}$ immobilization was observed at 6 months when the remaining $\mathrm{N}$ content was 122,119 and $111 \%$ in the reference, lime and ammonium sulfate treatments, respectively (Fig. 3). At both $6(\mathrm{p}=0.006)$ and 7 months $(\mathrm{p}=0.009)$, ammonium sulfate had significantly lower content of remaining $\mathrm{N}$ than the reference and lime treatments. In the first seven months, all litter exhibited net $\mathrm{N}$ immobilization irrespective of the treatment. At 7 months, remaining $\mathrm{N}$ content was 115,113 and $104 \%$ in lime, reference, and ammonium sulfate treatments, respectively. At 12 months, litter in all treatments showed net nitrogen mineralization and the remaining $\mathrm{N}$ 
content was 79,75 , and $74 \%$ in the reference, ammonium sulfate, and lime treatments, respectively.

\subsubsection{Treatment effects on litter Ca dynamics}

Ca was mineralized in all treatments during the 12 months of decomposition (Fig. 4). At 12 months, remaining calcium was $36 \%, 39 \%$, and $42 \%$ in the reference, lime, and ammonium sulfate treatments, respectively. Remaining $\mathrm{Ca}$ in the reference and ammonium sulfate treatment was significantly different $(\mathrm{p}=0.0051)$.

\subsubsection{Treatment effects on litter $P$ dynamics}

During the first 7 months, $\mathrm{P}$ was immobilized in all treatments. The peak for $\mathrm{P}$ immobilization was observed after 3 months of decomposition (Fig. 5). At that time, remaining $\mathrm{P}$ was greater in the lime treatment $(175 \%)$ than in the reference $(160 \%)$, and ammonium sulfate treatments $(128 \%)$. There was a highly significant $(\mathrm{p}=0.0001)$ treatment effect on the remaining $\mathrm{P}$ at 12 months. Litter in the ammonium sulfate treatment had a significantly higher remaining $\mathrm{P}$ $(107 \%)$ than in the reference $(83 \%)$, and lime $(90 \%)$ treatments. Throughout the decomposition process (except for $3^{\text {rd }}$ month observation), remaining $\mathrm{P}$ was always higher in the $\mathrm{N}+\mathrm{S}$ and lime treatments than in the reference litter (Fig. 5), showing that even after 12 months, litter in ammonium sulfate treatment was undergoing net $\mathrm{P}$ immobilization whereas litters in the reference, and lime treatments were undergoing net $\mathrm{P}$ mineralization. The switch from net $\mathrm{P}$ immobilization to net mineralization in the reference and lime treatment litter occurred somewhere between 7 and 12 months. 


\subsection{DISCUSSION}

\subsubsection{Litter decomposition / mass loss dynamics}

During the course of decomposition, litter in the lime treatment showed a lower decomposition rate compared to litters in the reference and ammonium sulfate treatments. At 7 months, remaining mass was significantly higher in lime treatment $(66 \%)$ than in the reference $(59 \%)(\mathrm{p}=0.020)$. At 12 months, remaining mass was significantly higher in lime treatment (43\%) than in the reference (37\%) and ammonium sulfate treatment (39\%), suggesting that lime may have an effect on suppressing litter decomposition $(\mathrm{p}=0.006)$. Application of lime to forest ecosystems has produced contradictory results, either increasing (Marschner and Wilczynsh 1991; Baath et al. 1995) or decreasing (Romkens et al. 1996) rates of decomposition. Romkens et al. (1996) reported that organic matter is stabilized by the $\mathrm{Ca}^{2+}$ ions present in lime. Therefore, lower rates of litter mass loss observed in our lime treatment could have been due to organic matter stabilization by $\mathrm{Ca}^{2+}$ ions present in lime.

Although the decomposition rates in ammonium sulfate and in the reference were not statistically significant, mass loss was always lower in the ammonium sulfate treatment than in the reference. Lower decomposition rates due to ammonium sulfate additions were reported by Adams and Angradi (1996). They carried out a litter decomposition study at a nearby watershed in the FEF where ammonium sulfate had been added in the same amount used in this experiment. They observed lower decomposition rates in yellow-poplar, black birch, and black cherry in the treated watershed (WS3) than in the reference watershed (WS7). Many other studies have also reported lowered decay rates (Magill and Aber 1998; Carreiro et al. 2000). However some studies have reported accelerated decay rates in litter in response to increased external nitrogen 
inputs (Hunt et al. 1988; Carreiro et al. 2000; Hobbie 2000; Hobbie and Vitousek 2000) or no significant change (McClaugherty et al. 1987; Pastor et al. 1987; Hunt et al. 1988; Prescott 1995; Bryant et al. 1998; Carreiro et al. 2000). Generally, high doses of external nitrogen accelerate decomposition when plant tissues have low contents of lignin and other recalcitrant compounds, but decelerate decomposition rate when high lignin contents are present (Berg, 1986; Fog, 1988; Berg and Matzner, 1997). Additions of $\mathrm{N}$ may inhibit the decomposition of lignin either by suppressing the synthesis of lignolytic enzymes or by influencing the formation of additional recalcitrant compounds, which are highly resistant to biological degradation (Keyser et al., 1978; Berg, 1986; Fog, 1988; Berg and Ekbohm, 1991; Berg and Matzner, 1997). Ammonium can suppress the activity of white rot fungi because high levels of $\mathrm{NH}_{4}{ }^{+}$inhibits their lignolytic enzymes (Berg 1986; Fog 1988).

In our experiment, $48 \%$ of each litter bag contained northern red oak. Oak leaves are highly lignified (Carreiro et al. 2000) and we assume that higher lignin content would have resulted in the observed lower decomposition in the treatment litter. We were not able to find any additional reports describing the role of lime on suppressing litter decomposition other than the explanation by Romkens et al. 1996. Other than litter quality, the degree and length of litter decomposition is also influenced by the application rate and the type of fertilizer applied, the amount of atmospheric $\mathrm{N}$ deposition, and the length of time which litter mass loss was measured (Knorr et al. 2005).

Litter in the reference plots did not get any additional $\mathrm{N}$ other than the $\mathrm{N}$ input from ambient atmospheric deposition. The annual decay rate constants (k) were $0.989,0.926$ and 0.823 for litter in the reference, ammonium sulfate, and lime treatments, respectively. Similar annual k values were reported by Adams and Angradi (1996) to be 0.893, 0.890, and 1.442 for 
black birch, yellow poplar, and black cherry in a litter decomposition study in WS3 at the FEF. Based on the results observed in our decomposition experiment, we could assume that the additional $\mathrm{N}$ and its effects on the litter carbon quality (mainly lignin) and also the role of $\mathrm{Ca}^{2+}$ ions would have been the determining factors for the treatment differences observed in litter decomposition rate/mass loss over time.

\subsubsection{Litter C dynamics}

During the process of decomposition, carbon becomes oxidized and lost as $\mathrm{CO}_{2}$ and dissolved organic carbon (DOC); some $\mathrm{C}$ may also be lost as organic matter that becomes fragmented and lost from the bag. These losses account for the decrease in the mass of litter. Therefore, the dynamics of $\mathrm{C}$ remaining in litter were similar to the dynamics of mass loss (decomposition) observed. At 3 months, litter $\mathrm{C}$ loss was greater in the ammonium sulfate treatment than in lime treatment and reference, but at 7 months there were no statistically significant differences among the treatments for litter carbon contents. At 12 months, more C remained in ammonium sulfate and lime treatments than in the reference. Fog (1988) explained that the response of organic matter to higher $\mathrm{N}$ concentrations may change through time, and litter mass loss and microbial respiration could increase at first, but the long-term responses could decrease. Higher remaining $\mathrm{C}$ observed in our study in both ammonium sulfate and lime treatments was probably due to the effect of excess $\mathrm{N}$ from ammonium sulfate and lime treatments on the decay of the residual litter with more recalcitrant compounds. Our findings are further supported by Fog (1988) who experimented on seven forested sites in western Washington and Oregon and reported that long-term elevated $\mathrm{N}$ can increase soil organic matter stability. 


\subsubsection{Litter $N$ dynamics}

Net immobilization was the dominant $\mathrm{N}$ process in litter irrespective of the treatment for 6 of the 12 months of decomposition. Adams and Angradi (1996) reported similar results of N immobilization in a watershed acidification study at the FEF. Nitrogen immobilization or an increase in $\mathrm{N}$ with time over initial $\mathrm{N}$ content during litter decomposition is a wide-spread phenomenon observed for different litter types and forests (Gosz et al. 1973; Berg and Ekbohm 1991; Piatek and Allen 2001; Bates et al. 2007). The occurrence of $\mathrm{N}$ immobilization is indicative of $\mathrm{N}$ limitation to decomposers and also perhaps for forest productivity. At the end of 12 months, litter of all three treatments in our study showed net nitrogen mineralization. The switch between $\mathrm{N}$ immobilization and mineralization occurred sometime between 6 and 7 months of decomposition. A lower remaining $\mathrm{N}$ content in the ammonium sulfate treatment indicated that there was a lower level of $\mathrm{N}$ retention in the litter, which suggest that doubling the rate of ambient atmospheric acid deposition lowers the rate of $\mathrm{N}$ immobilization during litter decomposition. A reduced rate of $\mathrm{N}$ immobilization under simulated atmospheric acid deposition could result in more $\mathrm{N}$ leaching from the forest floor, which could end up in surface water unless retained by some other mechanism (e.g. plant uptake). Hobbie (2000) reported that fertilization with $\mathrm{N}$ increased $\mathrm{N}$ immobilization in high lignin litter. We did not measure lignin in our experiment. Therefore, we are unable to relate $\mathrm{N}$ dynamics to lignin contents in the litter. The source of $\mathrm{N}$ for immobilization in our study could be from the soil, ammonium sulfate fertilizer applied on the plots, throughfall, or from $\mathrm{N}$ fixation by microorganisms in the forest floor. In our litter study, net $\mathrm{N}$ mineralization began somewhere between 6 (September) and 7 (October) months of decomposition, when the tree nutrient use shuts down at the end of the 
growing season. Therefore, the $\mathrm{N}$ that mineralized from litter during the above period may have leached in to streams or ground water.

\subsubsection{Litter Ca dynamics}

In all three treatments, calcium was mineralized (decreased in content over original) during the 12 months of decomposition (Fig. 4). Adams and Angradi (1996) reported an initial immobilization of $\mathrm{Ca}$ in black birch and black cherry litter and later mineralization. Initial $\mathrm{Ca}$ concentrations in those litters were $0.85,1.29,1.15$ and $1.06 \%$ for black birch, poplar, black cherry, and red maple leaf litter, respectively (Adams and Angradi 1996). In comparison, the initial $\mathrm{Ca}$ concentrations in our study were $1.25,1.27$, and $1.06 \%$ in reference, lime, and ammonium sulfate treatments. Although the initial $\mathrm{Ca}$ concentrations were approximately similar in the above two studies, Ca mineralization rates were different. By the end of the first year of the individual decomposition of black birch, black cherry, yellow poplar, and red maple, litters had approximately 20\% of remaining Ca (Adams and Angradi 1996), while treatment litter had 2 times more remaining calcium (40\%) in our study. The litter mix we studied contained $48 \%$ red oak. We assume that the presence of highly lignified red oak in our litter mix resulted in the above difference in the remaining $\mathrm{Ca}$ content. At 12 months, remaining $\mathrm{Ca}$ in the reference (36\%) was significantly lower than in the ammonium sulfate treatment (42\%), again suggesting that excess $\mathrm{N}$ may influence lower decomposition rates in highly lignified litter and consequently reducing Ca mineralization. 


\subsubsection{Litter P dynamics}

In our study, net $\mathrm{P}$ immobilization was greater than net $\mathrm{N}$ immobilization. Higher net $\mathrm{P}$ immobilization than $\mathrm{N}$ immobilization was also reported in Eucalyptus obliqua (Baker and Attiwill 1985) and in Eucalyptus diversicolor forests (O’Connell 1988). Adams and Angradi (1996) reported an early P increase during the first 6 months of decomposition in red maple, black birch, and cherry litter due to net $\mathrm{P}$ immobilization in another study at the FEF. In our study, $\mathrm{P}$ was immobilized in all treatments during the first 3 months (Fig. 5). The switch between $\mathrm{P}$ immobilization and mineralization occurred sometime between 3 and 6 months of decomposition. 


\subsection{CONCLUSIONS}

Our results suggest that simulated atmospheric acid deposition at twice the ambient rates may alter litter nutrient dynamics by altering $\mathrm{N}$ and $\mathrm{P}$ cycling in a 10-year old regenerating forest. This effect was observed 10 years after the treatment started; no earlier data are available. Based on 12 months data, lime treatment appears to alleviate the effects of atmospheric $\mathrm{N}$ deposition by increasing $\mathrm{N}$ immobilization, $\mathrm{Ca}$ mineralization, and by lowering $\mathrm{P}$ immobilization during leaf litter decomposition. Immobilization of $\mathrm{N}$ and $\mathrm{P}$ during litter decomposition suggests that $\mathrm{N}$ and $\mathrm{P}$ are both limiting for microbial growth and forests. Most temperate forests are $\mathrm{N}$ and $\mathrm{P}$ limited and atmospheric $\mathrm{N}$ deposition could further aggravate the extent of $\mathrm{P}$ limitation (Gress et al. 2007). Our results also suggest that if atmospheric acid deposition could suppress

litter decomposition, long-term elevated $\mathrm{N}$ may have a substantial impact on $\mathrm{C}$ sequestration and eventually on the global $\mathrm{C}$ budget. 
List of tables and figures

Table.1. Initial nutrient concentrations and C:nutrient ratios in litter for reference, lime, and ammonium sulfate treatment plots $(\mathrm{C}, \mathrm{N}$, and $\mathrm{Ca}$ in $\%$ basis and $\mathrm{P}$ in $\mathrm{mg} / \mathrm{kg})$

\begin{tabular}{llllllll}
\hline Treatments & $\mathrm{C}$ & $\mathrm{N}$ & $\mathrm{Ca}$ & $\mathrm{P}$ & $\mathrm{C}: \mathrm{N}$ & $\mathrm{C}: \mathrm{Ca}$ & $\mathrm{C}: \mathrm{P}$ \\
\hline Reference & 48.5 & 1.08 & 1.25 & 526 & 44.9 & 38.8 & 921 \\
Lime & 48.5 & 1.14 & 1.27 & 511 & 42.4 & 38.1 & 953 \\
Ammonium & 48.9 & 1.21 & 1.06 & 525 & 40.5 & 46.5 & 933 \\
sulfate & & & & & & & \\
\hline
\end{tabular}

$\uparrow$ None of the above parameters are significantly different among treatments

Table. 2. Nutrient concentrations and C:nutrient ratios in litter at 12 months in reference, lime and ammonium sulfate treatment plots $(\mathrm{C}, \mathrm{N}$, and $\mathrm{Ca}$ in $\%$ basis and $\mathrm{P}$ in $\mathrm{mg} / \mathrm{kg})$

\begin{tabular}{llllllll}
\hline Treatments & $\mathrm{C}$ & $\mathrm{N}$ & $\mathrm{Ca}$ & $\mathrm{P}$ & $\mathrm{C}: \mathrm{N}$ & $\mathrm{C}: \mathrm{Ca}$ & $\mathrm{C}: \mathrm{P}$ \\
\hline Reference & 46.6 & 2.09 & 1.29 & 940 & 21.5 & 35.2 & 505 \\
Lime & 47.7 & 2.21 & 1.37 & 927 & 21.6 & 41.1 & 519 \\
Ammonium & 47.1 & 2.38 & 1.12 & 881 & 20.6 & 42.5 & 538 \\
sulfate & & & & & & & \\
\hline
\end{tabular}

$\uparrow$ None of the above parameters are significantly different among treatments

Table.3. ANOVA table for study 1

\begin{tabular}{lllll}
\hline Sources & DF & SS & F value & $\operatorname{Pr}>F$ \\
\hline Treatment & 2 & 0.90 & 14.66 & $<0.0001$ \\
Block & 3 & 0.92 & 2.05 & 0.1259 \\
Treatment x Time & 9 & 1.00 & 82.20 & $<0.0001$ \\
\hline
\end{tabular}

$\dagger \mathrm{DF}=$ degrees of freedom, $\mathrm{SS}=$ sums of squares 


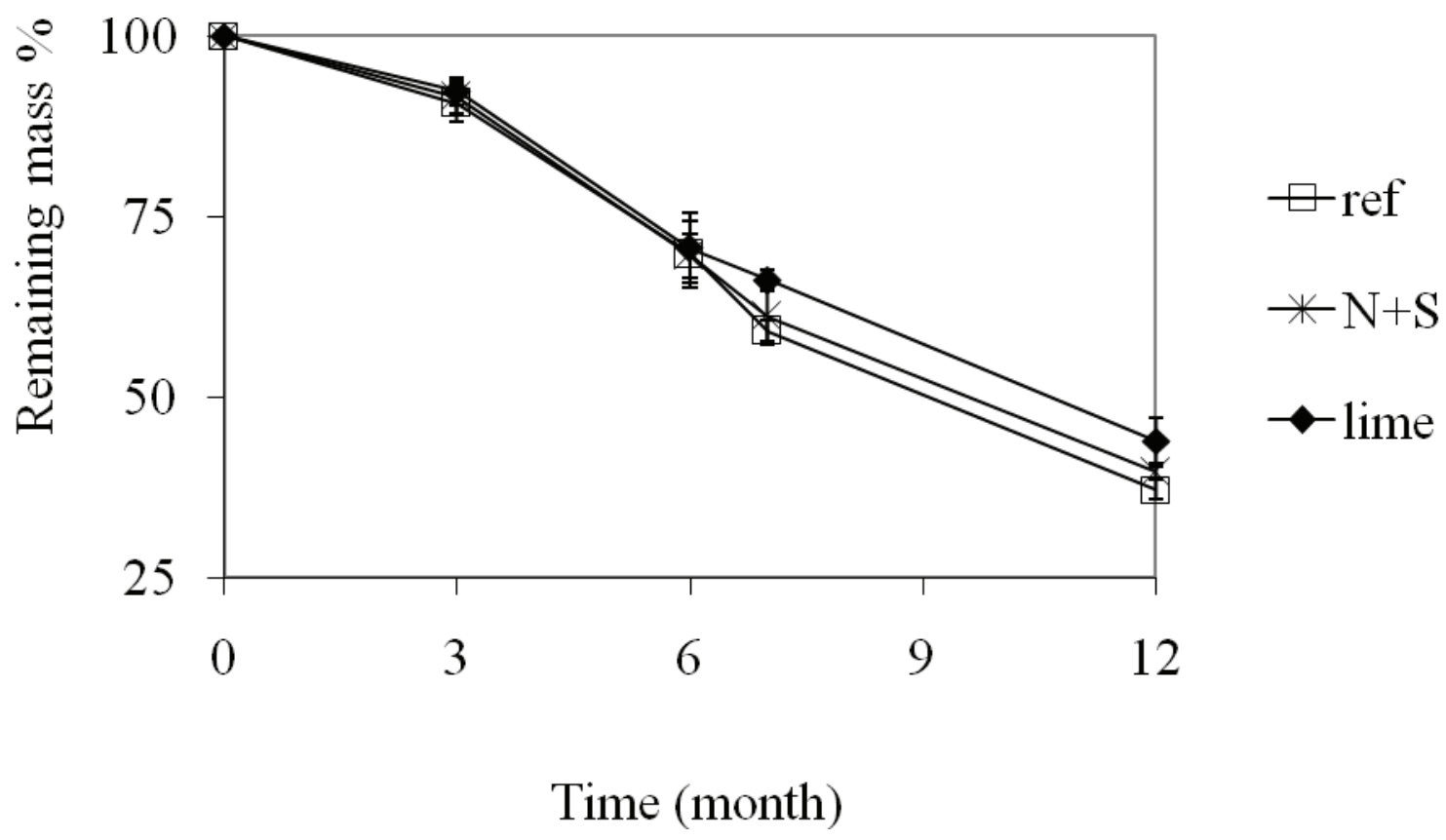

Fig. 1. Remaining mass percentage in leaf litter in reference (ref), lime, and ammonium sulfate $(\mathrm{N}+\mathrm{S})$ treatments over time. 


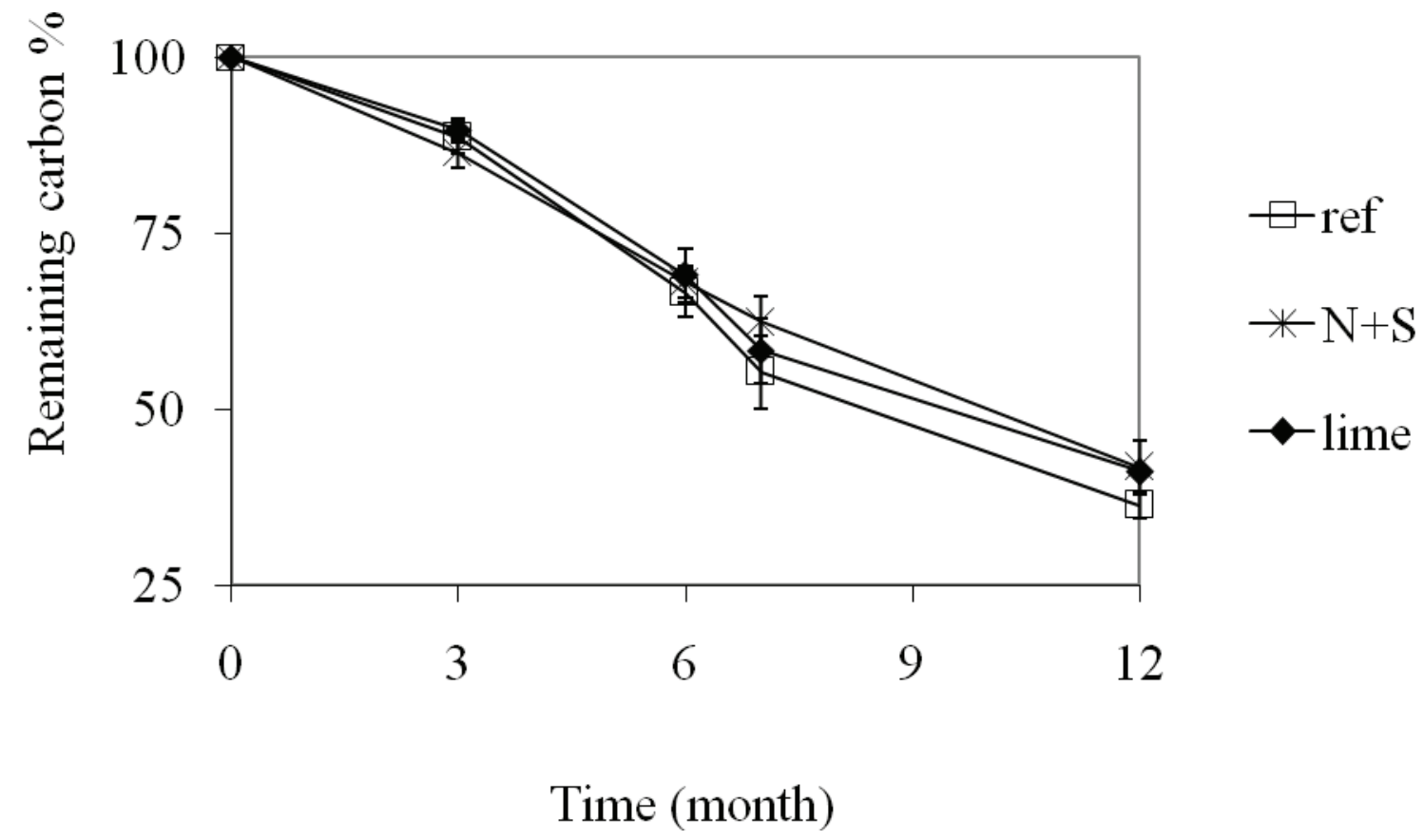

Fig. 2. Remaining carbon percentage in leaf litter in reference (ref), lime, and ammonium sulfate $(\mathrm{N}+\mathrm{S})$ treatments over time 


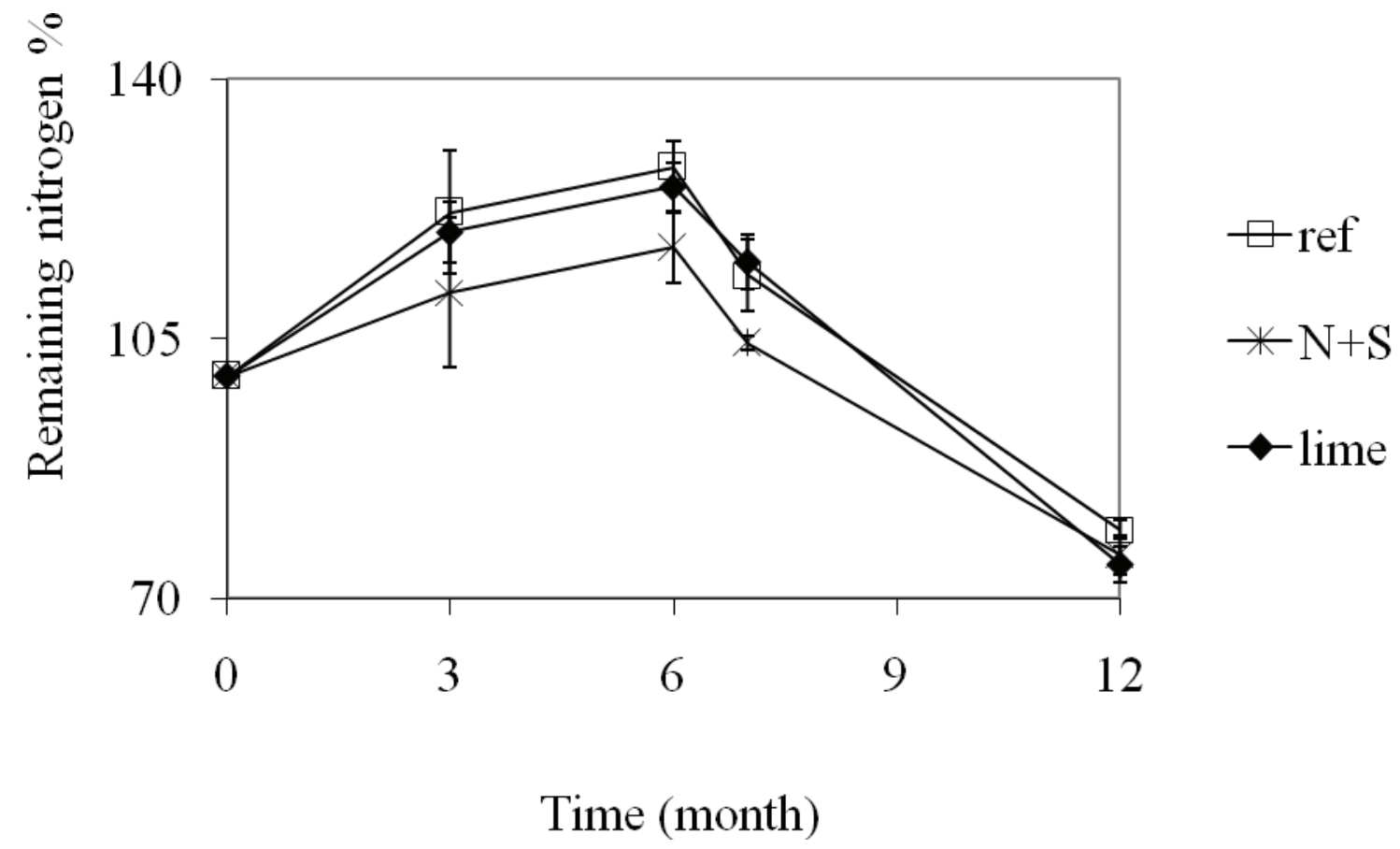

Fig. 3. Remaining nitrogen percentage in leaf litter in the reference (ref), lime, and ammonium sulfate $(\mathrm{N}+\mathrm{S})$ treatments over time 


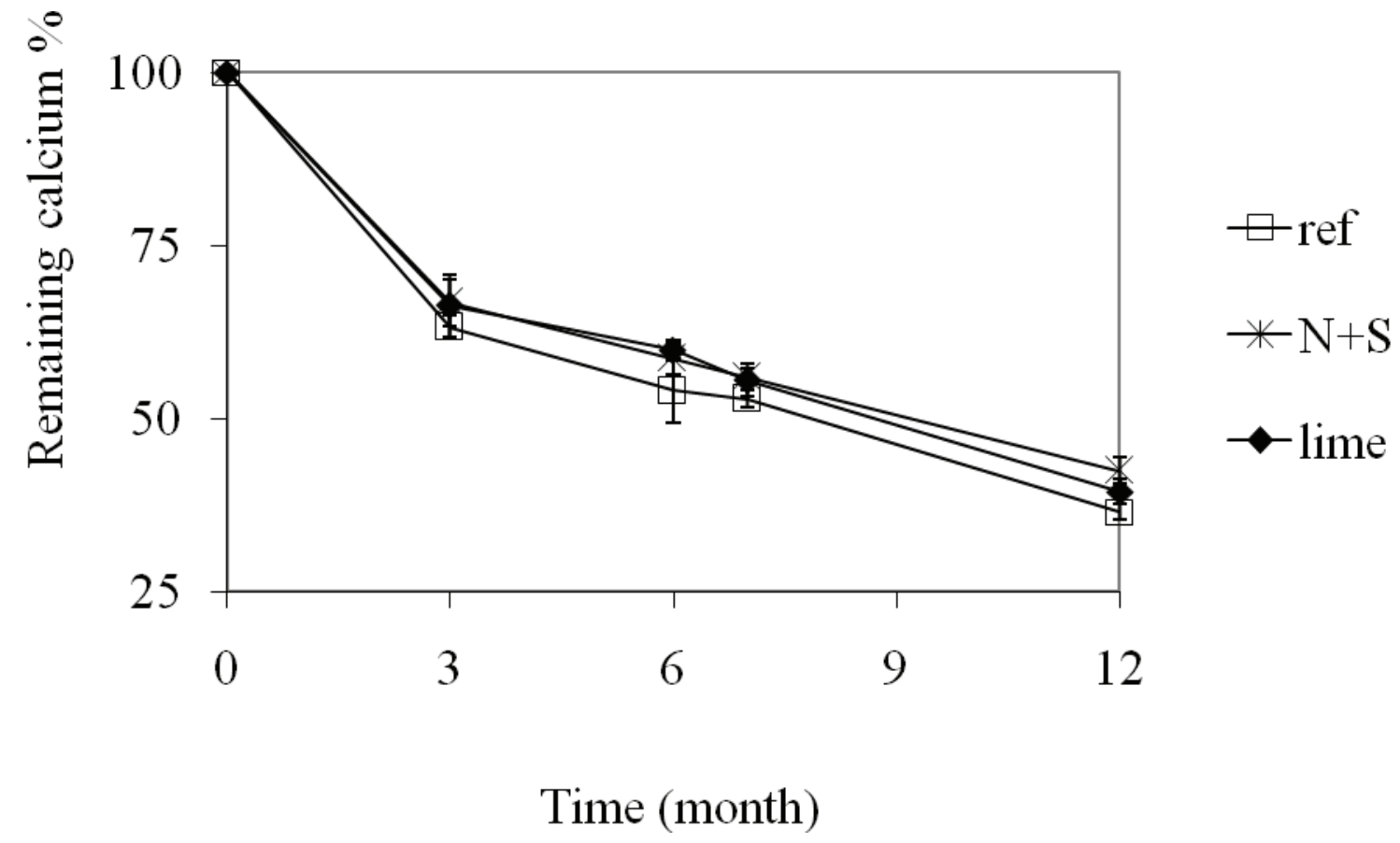

Fig. 4. Remaining calcium percentage in leaf litter in reference (ref), lime, and ammonium sulfate $(\mathrm{N}+\mathrm{S})$ treatments over time 


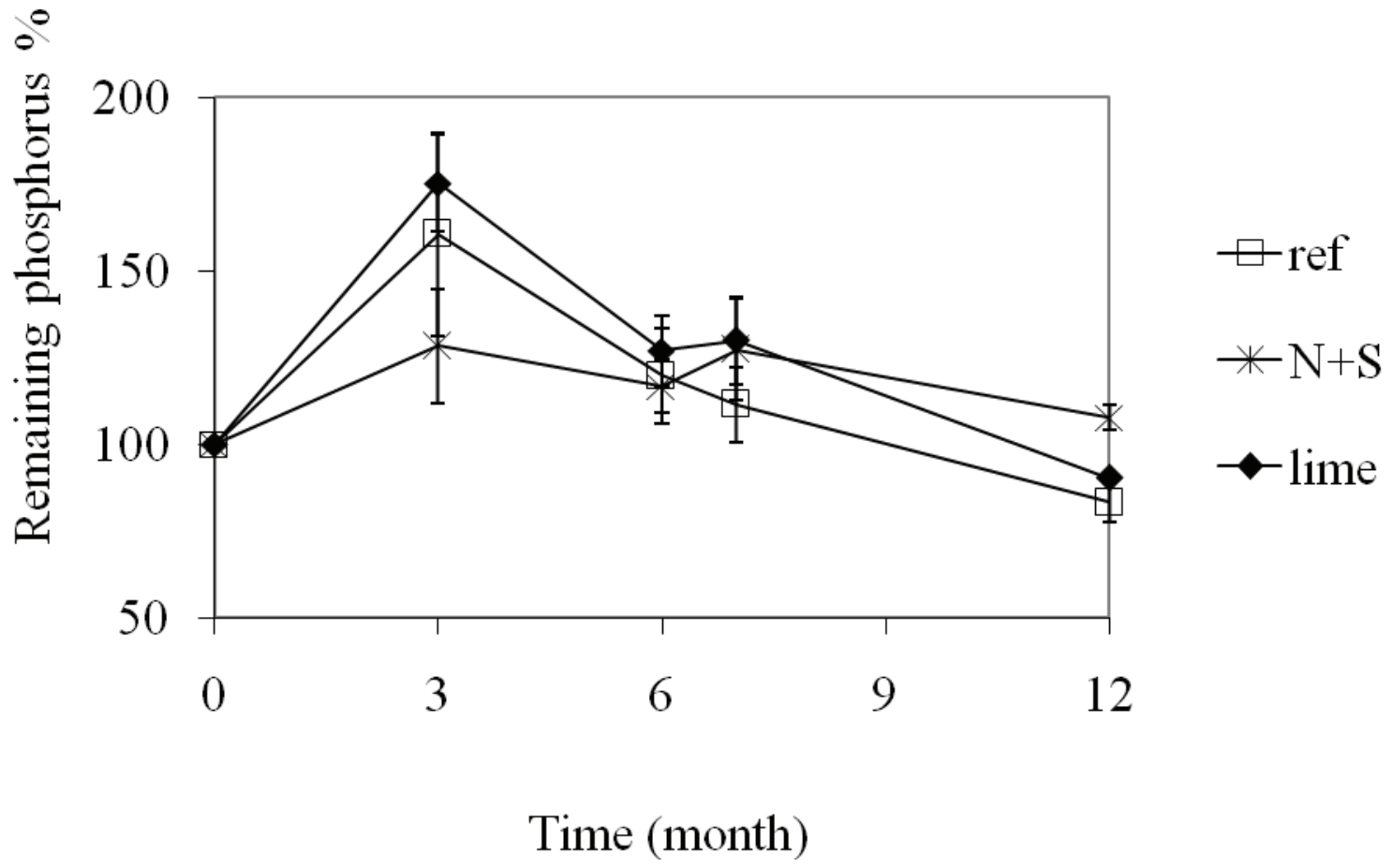

Fig. 5. Remaining phosphorus percentage in leaf litter in reference (ref), lime, and ammonium sulfate $(\mathrm{N}+\mathrm{S})$ treatments over time 


\subsection{References}

Aber, J., K. J. Nadelhoffer, P. Steudler, and J. M. Melillo.1989. Nitrogen saturation in northern forest ecosystems. BioScience 39:378-386.

Aber, J., W. McDowell, K. Nadelhoffer, A. Magill, G. Berntson, M. Kamakea, S. McNulty, W. Currie, L. Rustad and I. Fernandez.1998. Nitrogen saturation in temperate forest ecosystems. BioScience 48:921-934.

Adams, M. B. and T. R. Angradi. 1996. Decomposition and nutrient dynamics of hardwood leaf litter in the Fernow Whole-Watershed Acidification Experiment. For. Ecol. Manage. 83:61-69.

Adams, M. B., T. R. Angradi, and J. N Kochenderfer. 1997. Stream water and soil responses to five years of nitrogen and sulfur additions at the Fernow Experimental Forest, West Virginia. For. Ecol. Manage. 95:79-91.

Adams, M. B., J. A. Burger, A. B. Jenkins, and L. Zelazny. 2000. Impact of harvesting and atmospheric pollution on nutrient depletion of eastern US hardwood forests. For. Ecol. Manage. 138:301-319.

Adams, M. B., J. Burger, L. Zelazny and J. Baumgras. 2004. Description of the Fork Mountain 
Long-term soil productivity study: site characterization. USDA For. Serv. Northeastern Research Station Gen. Tech. Rep. NE-323. 19.

Adams, M. B., J. N. Kochenderfer, and P. J. Edwards. 2007. The Fernow Watershed Acidification Study: Ecosystem Acidification, Nitrogen Saturation and Base Cation Leaching. Water Air Soil Pollut. 7:267-273.

Attiwill, P. M. 1980. Nutrient cycling in a Eucalyptus oblique (L' Herit.) forest. IV Nutrient uptake and nutrient return. Aust. J. Bot. 28:199-222.

Baath, E., A. Frostegtd, T. Pennanen, and H. Fritze. (1995). Microbial community structure and $\mathrm{pH}$ response in relation to soil organic matter quality in wood-ash fertilized, clear-cut or burned coniferous forest soils. Soil Biol. Biochem. 27:229-240

Baker, T. G., and P. M. Attiwill. 1985. Loss of organic matter and elements from decomposing litter of Eucalyptus oblique L' Herit. and Pinus radiata D. Don. Australian For. Res. 15:309-319.

Bates, J. D., T. S. Svejcar, and R. F. Miller. 2007. Litter decomposition in cut and uncut western juniper woodlands. J. Arid Environ. 70:222-236. 
Berg, B., and E. Matzner. 1997. Effect of $\mathrm{N}$ deposition on decomposition of plant litter and soil organic matter in forest systems. Environ. Rev. 5:1-25.

Berg, B. 1986. Nutrient release from litter and humus in coniferous forest soils-a mini review. Scandinavian J. For. Res. 1:359-369.

Berg, B., and G. Ekbohm. 1991. Litter mass-loss rates and decomposition patterns in some needle and leaf litter types. Long-term decomposition in a Scots pine forest. VII. Can. J. Bot. 69:1449-1456.

Bryant, D. M., E. A. Holland, T. R. Seastedt, and M. D. Walker. 1998. Analysis of litter decomposition in an alpine tundra. Can. J. Bot. 76:1295-1304.

Carreiro, M. M., R. L. Sinsabaugh, D. A. Repert, and D. F. Parkhurst. 2000. Microbial enzyme shifts explain litter decay responses to simulated $\mathrm{N}$ deposition. Ecology 81:2359-2365.

Chapman, K., J. B. Whittaker, and O. W. Heal. 1988. Metabolic and faunal activity in litter of tree mixtures compared with pure stands. Agric. Ecosyst. Environ. 24:33-40. 
Federer, C. A., J. W. Hornbeck, L. M. Tritton, C. W. Martin, R. S. Pierce, and C. T. Smith. 1989. Long-term depletion of calcium and other nutrients in eastern US forests. Environ. Manage. 13:593-601.

Fenn, M. E., M. A. Poth, J. D. Aber, J. S. Baron, B. T. Bormann, D. W. Johnson, A. D. Lemly, S. G. McNulty, D. F. Ryan, and R Stottlemeyer. 1998. Nitrogen excess in North American ecosystems: Predisposing factors, ecosystem responses, and management strategies. Ecol. Appl. 8:706-733.

Fog, K. 1988. The effect of added N on the rate of decomposition of organic matter. Biological Review 63:433-462.

Fyles, J. W. and I. H. Fyles. 1993. Interaction of Douglas-fir with red alder and salal foliage litter during decomposition. Can. J. For. Res. 23:358-361.

Gilliam, F. S., M. B. Adams, and B. M. Yurish. 1996. Ecosystem nutrient responses to chronic nitrogen inputs at Fernow Experimental Forest, West Virginia. Can. J. For. Res. 16:196-205.

Gosz, J. R., G. E. Liken, and F. H. Borman. 1973. Nutrient release from decomposing leaf and branch litter in the Hubbard Brook Forest, New Hampshire. Ecological Monographs 43:173191. 
Gress, S. E., T. D. Nichols, C. C. Northcraft, and W. T. Peterjohn. 2007. Nutrient limitation in soils exhibiting differing nitrogen availabilities: What lies beyond nitrogen saturation? Ecology. 88: $119-130$.

Halm, B. J., J. W. B. Stewart, and R. L. Halstead. 1972. The phosphorus cycle in a native grassland ecosystem. In: Isotopes and radiation in soil-plant relationships, including forestry. Vienna: International Atomic Energy Agency 571-586.

Helvey, J. D. and S. H. Kunkle. 1986. Input-out budgets of selected nutrients on an experimental watershed near Parsons, West Virginia. Res. Pap. NE-584. Broomall, PA: USDA For. Serv. Northeastern Forest Experiment Station. 7p.

Hobbie, S. E. 2000. Interactions between litter lignin and soil nitrogen availability during leaf litter decomposition in a Hawaiian Montane Forest. Ecosystems 3:484-494.

Hobbie, S. E., and P. M. Vitousek. 2000. Nutrient limitation of decomposition in Hawaiian forests. Ecology 81:1867-1877. 
Hunt, H. W., E. R. Ingham, D. C. Coleman, E. T. Elliot, and C. P. P. Reid. 1988. N limitation of production and decomposition in prairie, mountain meadow, and pine forest. Ecology 69:10091016.

Ito, M., M. J. Mitchell, and C. T. Driscoll. 2002. Spatial patterns of precipitation quantity and chemistry and air temperature in the Adirondack region of New York. Atmos. Environ. 36:10511062.

Keyser, P., T. K. Kirk, and I. G. Zeikus. 1978. Lignolytic enzyme system of Phanerochaete chrysosporium: synthesized in the absence of lignin in response to nitrogen starvation. J. Bacteriol. 135:790-7.

Knorr, M., S. D. Frey, and P. S. Curtis. 2005. Nitrogen additions and litter decomposition: A meta analysis. Ecology 86:3252-3257.

Magill, A. H., and J. D. Aber. 1998. Long-term effects of experimental N additions on foliar litter decay and humus formation in forest ecosystems. Plant Soil 203:301-311. 
Mann, L. K., D. W. Johnson, D. C. West, D. W. Cole, J. W. Hornbeck, C. W. Martin, H. Riekerk, C. T. Smith, W. T. Swank, L. M. Tritton, and D. H. van Lear. 1988. Effects of wholetree and stem-only clearcutting on postharvest hydrologic losses, nutrient capital and regrowth. For. Sci. 34:412-428.

Marschner, B. and A. W. Wilczynski. 1991. The effect of liming on quantity and chemical composition of soil organic matter in a pine forest in Berlin, Germany. Plant Soil 137:229-236.

McClaugherty, C., and B. Berg. 1987. Cellulose, lignin, and N concentrations as rate regulating factors in late stages of forest litter decomposition. Pedobiologia 30:101-112.

Miller, H. G., J. M. Cooper, J. D. Miller and O. J. L. Pauline. 1979. Nutrient cycles in pine and their adaptation to poor soils. Can Journal of Botany 9:19-26.

Nihlgard, B.1985. The ammonium hypothesis, an additional explanation to the forest dieback in Europe. Ambio 14:2-8.

O’Connell, A. M. 1988. Nutrient Dynamics in decomposing litter in karri (Eucalyptus diversicolor F. Muell) forests of south western Australia. J. Ecol. 76:1186-1203. 
Olson, J. S. 1963. Energy storage and the balance of producers and decomposers in ecological systems. Ecology 44:322-331.

Pastor, J., M. A.Stillwell, and D. Tilman. 1987. Little blue stem litter dynamics in Minnesota old fields. Oecologia 72:327-330.

Peterjohn, W. M., M. B. Adams, and F. S. Gilliam. 1996. Symptoms of nitrogen saturation in two central Appalachian hardwood forest ecosystems. Biogeochemistry 35:507-522.

Piatek, K. B. and H. L. Allen. 2001. Are forest floors in mid-rotation stands of loblolly pine (Pinus taeda) a sink for nitrogen and phosphorus? Can. J. For. Res. 31:1164-1174.

Prescott, C. E. 1995. Does N availability control rates of litter decomposition in forests? Plant Soil 168-169:83-88.

Romkens, P. F., J. Bril, and W. Salomons. 1996. Interactions between $\mathrm{Ca}^{2+}$ and dissolved carbon: implications for metal mobilization. Appl. Geochem. 11:109-115.

Smith, C. T., M. L. J. McCormack, J. W. Hornbeck, and C. W. Martin. 1986. Nutrient and biomass removals from a red spruce-balsam fir whole-tree harvest. Can. J. For. Res. 16:381-388. 
Stoddard, J. L. 1994. Long-term changes in watershed retention of nitrogen: Its causes and consequences. Pages 223-282 In Baker L. A. (Ed). Environmental Chemistry of Lakes and Reservoirs. Am. Chem. Soc. Washington DC.

Taussky, H. H. and E. Shorr. 1953. A microcolorimetric method for the determination of inorganic phosphorus. J. Biol. Chem. 202:675-685.

Vitousek, P. M., J. D. Aber, and R. W. Howarth, G. E. Likens, P. A. Matson, D. W. Schindler, W. H. Schlesinger and D. G. Tilman. 1997. Human alteration of the global nitrogen cycle: sources and consequences. Ecol. Applic. 7:737-750. 


\section{STUDY 2}

\subsection{Effects of single-mixed leaf litters and Atmospheric Acid Deposition on Mass loss, C, N, P and, Ca dynamics of Quercus rubra in a regenerating forest \\ 3.1 ABSTRACT}

To understand the impacts of acid deposition on decomposition of single- and mixedspecies litters, we conducted a litter bag experiment under twice ambient rates of acid deposition $(\mathrm{N}+\mathrm{S})$ and compared to a reference (no additions), and ammonium sulfate plus lime additions (lime). The study was conducted at the Fernow Experimental Forest (FEF) in West Virginia. Mass loss and nutrient dynamics $(\mathrm{C}, \mathrm{N}, \mathrm{P}$, and $\mathrm{Ca}$ ) were quantified in oak decomposing alone (Oak), oak decomposing with maple (Oak+), and oak decomposing with maple, yellow poplar, magnolia, cherry and birch $(\mathrm{Oak}++)$ over a 12-month period. At 12 months, the remaining mass of oak was significantly lower in the reference (ref) plots (50\%) than in the N+S (54\%) and lime $(55 \%)$ treatments $(p<0.0001)$. The decay constant $(k)$ was significantly higher in Oak++ $(0.682)$ than in Oak+ $(0.614)$ and in Oak $(0.595)(\mathrm{p}<0.0030)$. Throughout the 12 months of decomposition, $\mathrm{N}$ and $\mathrm{P}$ were immobilized in Oak, Oak+, and Oak++ litters in all treatments. At 6 months, remaining $\mathrm{N}$ was significantly lower in $\mathrm{N}+\mathrm{S}$ treatment (125\%) than in both reference $(153 \%)$ and in lime treatment $(155 \%)(p<0.0001)$. At 6 months, the remaining $\mathrm{P}$ was significantly higher in the $\mathrm{N}+\mathrm{S}$ treatment $(178 \%)$ than in the reference $(139 \%)$ and in the lime treatment $(152 \%)(p<0.0001, p=0.0075$ respectively $)$. Remaining $\mathrm{Ca}$ was significantly lower at 12 months in the reference plots $(54 \%)$ than in $\mathrm{N}+\mathrm{S}$ treatment $(61 \%)(p=0.0161)$. 
Mass loss of oak was significantly affected by litter mix $(p<0.0001)$. At 12 months, remaining mass of oak was significantly lower in Oak++ (46\%) than in Oak $(53 \%)$ and Oak+ litter (51\%). Direct contact of oak leaf litter with other leaf species (presence of oak leaves in mixed litters), significantly influenced oak decomposition but it had no effect on $\mathrm{C}, \mathrm{N}, \mathrm{P}$ or $\mathrm{Ca}$ dynamics. Acid deposition $(\mathrm{N}+\mathrm{S})$ lowered the rate of oak mass loss, decreased $\mathrm{N}$ immobilization, increased P immobilization, and lowered Ca mineralization. 


\subsection{INTRODUCTION}

Litter decomposition plays a major role in the cycling of nutrients in forested ecosystems. Atmospheric acid deposition, mainly $\mathrm{N}$ effects on litter decomposition is important to study because, excess $\mathrm{N}$ has the potential to alter plant community composition, function of soil microbial communities, and the ability to suppress the activity of lignin degrading fungi (Berg 1986; Fog 1988; Dix and Webster 1995). This may also influence decomposition of leaf litters in mixtures.

Rates of litter decomposition vary among species (Melillo et al. 1982; Taylor et al. 1989). The influence of climate, quality of litter and the surrounding soil conditions on leaf decomposition has been well documented for single species litters (Gartner and Cardon, 2004). Much research has also been devoted to the prediction of behavior of mixed leaf litters, but relatively few studies have looked at the individual components in a given litter mix. This is important because leaf litter does not segregate into individual species in an ecosystem (Gartner and Cardon, 2004), and different leaf species in mixed litters may interact through physical, chemical, and biological processes during decomposition (Staff 1980; Seastedt 1984), for example transfer of nutrients and secondary chemicals among litter types (Chapman et al. 1988; Taylor et al. 1989; Fyles and Fyles 1993; McTiernan et al. 1997; Wardle et al. 1997; Finzi and Canham 1998; Salamanca et al. 1998; Hector et al. 2000). Movement of nutrients across different litter types could be by biological means such as by fungi (McTiernan et al. 1997) or simply by leaching (Fyles and Fyles 1993; McArthur et al. 1994). Nutrients released by higher quality litter can influence more recalcitrant litter in the surroundings (Fyles and Fyles 1993; Briones and Ineson 1996; McTiernan et al. 1997). On the other hand inhibitory compounds such as tannins and phenols released from one type of litter could slow down the decay of adjacent 
litters (Fyles and Fyles 1993; McArthur et al. 1994; Salamanca et al. 1998).

Many of the mixed litter decomposition studies have reported litter decay and nutrient dynamics of a composite sample (Rustad and Cronan 1988; Blair et al. 1990; Rustad 1994; McTiernan et al. 1997). Information on decay and nutrient dynamics of component species in a mix is lacking (Prescott et al. 1999), but it is important because natural mixing of litters could potentially affect nutrient cycling and primary productivity in ecosystems. One of the possible reasons for this lack may be the extensive time needed to sort component litters from a mix.

Oak is an important component of the Appalachian hardwood forest. In parts of the Fernow Experimental forest, WV (latitude $39^{\circ} 04^{\prime} \mathrm{N}$, longitude $79^{\circ} 41^{\prime} \mathrm{W}$ ), oak litter makes up $48 \%$ of the forest floor (Munasinghe et al. unpublished data). Oak litter is lignified (Sinsabaugh et al. 2002), and may result in slower decay and nutrient release during decomposition. In a previous study, we measured litter decomposition and nutrient dynamics in mixed forest floor litter as affected by acid deposition at twice ambient rates (Munasinghe et al. unpublished data); at the end of 12 months, there were significant treatment effects for litter mass loss, C, P and $\mathrm{Ca}$ dynamics.

Climate, litter quality and external $\mathrm{N}$ availability interact to determine litter decay and nutrient cycling (Knorr et al. 2005). Located in the central Appalachian region, the FEF in West Virginia receives about $17 \mathrm{~kg}$ of $\mathrm{N} \mathrm{ha}^{-1} \mathrm{yr}^{-1}$ and about $20 \mathrm{~kg}$ of S ha ${ }^{-1} \mathrm{yr}^{-1}$ through atmospheric deposition (Adams et al. 2000). There is a great concern about the effects of atmospheric acid deposition and its effects on litter decomposition and foliar nutrient dynamics at the FEF. Adams and Angradi (1996) reported that the decay rates of yellow poplar, red maple, black cherry, or black birch did not differ in WS3 or WS7 watersheds at the FEF. In another study at the FEF, May et al. (2005) reported differences in the tree growth and plant nutrition responses under 
increasing N saturation in WS3 and WS7 watersheds. As $48 \%$ of the forest litter floor at the FEF contained red oak, we were interested in looking at the decomposition and nutrient dynamics of oak with the objectives of: 1 . determining the effects of atmospheric deposition and the role of lime on the decomposition and nutrient dynamics of oak leaf litter, and 2. establishing whether these effects differ when oak decomposes in the presence of other leaf litter mixes. 


\subsection{MATERIALS AND METHODS}

\subsubsection{Study site}

We conducted the experiment in the Long Term Soil Productivity Study (LTSP) located at the Fernow Experimental Forest (FEF) in Tucker County, West Virginia (latitude $39^{\circ} 04^{\prime} \mathrm{N}$, longitude $79^{\circ} 41^{\prime} \mathrm{W}$ ) on Fork Mountain (Adams et al. 2004). The site has a southeast aspect and the elevation ranges from $798 \mathrm{~m}$ to $847 \mathrm{~m}$. Land slope ranges from 15 to 31 percent (Adams et al. 2004). The LTSP experiment was established in 1996 with three objectives, 1) to characterize the productivity, diversity and biogeochemistry of a forest system under conditions of simulated atmospheric deposition, 2) to determine the response of the forest ecosystem to base cation removal, and 3) to modify the existing vegetation/nutrient/hydrologic models to describe and simulate forest changes due to base removals and acidic deposition (Adams et al. 2004). The LTSP experiment has four treatments established in four blocks at different slope positions: 1) uncut untreated control, 2) whole-tree harvesting, 3) whole tree harvesting plus ammonium sulfate additions, and 4) whole tree harvesting plus ammonium sulfate and dolomitic lime addition. Each experimental plot is 0.2 ha in size with a $7.6 \mathrm{~m}$ wide buffer strip (Adams et al. 2004). For our study we used three treatments: 1) whole tree harvesting (ref), 2) whole tree harvest + ammonium sulfate additions $(\mathrm{N}+\mathrm{S})$ and 3) whole tree harvesting plus ammonium sulfate and dolomitic lime addition (lime). The uncut untreated control was not used in our study. A total of 12 experimental plots ( 4 replicates per treatment) were used for this study. The $\mathrm{N}+\mathrm{S}$ treatment was designed to simulate acid deposition at twice the ambient rate in order to accelerate cation leaching from the soil. In the early 1980's, ambient atmospheric deposition

rates of through fall $\mathrm{N}$ and $\mathrm{S}$ in this region were $\sim 15$ and $17 \mathrm{~kg} \mathrm{ha}^{-1} \mathrm{yr}^{-1}$ respectively (Helvey and 
Kunkle 1986), therefore $36 \mathrm{~kg} \mathrm{~N}$ and $40 \mathrm{~kg} \mathrm{Sha}^{-1}$ are added annually with the ammonium sulfate treatment. Enhanced deposition is applied three times a year in March, July and November. In March and November $34 \mathrm{~kg}$ of ammonium sulfate is applied ha ${ }^{-1}\left(7.1 \mathrm{~kg} \mathrm{~N} \mathrm{ha}^{-1}\right.$ and $8.1 \mathrm{~kg} \mathrm{~S}^{-}{ }^{-}$ ${ }^{1}$ ), while in July $101 \mathrm{~kg}$ of ammonium sulfate is applied $\mathrm{ha}^{-1}\left(21.3 \mathrm{~kg} \mathrm{~N} \mathrm{ha}^{-1}\right.$ and $\left.24.4 \mathrm{~kg} \mathrm{~S} \mathrm{ha}^{-1}\right)$ (Adams et al. 2007). Stream water exports of $\mathrm{Ca}$ and $\mathrm{Mg}$ at the FEF for an untreated mature forested watershed (WS4) are about 11.25 and $5.83 \mathrm{~kg} \mathrm{ha}^{-1} \mathrm{yr}^{-1}$, respectively (Adams et al. 1997). Dolomitic lime is added every other year in March at a rate twice that of stream water exports of $\mathrm{Ca}$ at the experimental site.

\subsubsection{Foliar litter collection and litter bag preparation}

Foliar litter was collected from each treatment plot from the top litter layer in December 2005. Leaves were separated by species from individual plots and were pooled by treatment into northern red oak (Quercus rubra), maple (Acer rubrum and A.saccharum), yellow poplar (Liriodendron tulipifera), magnolia (Magnolia acuminata, and M. fraserii), sweet birch (Betula lenta) and cherry (Prunus serotina, and P. pennsylvanica). Collected leaf litter was allowed to air dry for 10 days. Three different litter bag types were made: oak leaves only (pure Oak), 50\% oak and 50\% maple leaves, and the ambient litter mix with $48 \%$ oak, $19 \%$ poplar, $14 \%$ maple, $12 \%$ magnolia, $4 \%$ cherry, and 3\% sweet birch. Litter bags were made of nylon with $2 \mathrm{~mm}$ mesh size and dimensions of $25 \times 22 \mathrm{~cm}$. Approximately $10 \mathrm{~g}$ (total weight) of air-dried leaf litter was placed in each litter bag. Three sub samples ( $2-3 \mathrm{~g})$ of oak, maple, poplar, magnolia, birch, and cherry leaves from each litter mix were oven-dried at $65^{\circ} \mathrm{C}$ for 48 hours to determine their ovendry weights. The difference between oven-dry and air-dry weight was used to calculate litter moisture content. Oven-dry weights of oak, maple, poplar, magnolia, cherry, and birch litter in 
litter bags were estimated using the corresponding moisture contents of each litter type.

\subsubsection{Litter bag placement and collections}

Ten litter bags per litter type (30 total) were placed in a random fashion in each experimental plot (12 total) after snowmelt in March 2006. Litter bags were placed on the mineral soil and held in place with landscape pins. Two bags from each litter type were retrieved from each plot 3, 6, 7 and 12 months after placement in the experiment site. The 7 month collection was made to better detect the switch from nutrient immobilization to mineralization, expected around month 6 of decomposition in these systems (Adams and Angradi, 1996).

\subsubsection{Nutrient Analysis and mass loss measurements}

In the laboratory collected litter bags were manually cleaned off debris. Partially decomposed leaves in mixed litters were separated into oak and other species within one week of collection. Leaves were dried in the oven for 48 hours at $65^{\circ} \mathrm{C}$ and weighed to the nearest hundredth gram. Mass loss over time $(w)$ was calculated using the following formula.

$w=\frac{\left(W_{o}-W_{t}\right)}{W_{0}} \times 100$, where

$W_{0}=$ initial oven-dry mass of oak litter in each litter type

$W_{t}=$ oven-dry mass of oak litter remaining in each litter type at time $\mathrm{t}$

Litter decomposition rate (decay constant k) for oak leaves for each litter type was estimated from an exponential decay model (Olson, 1963): 


$$
\begin{aligned}
& W_{t} / W_{0}=e^{-k t} \\
& k=\text { decay constant }
\end{aligned}
$$

Oven-dried litter was ground on a Wiley mill (60 mesh). The Willey mill was vacuumcleaned between samples. Ground oak litter was re-dried, and 0.3 to 0.5 grams were weighed into tin capsules $(0.009 \times 0.005 \mathrm{~m})$, peletted, and analyzed for total carbon and nitrogen on a Carlo Erba 1500 CNS elemental analyzer with a Micro Dumas Combustion procedure. For the digestion 0.2 grams of ground oak litter was digested in $5 \mathrm{ml}$ of concentrated nitric acid and $30 \%$ hydrogen peroxide at $125^{\circ} \mathrm{C}$ on a digestion block for 5 to 7 hours when they appeared colorless. The volume of digest was made up to $75 \mathrm{ml}$ with deionized water and filtered using $0.45 \mu \mathrm{m}$ nylon filter papers. Aliquots from the filtrate were analyzed for total calcium using a Varian Spectra 220 atomic absorption spectrophotometer at $225 \mathrm{~nm}$ wave length using Nitrous oxide/acetylene gas. Total phosphorus was measured using UV spectrophotometer (VIS spectrophotometer/ Shimadzu, UV 160U, Japan). Nutrient contents of oak in each litter type (c) were estimated by the following formula:

$c=W_{0} * E_{0}$, where

$W_{0}=$ initial oven-dry weight of oak litter

$E_{0}=$ initial elemental concentrations of $\mathrm{C}, \mathrm{N}, \mathrm{P}$, or Ca in oak litter

Remaining content (r) of $\mathrm{C}, \mathrm{N}, \mathrm{P}$, or $\mathrm{Ca}$ were estimated using the following equation: $r=\frac{\left(W_{t} * E_{t}\right)}{\left(W_{0} * E_{0}\right)} * 100$, where 
$\mathrm{W}_{0}$ and $\mathrm{E}_{0}$ as above, and

$W_{t}=$ oven-dry weights of oak litter at a given time $\mathrm{t}$

$E_{t}=$ elemental concentrations of $\mathrm{C}, \mathrm{N}, \mathrm{P}$, or $\mathrm{Ca}$ in oak at a given time $\mathrm{t}$

\subsubsection{Statistical Analysis}

The effects of treatments and single versus mixed litter types on oak (pure Oak, Oak+, and $\mathrm{Oak}++$ ) decomposition, and on $\mathrm{C}, \mathrm{N}, \mathrm{P}$, and $\mathrm{Ca}$ dynamics were analyzed using SAS software (2001 SAS). Normal distribution of observed responses was checked with the UNIVARIATE procedure. Pair-wise comparisons for significant differences between main effects and interaction effects were carried out using TUKEY test pair-wise comparison, where it compares least square means of all possible pairs of factors. A significance level of alpha $=0.05$ was considered.

In our discussion, the effects of treatments, and treatment * litter type interaction on oak (pure Oak, Oak+, and Oak++) mass loss, and C, N, P, and Ca dynamics were drawn from the whole data set including all 3 treatments. The comparison of single/mixed litter type effects on oak mass loss, and C, N, P, and Ca dynamics was drawn only by looking at pure Oak, Oak+ and Oak ++ in the reference plots thereby we removed the potentially confounding effects of treatments. The following statistical model was applied for with the GLM procedure.

$\mathrm{Y}_{\mathrm{ijkl}}=\mathrm{T}_{\mathrm{i}}+\mathrm{M}_{\mathrm{j}}+\mathrm{P}_{\mathrm{k}}+(\mathrm{TM})_{\mathrm{ij}}+(\mathrm{TP})_{\mathrm{ik}}+(\mathrm{MP})_{\mathrm{jk}}+\mathrm{e}_{\mathrm{ijkl}}$

$\mathrm{Y}_{\mathrm{ijkl}}=$ Observed response of $\mathrm{t}^{\text {th }}$ replicate in $\mathrm{j}^{\text {th }}$ oak litter in $\mathrm{i}^{\text {th }}$ treatment at $\mathrm{k}^{\text {th }}$ time 
where;

$\mu=$ Mean response

$\mathrm{T}_{\mathrm{i}}=$ Fixed effect of $\mathrm{i}^{\text {th }}$ treatments $(\mathrm{i}=$ reference, $\mathrm{N}+\mathrm{S}$, and lime)

$1=$ Fixed effect of $1^{\text {th }}$ replicate $(1=1,2,3$, and 4$)$

$M_{j}=$ Fixed effect of $j^{\text {th }}$ oak litter in the single/mixed litter types $(j=$ Oak, Oak + and Oak++)

$\mathrm{P}_{\mathrm{k}}=$ Fixed effect of $\mathrm{k}^{\text {th }}$ time $(\mathrm{k}=3,6,7$, and 12 months $)$

$(\mathrm{TM})_{\mathrm{ij}}=$ Fixed effect of interaction between $\mathrm{i}^{\text {th }}$ treatment and $\mathrm{j}^{\text {th }}$ oak litter

$(\mathrm{TP})_{\mathrm{ik}}=$ Fixed effect of interaction between $\mathrm{i}^{\text {th }}$ treatment and $\mathrm{k}^{\text {th }}$ time

$(\mathrm{MP})_{\mathrm{jk}}=$ Fixed effect of interaction between $\mathrm{j}^{\text {th }}$ oak litter and $\mathrm{k}^{\text {th }}$ time

$(\mathrm{TMP})_{\mathrm{ijk}}=$ Fixed effect of interaction among $\mathrm{i}^{\text {th }}$ treatment, $\mathrm{j}^{\text {th }}$ mix, and $\mathrm{k}^{\text {th }}$ time

$\mathrm{e}_{\mathrm{ijkl}}=$ Random error effect 


\subsection{RESULTS}

\subsubsection{Initial litter characteristics}

Initial oak litter nutrient concentrations $(C, N, P$, and $\mathrm{Ca})$ and $\mathrm{C}$ : nutrient ratios $(\mathrm{C}: \mathrm{N}$, $\mathrm{C}: \mathrm{Ca}$, and $\mathrm{C}: \mathrm{P}$ ) did not significantly differ among treatments (Table 1).

\subsubsection{Single-mixed litter type effects on oak litter mass loss and nutrient dynamics in the reference plots}

There were no significant differences among Oak, Oak+, and Oak++ in mass loss during the first three months, but at 6, 7, and 12 months mass loss was significantly lower in Oak than in Oak $++(p<0.0001)$. (Fig. 1). At 6 months remaining mass was significantly lower in Oak $++(77$ $\%)$ than in Oak decaying alone (83\%). Remaining mass of Oak++ at 7 months $(70 \%)$ and at 12 months (46\%) was also significantly lower than the remaining mass of Oak at 7 months $(77 \%)$ and 12 months $(53 \%)(p<0.0001)$. During the first 7 months remaining mass of Oak + and Oak++ was not significantly different, however by 12 months, remaining mass was significantly lower in Oak++ $(46 \%)$ than in Oak $+(51 \%)(p<0.0001)$. At 3, 6, 7, and at 12 months, the decay rate constant $k$ of Oak was $0.168,0.317,0.392$, and 0.565 respectively while at the same time sequence $\mathrm{k}$ in $0 \mathrm{ak}++$ was $0.241,0.551,0.647$, and 0.739. Decay rate constant $(\mathrm{k})$, after 12 months of decomposition, was significantly lower in Oak $(\mathrm{k}=0.565)$ and in Oak $+(\mathrm{k}=0.586)$ than in Oak $++(\mathrm{k}=0.739)(p<0.0001)$. Throughout the study period $\mathrm{C}, \mathrm{N}, \mathrm{P}$, and $\mathrm{Ca}$ dynamics were not significantly different among Oak, Oak+, or in Oak++. 


\subsubsection{Treatment effects (reference, $\mathrm{N}+\mathrm{S}$, and lime) and treatment * oak litter (Oak, Oak+, and Oak++) interaction effects on decomposition, $C, N, P$, and Ca dynamics.}

There were no significant differences of mass loss in Oak++ within the 3 treatments. (Fig. 2). Similarly up to 7 months, remaining mass of both Oak and Oak+ was not significantly affected by treatments, but by 12 months remaining mass in Oak in the reference (53\%) was significantly lower than in Oak in either of the other two treatments $(57 \%$ in $\mathrm{N}+\mathrm{S}$ and $58 \%$ in lime) $(p=0.0212,0.0420$ respectively). Similarly, the remaining mass of Oak + at 12 months in the reference $(51 \%)$ was significantly lower than that of Oak+ in the lime treatment (59\%) $(p<0.0001)$. The decay rate constants $(k)$ were not significantly different among treatments in

Oak or in $\mathrm{Oak}++$, but at 12 months $\mathrm{k}$ in $\mathrm{Oak}+$ in lime treatment $(\mathrm{k}=0.518)$ was significantly lower than Oak + in the reference $(\mathrm{k}=0.655)(p=0.0016)$. Carbon dynamics in Oak, Oak + , or Oak++ were not significantly different among treatments during the course of decomposition.

Nitrogen was immobilized throughout the study period, irrespective of the treatment or the type of oak litter. Nitrogen immobilization was peaked at 6 months (Fig. 3), where the remaining $\mathrm{N}$ in Oak in the reference $(162 \%)$ was significantly higher $(p=0.0075)$ than the remaining $\mathrm{N}$ in Oak in $\mathrm{N}+\mathrm{S}$ treatment (132\%). Also at 6 months, remaining $\mathrm{N}$ in Oak+ in lime treatment $(161 \%)$ was significantly higher $(\mathrm{p}=0.0003)$ than the remaining $\mathrm{N}$ in Oak + in $\mathrm{N}+\mathrm{S}$ treatment $(125 \%)$. Similarly at 6 months, remaining $\mathrm{N}$ in Oak++ in lime (156\%) and in the reference $(146 \%)$ were significantly higher $(\mathrm{p}<0.0001)$ than the remaining $\mathrm{N}$ in Oak++ in $\mathrm{N}+\mathrm{S}$ treatment (117\%). At the end of 12 months remaining $\mathrm{N}$ in Oak in lime treatment (127\%) was significantly higher than the in Oak in the $\mathrm{N}+\mathrm{S}$ treatment (100\%). 


\subsection{DISCUSSION}

\subsubsection{Mixed litter effects on mass loss and nutrient dynamics of oak litter}

Oak litter decomposed faster when mixed with other litter types than when decomposing alone. This was evident in our decomposition study as Oak showed significantly lower decay rates compared to Oak++ litter, throughout the study. The faster rate of oak decomposition in mixtures indicates that decomposition of oak is stimulated by the presence of poplar, maple, cherry, birch and magnolia leaf litter. Seastedt (1984) hypothesized that nutrient release from rapidly decaying litter types could influence the adjacent recalcitrant litter types, such as oak litter in our study. Decomposition of Oak+ was apparently influenced by maple leaves only up to 7 months. Apparently most of the maple litter in adjacent with Oak + may have decomposed faster during the first 7 months, so that during the latter part of decomposition there was hardly any maple left to influence decay rates in Oak + litter. This would have been the reason for the absence of any significant differences among Oak and Oak+ litter decay, by end of 12 months..

\subsubsection{Acid deposition and lime effects on oak litter decomposition and nutrient dynamics}

Decay rate constants $(k)$ and mass loss of Oak and Oak + in $\mathrm{N}+\mathrm{S}$ and lime treatments at 12 months revealed that acid deposition and lime treatment significantly lowered the rate of oak decay. Many litter studies under experimental $\mathrm{N}$ deposition have reported lowered decay rates (Magill and Aber 1998, Carreiro et al. 2000). Generally, high doses of external N accelerate 
decomposition when plant tissues have low contents of lignin and other recalcitrant compounds, but decelerate decomposition rate when high lignin contents are present (Berg, 1986; Fog, 1988; Berg and Matzner, 1997). In our study excess nitrogen added through N+S and lime treatments would have influenced the resulted lower decomposition in oak litter in comparison to the significantly higher decay rates of oak in reference plots. Additions of $\mathrm{N}$ may inhibit the decomposition of more recalcitrant compounds such as lignin either by suppressing the synthesis of lignolytic enzymes or by influencing the formation of additional recalcitrant compounds, which are highly resistant to biological degradation (Keyser et al., 1978; Berg, 1986; Fog, 1988; Berg and Ekbohm, 1991; Berg and Matzner, 1997).

Nitrogen was immobilized throughout the 12 months of decomposition in all 3 oak litters, with a peak at 6 months. Nitrogen immobilization which is evident in an increase in $\mathrm{N}$ over initial $\mathrm{N}$ content during the initial period of litter decomposition has been observed for different litter types and forests (Berg and Ekbohm 1991; Piatek and Allen 2001; Bates et al. 2007). The occurrence of $\mathrm{N}$ immobilization is indicative of $\mathrm{N}$ limitation to decomposers and also perhaps to forest productivity. In all 3 oak litters (pure Oak, Oak+, and $\mathrm{Oak}++$ ) $\mathrm{N}$ immobilization was higher in the reference compared to $\mathrm{N}+\mathrm{S}$ and lime treatments, though it was not always significant. This would be expected, given that litter-decomposing microorganisms in $\mathrm{N}+\mathrm{S}$ and lime treatments may be less $\mathrm{N}$-limited than microorganisms decomposing oak litter in the reference without added N. Contradicting to this fact, we observed significantly higher $\mathrm{N}$ immobilization in both lime treated Oak + at 6 months and lime treated Oak at 12 months than in the $\mathrm{N}+\mathrm{S}$ treatment. As the lime treatment also receives the same amount of $\mathrm{N}$ as from the $\mathrm{N}+\mathrm{S}$ treatment, we do not have an explanation for the observed results but, lime may stimulate growth 
of microbial biomass by neutralizing acidic conditions of the environment; greater biomass should have higher $\mathrm{N}$ requirements and therefore potentially immobilize more $\mathrm{N}$.

Lower rates of immobilization in the $\mathrm{N}+\mathrm{S}$ treatment translate into lower rates of site $\mathrm{N}$ retention, with increased risk of $\mathrm{N}$ leaching into water courses as nitrate. This has been observed at the Fernow in watersheds 3 and 7; in fact these watersheds leak the most nitrates of any Nsaturated forests in the U.S. (11.8 and $5.5 \mathrm{mg} / \mathrm{kg}$ respectively) (May et al. 2005). This suggest that doubling of the rate of ambient atmospheric $\mathrm{N}$ and $\mathrm{S}$ deposition decreases $\mathrm{N}$ retention in the system by lowering the rate of $\mathrm{N}$ immobilization into oak litter during decomposition.

In our study $\mathrm{P}$ was also immobilized into oak litter during the 12 month of decomposition, similar to $\mathrm{N}$, peak for $\mathrm{P}$ immobilization was also observed at 6 months. Attiwill and Adams (1993) reported that phosphorus is the element which is most likely to be limiting for most of the world's mid-temperate, warm-temperate and tropical forests. In our study, P was immobilized in all Oak, Oak+, and Oak++ litters (Figure 4). Peak for P immobilization in oak litter decomposing alone (Oak) was significantly greater in the acid deposition treatment than in the other treatments. Acid deposition seems to exacerbate P limitation in the forest floor to microbial decomposers, and one possible mechanism may be through the reduction of available forms of $\mathrm{P}$ in the forest floor. This suggests that doubling of the rate of ambient atmospheric acid deposition could further lead to a P-limiting for decomposer communities as well as for tree growth.

In all three treatments $\mathrm{Ca}$ was mineralized during the 12 months of decomposition. During the first 7 months, Ca mineralization in this study was not significantly different among treatments, but at 12 months, both $\mathrm{Oak}^{+}$and $\mathrm{Oak}++$ had significantly more remaining $\mathrm{Ca}$ in the $\mathrm{N}+\mathrm{S}$ treatment than in the reference and lime treatments, suggesting that the rate of $\mathrm{Ca}$ 
mineralization in $\mathrm{N}+\mathrm{S}$ was reduced. This may be related to the lower rate of litter decomposition also observed in our study in the acid deposition treatment.

The ANOVA (Table 4, 5, 6, 7, and 8) for the study 2 showed that the three way interaction of treatment $\mathrm{x}$ oak type $\mathrm{x}$ time was significant. We also saw that the treatments were significant in pure oak litter. It is expected that when time is included in the model that becomes significant as with time mass loss and nutrient dynamics vary significantly. Further more, to look at whether pure oak litter differ from mixed oak litter on decomposition and nutrient dynamics, we also compared oak litter only in the reference plots. 


\subsection{CONCLUSIONS}

Our results further support the literature which shows that leaf litter mixes stimulate oak decay compared to oak decaying alone. Adjacent litter of other species in contact with oak could influence oak decomposition and oak nutrient dynamics. Overall effects of different leaf litter species on oak decomposition and nutrient dynamics in a forest floor composed with $50 \%$ of oak

litter, may affect on decomposer communities and thereby the nutrient release from the forest floor. Gress et al. (2007) reported that under increased atmospheric deposition at the Fernow Experimental Forest, P could become increasingly limiting. Our data also showed that increased P immobilization under simulated acid deposition conditions. Further our data showed that simulated atmospheric acid deposition at thrice the ambient rates may alter oak litter nutrient dynamics by lowering rates of litter decomposition, decreasing $\mathrm{N}$ retention and increasing $\mathrm{P}$ immobilization in a 10-year old regenerating hardwood forest. 
List of tables and figures

Table.1. Initial nutrient concentrations and $\mathrm{C}$ :nutrient ratios in oak litter $(\mathrm{C}, \mathrm{N}$, and $\mathrm{Ca}$ in $\%$ basis and $\mathrm{P}$ in $\mathrm{mg} / \mathrm{kg}$ )

\begin{tabular}{llllllll}
\hline Treatments & $\mathrm{C}$ & $\mathrm{N}$ & $\mathrm{Ca}$ & $\mathrm{P}$ & $\mathrm{C}: \mathrm{N}$ & $\mathrm{C}: \mathrm{Ca}$ & $\mathrm{C}: \mathrm{P}$ \\
\hline Reference & 49 & 0.90 & 1.05 & 481 & 55 & 47 & 1035 \\
Lime & 49 & 0.92 & 1.14 & 480 & 53 & 44 & 1020 \\
$\mathrm{~N}+\mathrm{S}$ & 49 & 1.00 & 0.82 & 431 & 50 & 60 & 1140 \\
\hline
\end{tabular}

$\uparrow$ None of the above parameters are significantly different among treatments

Table.2. Remaining mass of oak litter as a percentage of the initial mass over time, in pure Oak, Oak + and Oak++ litters

\begin{tabular}{lllll}
\hline $\begin{array}{l}\text { Time and } \\
\text { Litter type }\end{array}$ & 3 months & 6 months & 7 months & 12 months \\
\hline Pure Oak & $96.3 \mathrm{a}$ & $83.3 \mathrm{~b}$ & $77.4 \mathrm{~d}$ & $53.3 \mathrm{f}$ \\
Oak + & $96.1 \mathrm{a}$ & $79.9 \mathrm{~b}, \mathrm{c}$ & $73.5 \mathrm{~d}, \mathrm{e}$ & $51.9 \mathrm{f}$ \\
Oak++ & $94.7 \mathrm{a}$ & $77.1 \mathrm{c}$ & $69.9 \mathrm{e}$ & $46.6 \mathrm{~g}$ \\
\hline
\end{tabular}

Table.3. ANOVA table for study 1

\begin{tabular}{lllll}
\hline Sources & DF & SS & F value & Pr $>$ F \\
\hline Treatment & 2 & 0.90 & 14.66 & $<0.0001$ \\
Block & 3 & 0.92 & 2.05 & 0.1259 \\
Treatment $x$ Time & 9 & 1.00 & 82.20 & $<0.0001$ \\
\hline
\end{tabular}

$\dagger \mathrm{DF}=$ degrees of freedom, $\mathrm{SS}=$ sums of squares 
Table.4. ANOVA table for study 2 (Carbon)

\begin{tabular}{llllc}
\hline Sources & DF & SS & F value & Pr $>$ F \\
\hline Treatment & 2 & 76.93 & 2.08 & 0.1306 \\
Oak & 2 & 34.59 & 0.62 & 0.6021 \\
Block & 3 & 354.82 & 9.58 & 0.0002 \\
Time & 3 & 32025.91 & 576.17 & $<0.0001$ \\
Treatment x Oak & 4 & 205.15 & 2.77 & 0.0312 \\
Treatment x Time & 6 & 301.63 & 2.71 & 0.0173 \\
Oak x Time & 6 & 327.19 & 2.94 & 0.0108 \\
Treatment x Oak x Time & 12 & 526.20 & 2.37 & 0.0098 \\
\hline
\end{tabular}

$\dagger \mathrm{DF}=$ degrees of freedom, $\mathrm{SS}=$ sums of squares

Table.5. ANOVA table for study 2 (Mass loss)

\begin{tabular}{lllll}
\hline Sources & DF & SS & F value & Pr $>$ F \\
\hline Treatment & 2 & 71.02 & 13.10 & $<0.0001$ \\
Oak & 2 & 3.46 & 0.43 & 0.7346 \\
Block & 3 & 1435.57 & 264.88 & $<0.0001$ \\
Time & 3 & 32176.28 & 3958 & $<0.0001$ \\
Treatment x Oak & 4 & 132.78 & 12.25 & $<0.0001$ \\
Treatment x Time & 6 & 130.10 & 8.00 & $<0.0001$ \\
Oak x Time & 6 & 377.63 & 23.23 & $<0.0001$ \\
Treatment x Oak x Time & 12 & 62.61 & 1.93 & 0.0393 \\
\hline
\end{tabular}

$\dagger \mathrm{DF}=$ degrees of freedom, $\mathrm{SS}=$ sums of squares 
Table.6. ANOVA table for study 2 (Nitrogen)

\begin{tabular}{lllll}
\hline Sources & DF & SS & F value & Pr $>$ F \\
\hline Treatment & 2 & 6062.14 & 33.9 & $<0.0001$ \\
Oak & 2 & 3207.16 & 17.93 & $<0.0001$ \\
Block & 3 & 1435.57 & 1.36 & $<0.2595$ \\
Time & 3 & 32176.28 & 88.35 & $<0.0001$ \\
Treatment x Oak & 4 & 132.78 & 1.88 & $<0.1202$ \\
Treatment x Time & 6 & 130.10 & 5.21 & $<0.0001$ \\
Oak x Time & 6 & 377.63 & 0.71 & $<0.6399$ \\
Treatment x Oak x Time & 12 & 62.61 & 2.34 & 0.0108 \\
\hline
\end{tabular}

$\dagger \mathrm{DF}=$ degrees of freedom, $\mathrm{SS}=$ sums of squares

Table.7. ANOVA table for study 2, (Phosphorus)

\begin{tabular}{lllll}
\hline Sources & DF & SS & F value & Pr $>F$ \\
\hline Treatment & 2 & 15697.57 & 31.94 & $<0.0001$ \\
Oak & 2 & 1116.17 & 1.51 & 0.2152 \\
Block & 3 & 18246.87 & 37.13 & $<0.2595$ \\
Time & 3 & 25347.63 & 34.39 & $<0.0001$ \\
Treatment x Oak & 4 & 13831.35 & 14.07 & $<0.1202$ \\
Treatment x Time & 6 & 2559.55 & 1.74 & 0.1199 \\
Oak x Time & 6 & 4012.58 & 2.72 & $<0.0170$ \\
Treatment x Oak x Time & 12 & 5410.20 & 1.83 & 0.0518 \\
\hline
\end{tabular}

$\dagger \mathrm{DF}=$ degrees of freedom, $\mathrm{SS}=$ sums of squares 
Table.8. ANOVA table for study 2, Calcium (Ca)

\begin{tabular}{lllll}
\hline Sources & DF & SS & F value & Pr $>$ F \\
\hline Treatment & 2 & 57.66 & 1.43 & 0.2439 \\
Oak & 2 & 1447.86 & 35.92 & $<0.0001$ \\
Block & 3 & 91.39 & 1.51 & 0.2159. \\
Time & 3 & 9666.03 & 159.86 & $<0.0001$ \\
Treatment x Oak & 4 & 449.64 & 5.58 & 0.0004 \\
Treatment x Time & 6 & 374.66 & 3.10 & 0.0078 \\
Oak x Time & 6 & 200.75 & 1.66 & 0.1382 \\
Treatment x Oak x Time & 12 & 850.66 & 3.52 & 0.0002 \\
\hline
\end{tabular}

$\dagger \mathrm{DF}=$ degrees of freedom, $\mathrm{SS}=$ sums of squares 


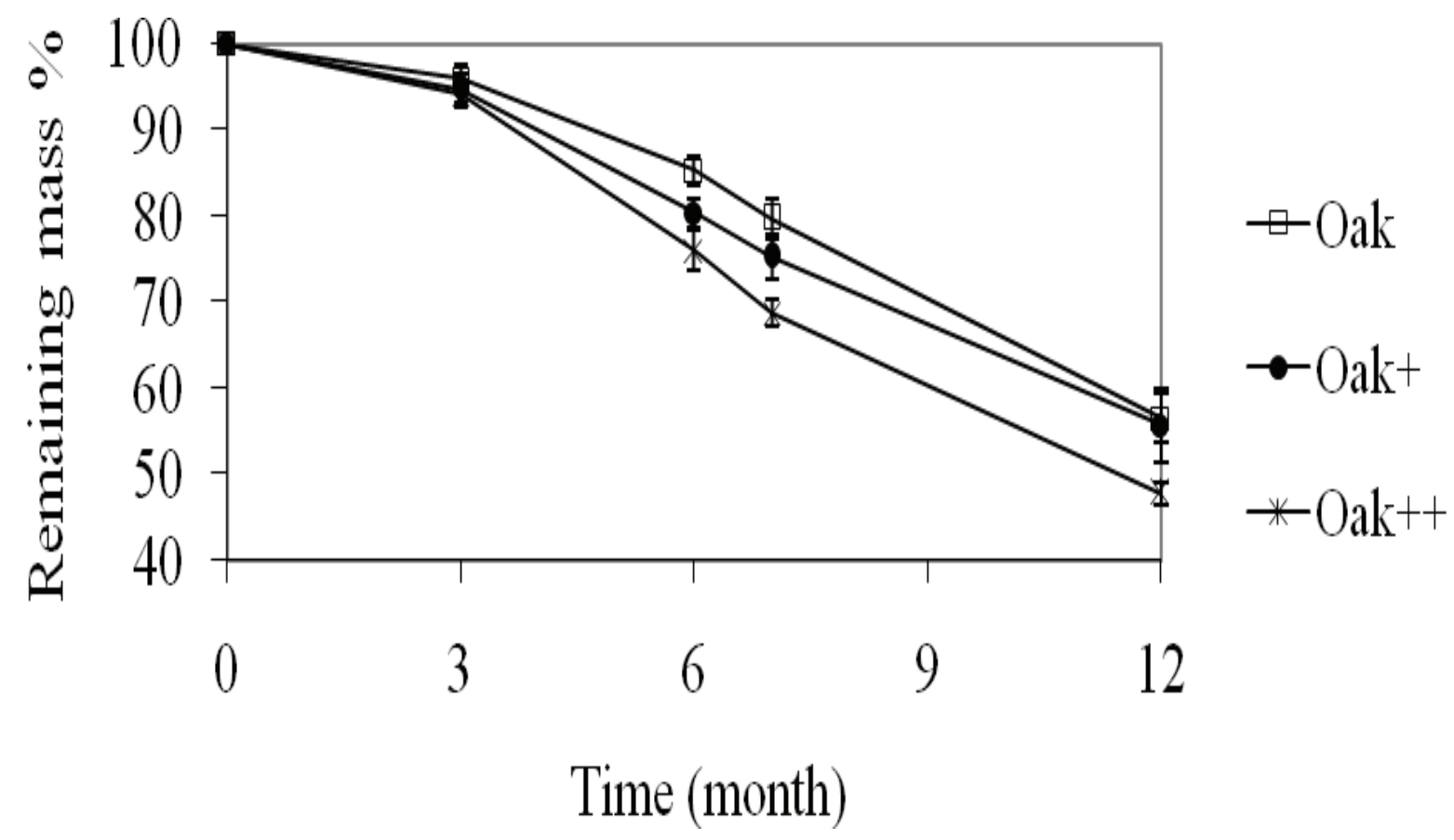

Fig. 1. Comparison of Significant differences observed for mass loss dynamics in oak litter in pure oak litter (pure Oak), oak/maple litter $\left(\mathrm{Oak}^{+}\right)$and oak in ambient litter mix (Oak++) in reference plots over time. 


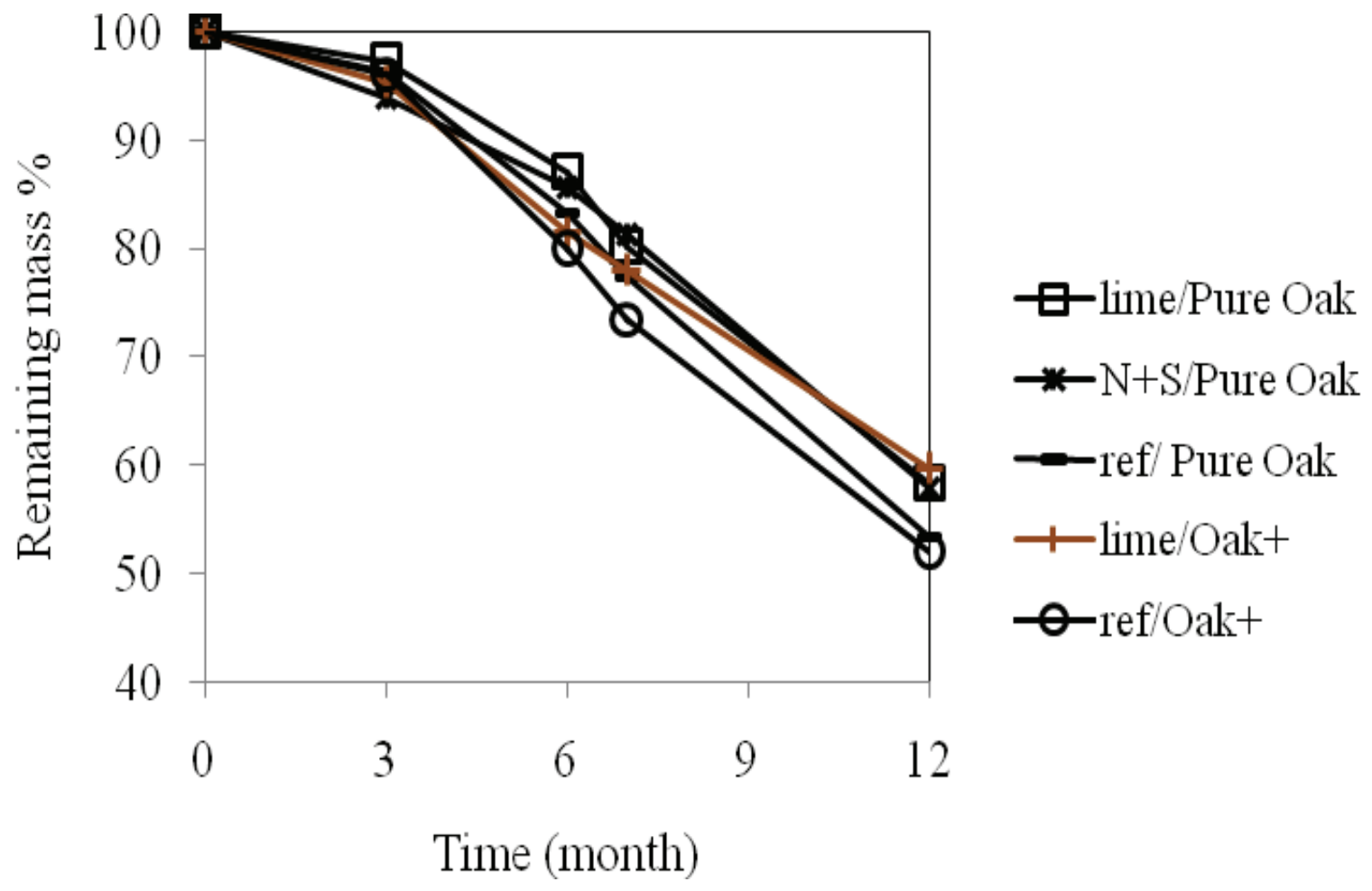

Fig. 2. Comparison of Significant differences observed at 12 months in mass loss dynamics in Oak litter in reference, $\mathrm{N}+\mathrm{S}$, and lime treatments and mass loss dynamics in Oak+ litter in reference and lime treatments over time. 


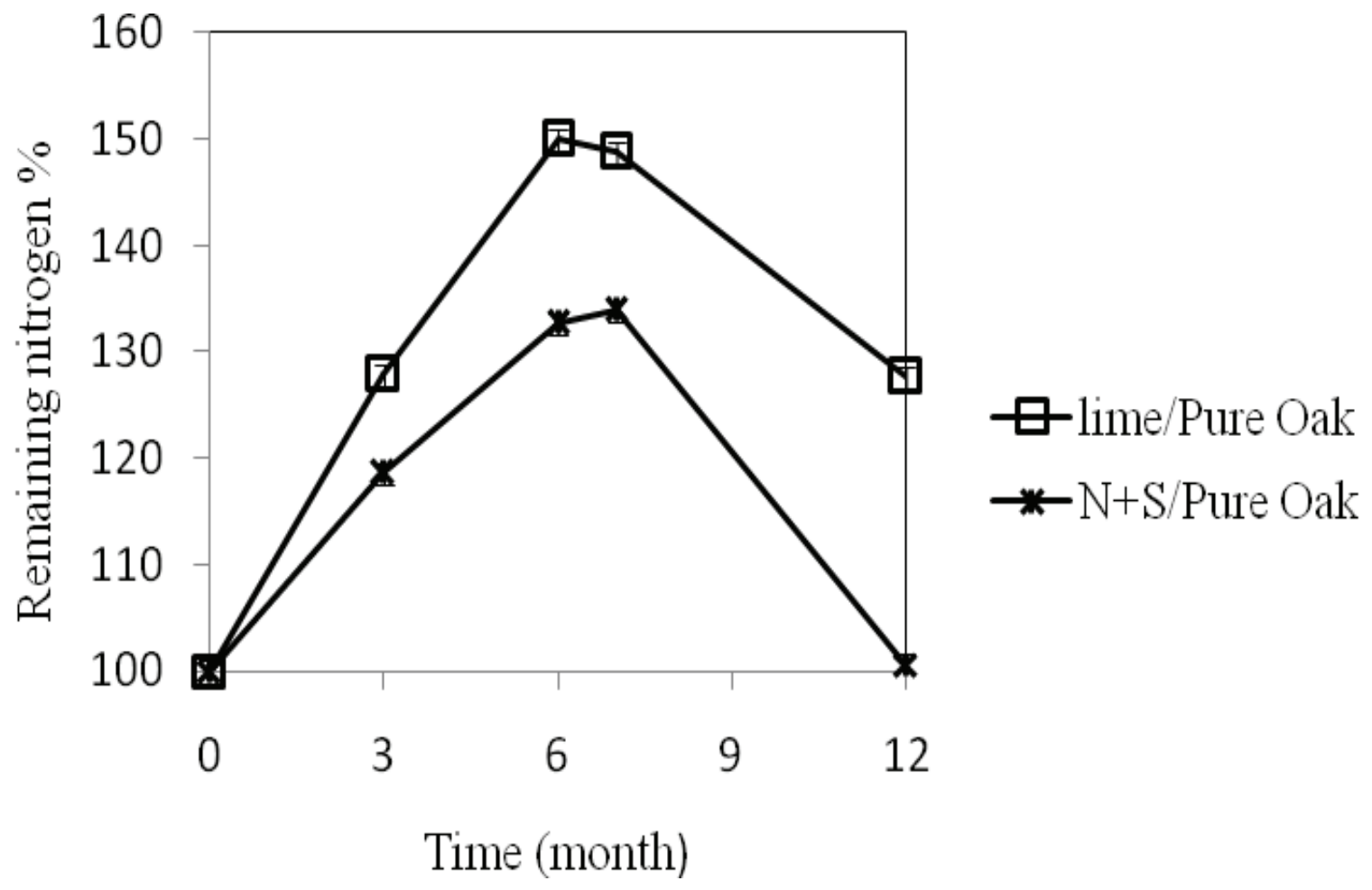

Fig. 3. Nitrogen dynamics in pure Oak litter in $\mathrm{N}+\mathrm{S}$ and lime treatments over time (Oak+ and Oak++ litter did not show any significant differences for treatments, therefore not displayed in the graph). 


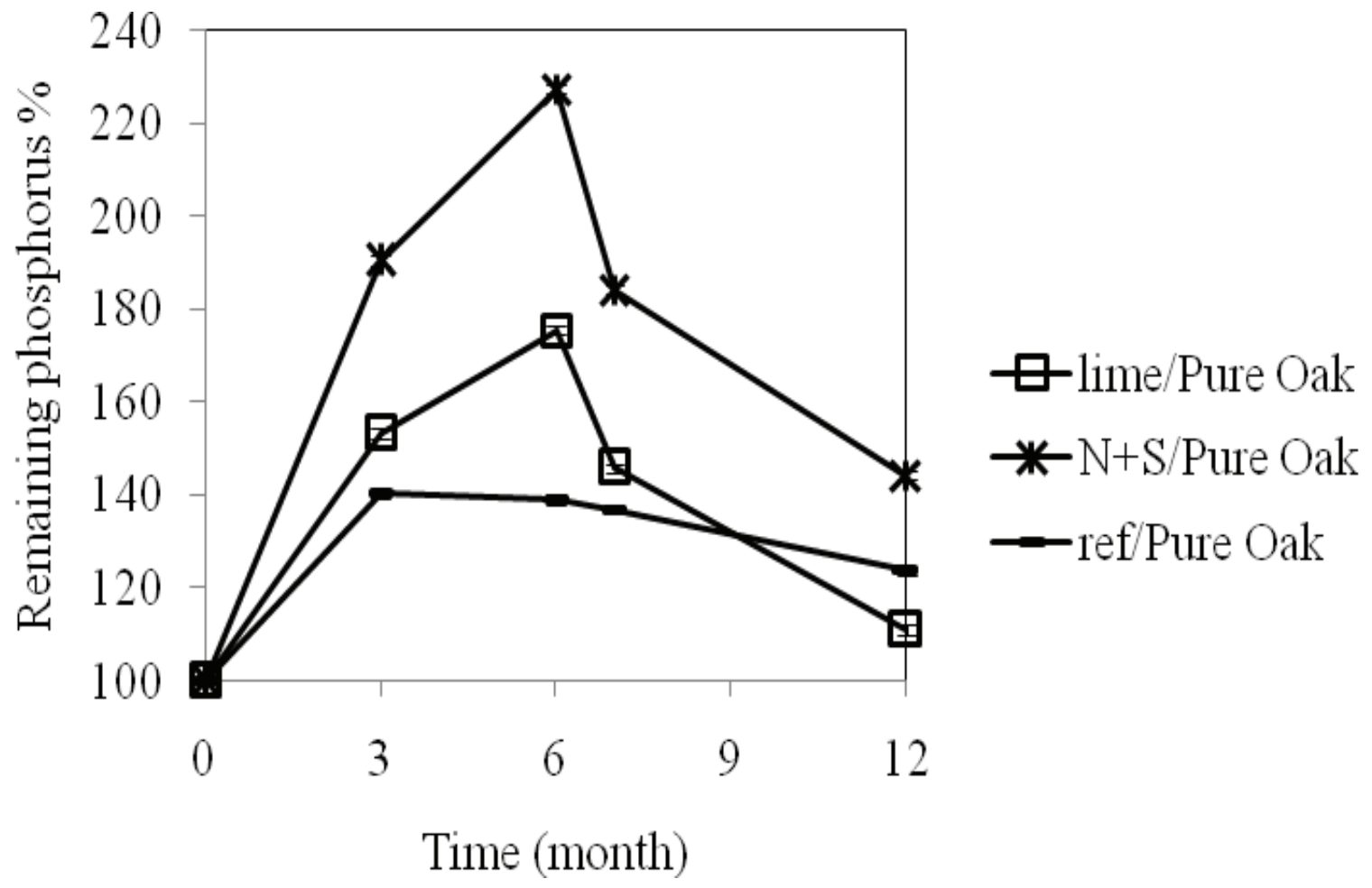

Fig. 4. Phosphorus dynamics in pure Oak litter in the reference plots, $\mathrm{N}+\mathrm{S}$, and lime treatments over time $\left(\mathrm{Oak}^{+}\right.$and $\mathrm{Oak}++$ litter did not show any significant differences for treatments, therefore not displayed in the graph). 


\subsection{References}

Adams, M. B. and T. R. Angradi. 1996. Decomposition and nutrient dynamics of hardwood leaf litter in the Fernow Whole-Watershed Acidification Experiment. Forest Ecology and Management. 83:61-69.

Adams, M. B., J. Burger, L. Zelazny and J. Baumgras. 2004. Description of the Fork Mountain Long-term soil productivity study: site characterization. USDA For. Serv. Northeastern Research Station Gen. Tech. Rep. NE-323. 19.

Adams, M. B., J. N. Kochenderfer, and P. J. Edwards. 2007. The Fernow Watershed Acidification Study: Ecosystem Acidification, Nitrogen Saturation and Base Cation Leaching. Water Air Soil Pollut. 7:267-273.

Attiwill, P. M. and M. B. Adams. 1993. "Tansley Review” No. 50. Nutrient cycling in forests. New Phytol. 124:561-582.

Bates, J. D., T. S. Svejcar, and R. F. Miller. 2007. Litter decomposition in cut and uncut western juniper woodlands. Journal of Arid Environments. 70:222-236.

Berg, B., and G. Ekbohm. 1991. Litter mass-loss rates and decomposition patterns in some needle and leaf litter types. Long-term decomposition in a Scots pine forest VII. Can. J. Bot. 
69:1449-1456.

Berg, B., and E. Matzner. 1997. Effect of N deposition on decomposition of plant litter and soil organic matter in forest systems. Environ. Rev. 5:1-25.

Berg, B. 1986. Nutrient release from litter and humus in coniferous forest soils-a mini review. Scandinavian J. For. Res. 1:359-369.

Blair, J. M., R. W. Parmelee, and M. H. Beare. 1990. Decay rates, nitrogen fluxesand decomposer communities of single- and mixed species foliar litter. Ecology, 71:5: 1976-1985.

Briones, M. J. I. and Ineson, P. 1996. Decomposition of eucalyptus leaves in litter mixtures. Soil Biol. Biochem.28:1381-1388.

Carreiro, M. M., R. L. Sinsabaugh, D. A. Repert, and D. F. Parkhurst. 2000. Microbial enzyme shifts explain litter decay responses to simulated N deposition. Ecology 81:2359-2365.

Chapman, K., J. B. Whittaker, and O. W. Heal. 1988. Metabolic and faunal activity in litter of tree mixtures compared with pure stands. Agric. Ecosyst. Environ. 24:33-40. 
Dix, N.J. and J. Webster. 1995. Fungal Ecology. 48-52. Chapman and Hall. Boca Raton. FL.

Finzi, A. C. and C. D. Canham. 1998. Non-additive effects of litter mixtures on net N mineralization in a southern New England forest. Forest Ecol. Manage. 105:129-136.

Fog, K. 1988. The effect of added $\mathrm{N}$ on the rate of decomposition of organic matter. Biological Review 63:433-462.

Fyles, J. W. and I. H. Fyles. 1993. Interaction of Douglas-fir with red alder and salal foliage litter during decomposition. Can. J. For. Res. 23:358-361.

Gartner, T. B. and Z. G. Cardon. 2004. Decomposition dynamics in mixed-species leaf litter. Oikos.104:230-246.

Gilliam, F. S., B. M. Yurish, and M. B. Adams. 2001. Temporal and spatial variation of nitrogen transformations in nitrogen-saturated soils of a central Appalachian hardwood forest. Can. J. For. Res. 31: $1768-1785$

Keyser, P., T. K. Kirk, and I. G. Zeikus. 1978. Lignolytic enzyme system of Phanerochaete chrysosporium: synthesized in the absence of lignin in response to nitrogen starvation. $\mathrm{J}$ Bacteriol 135:790-7. 
Knorr, M., S. D. Frey, and P. S. Curtis. 2005. Nitrogen additions and litter decomposition: A meta analysis. Ecology. 86 (12):3252-3257.

Hector, A., A. J. Beale, and A. Minns. 2000. Consequences of the reduction of plant diversity for litter decomposition: effects through litter quality and microenvironment. Oikos 90:357-371.

Knorr, M., S. D. Frey, and P. S. Curtis. 2005. Nitrogen additions and litter decomposition: A meta analysis. Ecology 86:3252-3257.

Magill, A. H., and J. D. Aber. 1998. Long-term effects of experimental N additions on foliar litter decay and humus formation in forest ecosystems. Plant Soil 203:301-311.

May, J. D., S. B. Burdette, F. S. Gilliam, and M. B. Adams. 2005. Interspecific divergence in foliar nutrient dynamics and stem growth in a temperate forest in response to chronic nitrogen inputs. Can. J. For. Res. 35: 1023-1030.

McTiernan, K. B., P. Ineson and P. A. Coward. 1997. Respiration and nutrient release from tree leaf litter mixtures. Oikos 78:527-538.

McArthur, J. V., J. M. Aho, R. B. Rader. 1994. Interspecific leaf interactions during decomposition in aquatic and floodplain ecosystems. J. N. Am. Benthol. Soc. 13:57-61. 
Melillo, J. M., J. D. Aber, and F. F. Muratore. 1982. Nitrogen and lignin control of hardwood leaf litter decomposition dynamics. Ecology 63:621-626.

Munasinghe, P. S., K. Piatek, W. Peterjohn, and M. B., Adams. 2008. Effects of Nitrogen deposition on foliar litter decomposition and C, N, Ca, and P dynamics in a central hardwood forest. Jonathan R. Cumming (unpublished)

Piatek, K. B. and H. L. Allen. 2001. Are forest floors in mid-rotation stands of loblolly pine (Pinus taeda) a sink for nitrogen and phosphorus? Can. J. For. Res. 31:1164-1174.

Prescott, C. E., L. M. Zabek, C. L. Staley, and R. Kabzems. 1990. Decomposition of broad leaf and needle litter in forests of British Columbia: influences of litter type, forest type, and litter mixtures. Can. J. For. Res. 30: 1742-1750.

Rustad, L. E. 1994. Element dynamics along a decay continuum in a red spruce ecosystem in Maine, USA. Ecology 75:867-879.

Rustad, L. E. and C. S. Cronan. 1988. Element loss and retention during litter decay in a red spruce stand in Maine. Ca. J. For. Res. 18:947-953. 
Seastedt, T. R. 1984. The role of microarthropods in decomposition and mineralization processes. Annu. Rev. Entomol. 29:25-46.

Salamanca, E. F., Kaneko, N. and S. Katagiri. 1998. Effects leaf litter mixtures on the decomposition of Quercus serrata and Pinus densiflora using field and laboratory microcosm methods. Ecol. Engineering 19:53-73.

Sinsabaugh, R. L., M. M. Carreiro, and D. A. Repert. 2002. Allocation of extracellular activity in relation to litter decomposition, $\mathrm{N}$ deposition, and mass loss. Biogeochemistry 60:1-24.

Staff, H. 1980. Influence of chemical composition, addition of raspberry leaves, and nitrogen supply on decomposition rate and dynamics of nitrogen and phosphorus in beach leaf litter. Oikos 35:55-62.

Taylor, B. R., W. F. J. Parsons and D. Parkinson. 1989. Decomposition of Populus tremuloides leaf litter accelerated by addition of Alnus crispa litter. Can. J. Forest Res. 19:674-679.

Wardle, D. A., K. I. Bonner, and K. S. Nicholson. 1997. Biodiversity and plant litter: experimental evidence which does not support the view that enhanced species richness improves ecosystem function. Oikos 79:247-258. 


\subsection{Bibliography}

Aber, J., K. J. Nadelhoffer, P. Steudler, and J. M. Melillo.1989. Nitrogen saturation in northern forest ecosystems. BioScience 39:378-386.

Aber, J., W. McDowell, K. Nadelhoffer, A. Magill, G. Berntson, M. Kamakea, S. McNulty, W.

Currie, L. Rustad and I. Fernandez.1998. Nitrogen saturation in temperate forest ecosystems. BioScience 48:921-934.

Adams, M. B. and T. R. Angradi. 1996. Decomposition and nutrient dynamics of hardwood leaf litter in the Fernow Whole-Watershed Acidification Experiment. For. Ecol. Manage. 83:61-69.

Adams, M. B., T. R. Angradi, and J. N Kochenderfer. 1997. Stream water and soil responses to five years of nitrogen and sulfur additions at the Fernow Experimental Forest, West Virginia. For. Ecol. Manage. 95:79-91. 
Adams, M. B., J. A. Burger, A. B. Jenkins, and L. Zelazny. 2000. Impact of harvesting and atmospheric pollution on nutrient depletion of eastern US hardwood forests. For. Ecol. Manage. 138:301-319.

Adams, M. B., J. Burger, L. Zelazny and J. Baumgras. 2004. Description of the Fork Mountain Long-term soil productivity study: site characterization. USDA For. Serv. Northeastern Research Station Gen. Tech. Rep. NE-323. 19.

Adams, M. B., J. N. Kochenderfer, and P. J. Edwards. 2007. The Fernow Watershed Acidification Study: Ecosystem Acidification, Nitrogen Saturation and Base Cation Leaching. Water Air Soil Pollut. 7:267-273.

Attiwill, P. M. 1980. Nutrient cycling in a Eucalyptus oblique (L' Herit.) forest. IV Nutrient uptake and nutrient return. Aust. J. Bot. 28:199-222.

Attiwill, P. M. and M. B. Adams. 1993. "Tansley Review” No. 50. Nutrient cycling in forests. New Phytol. 124:561-582.

Aber, J. D. 1992. Nitrogen cycling and nitrogen saturation in temperate forest ecosystems. Trends in Ecology and Evolution 7:220-223. 
Aber, J. D., A. Magill, S.G. McNulty, R. Boone, K. J. Nadelhoffer, M. Downs, and R. Hallet.1995. Forest biogeochemistry and primary production altered by $\mathrm{N}$ saturation. Water.Air.Soil.Pollut. 85:1665-1670.

Aber, J. D, C. L. Goodale, S. V. Ollinger, M. L. Smith, A. H. Magill, M. E. Martin, R. A. Hallett and J. L. Stoddard.2003. Is Nitrogen deposition altering the nitrogen status of northeastern forests? Bio Science 53:375-389.

Aerts, R. 1997. Climate, leaf litter chemistry and leaf litter decomposition in terrestrial ecosystems: A triangular relationship.Oikos 79:439-449.

Aerts, R. and H. De Caluwe. 1997. Nutritional and plant mediated controls on leaf litter decomposition of Carex species. Ecology 78:244-260.

Baath E, A. Frostegtd, T. Pennanen and H. Fritze. (1995). Microbial community structure and $\mathrm{pH}$ response in relation to soil organic matter quality in wood-ash fertilized, clear-cut or burned coniferous forest soils. Soil Biol. Biochem. 27: 229-240.

Bates, J. D., T. S. Svejcar, and R. F. Miller. 2007. Litter decomposition in cut and uncut western juniper woodlands. Journal of Arid Environments. 70:222-236. 
Baule, H. and C. Fricker. (1970). The Fertilizer Treatment of Forest Trees. Translated by C.L. Whittles. BLV Verlagsgesellschaft, Munchen.

Berg, B. 1984. Decomposition of moss litter in a mature Scots pine forest. Pedobiologia 26:301308.

Berg, B. 1986. Nutrient release from litter and humus in coniferous forest soils-a mini review. Scandinavian J. For. Res. 1:359-369.

B. Berg and H. Staff. 1980. Decomposition rate and chemical changes in decomposing needle litter of Scots pine. II. Influence of chemical composition. In: Persson, T. (ed.), Structure and function of northern coniferous forest. Ecol. Bull.32:373-390.

Berg, B. and E. Matzner. 1997. Effect of nitrogen deposition on decomposition of plant litter and soil organic matter in forst systems. Environ. Rev.5:1-25. 
Berg, B., H. Staff, and B. Wessen. 1987. Decomposition and nutrient release in needle litter from nitrogen fertilized Scots pine (Pinus silvestris) stands. Scand. J. For. Res. 2:399-415.

Berg, B. 2000. Litter decomposition and oranic matter turnover in northern forest soils. Forest Ecology and Mangement 133:13-22.

Birk, E. and P. Vitousek. 1984. Patterns of N retranslocation in loblolly pine stands response to $\mathrm{N}$ availability. Bulletin of the Ecological Society of America 65:100.

Brach, A. R. and D. J. Raynal. 1992. Effects of Liming on Oxalis acetosella and Lycopodium lucidulum in a Northern Hardwood Forest. The Journal of Applied Ecology 29:2: 492-500.

Bollen, W. B. 1953. Mulches and soil conditioners. Carbon and nitrogen in farm and forest products. Agricultural and Food Chemistry 7:379-381.

Berg, B. 1986. Nutrient release from litter and humus in coniferous forest soils-a mini review. Scandinavian J. For. Res. 1:359-369.

Blair, J. M., R. W. Parmelee, and M. H. Beare. 1990. Decay rates, nitrogen fluxesand decomposer communities of single- and mixed species foliar litter. Ecology, 71:5: 1976-1985. 
Briones, M. J. I. and Ineson, P. 1996. Decomposition of eucalyptus leaves in litter mixtures. Soil Biol. Biochem.28:1381-1388.

Baath, E., A. Frostegtd, T. Pennanen, and H. Fritze. (1995). Microbial community structure and $\mathrm{pH}$ response in relation to soil organic matter quality in wood-ash fertilized, clear-cut or burned coniferous forest soils. Soil Biol. Biochem. 27:229-240

Baker, T. G., and P. M. Attiwill. 1985. Loss of organic matter and elements from decomposing litter of Eucalyptus oblique L' Herit. and Pinus radiata D. Don. Australian For. Res. 15:309-319.

Bates, J. D., T. S. Svejcar, and R. F. Miller. 2007. Litter decomposition in cut and uncut western juniper woodlands. J. Arid Environ. 70:222-236.

Berg, B., and E. Matzner. 1997. Effect of N deposition on decomposition of plant litter and soil organic matter in forest systems. Environ. Rev. 5:1-25.

Berg, B., and G. Ekbohm. 1991. Litter mass-loss rates and decomposition patterns in some needle and leaf litter types. Long-term decomposition in a Scots pine forest. VII. Can. J. Bot. 69:1449-1456. 
Bryant, D. M., E. A. Holland, T. R. Seastedt, and M. D. Walker. 1998. Analysis of litter decomposition in an alpine tundra. Can. J. Bot. 76:1295-1304.

Carreiro, M. M., R. L. Sinsabaugh, D. A. Repert, and D. F. Parkhurst. 2000. Microbial enzyme shifts explain litter decay responses to simulated $\mathrm{N}$ deposition. Ecology 81:2359-2365.

Chapman, K., J. B. Whittaker, and O. W. Heal. 1988. Metabolic and faunal activity in litter of tree mixtures compared with pure stands. Agric. Ecosyst. Environ. 24:33-40.

Coulson, J. C. and J. Butterfield. 1978. An investigation of the biotic factors determining the rates of plant decomposition on blanket bog. J. Ecol. 66:631-650.

Cronan, C.S., W. A. Reiners, R. L. Reynolds, and G. E. Lang. 1978. Forest floor leaching: Contributions from mineral, organic, and carbonic acids in New Hampshire sub-alpine forests. Science 200:309-311.

Cronan, C.S. and D. F. Grigal. 1995. Use of Calcium/Aluminum ratios as indicators of stress in forest ecosystems. J. Environ. Qual. 24:209-226. 
Carreiro, M. M., R. L. Sinsabaugh, D. A. Repert, and D. F. Parkhurst. 2000. Microbial enzyme shifts explain litter decay responses to simulated N deposition. Ecology 81:2359-2365.

Chapman, K., J. B. Whittaker, and O. W. Heal. 1988. Metabolic and faunal activity in litter of tree mixtures compared with pure stands. Agric. Ecosyst. Environ. 24:33-40.

Dancer W. S., L. A. Peterson, and G. Chesters.1973. Ammonification and nitrification of N as influenced by soil $\mathrm{pH}$ and previous $\mathrm{N}$ treatments. Soil Sci. Soci. of America Proceedings 37: 6769.

Davidson, E. A., C. Stephen, H. Firestone, and M. K. Firestone. 1992. Internal cycling of nitrate in soils of a mature coniferous forest. Ecology 73:1148-1156.

De Forest, J. L., D. R. Zak, K. S. Pregitzer and A. J. Burton. 2004. Atmospheric nitrate deposition and the microbial degradation of cellulose and vanillin in a northern hardwood forest. Soil Biol. Biochem. 36:965-971.

DeHayes, D. H., P. G. Schaberg, G. J. Hawley and G. R. Strimbeck. 1999. Acid rain impacts on calcium and nutrition and forest health. Bio Science 10:789-800. 
Driscoll, C. T., C. P. Fahey, T. J. Blette, V. L. Bums, D. J. Gubala, C. P. Newton, R. M. Raynal, D. J. Schofield, C. F. Yavitt, and D. B. Porcella. 1996. The experimental watershed liming study (EWLS): Comparison of lakelwatershed base neutralization strategies. Biogeochemistry 32: 143174.

Dix, N.J. and J. Webster. 1995. Fungal Ecology. 48-52. Chapman and Hall. Boca Raton. FL.

Ebermayer, E. 1876. Die gesammte Lehre der Waldstreu, mit Rucksicht auf die chemische Statik des Waldbaues. Berlin: J. Springer.

Eriksen, J., R. D. B. Lefroy, and G. J. Blair. 1995a. Physical protection of soil organic S studied using acetylacetone extraction at various intensities of ultrasonic dispersion. Soil Biol. Biochem.27: 1005-1010.

Eriksen, J., R. D. B. Lefroy, and G. J. Blair.1995b. Physical protection of soil organic S studied by extraction and fractionation of soil organic matter. Soil Biol. Biochem. 27: 101 1-1016.

Finzi, A. C. and C. D. Canham. 1998. Non-additive effects of litter mixtures on net N mineralization in a southern New England forest. Forest Ecol. Manage. 105:129-136. 
Federer, C. A., J. W. Hornbeck, L. M. Tritton, C. W. Martin, R. S. Pierce, and C. T. Smith. 1989. Long-term depletion of calcium and other nutrients in eastern US forests. Environ. Manage. 13:593-601.

Fenn, M. E., M. A. Poth, J. D. Aber, J. S. Baron, B. T. Bormann, D. W. Johnson, A. D. Lemly, S. G. McNulty, D. F. Ryan, and R. Stottlemeyer. 1998. Nitrogen excess in North American ecosystems: Predisposing factors, ecosystem responses, and management strategies. Ecol. Appl. 8:706-733.

Fisher, R. F. and D. Binkley. 2000. Ecology and Management of forest soils. John Wiley and Sons Inc. New York.

Francis A. J. 1982. Effects of acidic precipitation and acidity on soil microbial processes. Water, Air \& Soil Pollution 18:375-394.

Freney J. R. and F. J. Stevenson.1967. Organic sulfur transformations in soils. Soil Sci. 101: 307-316.

Fog, K. 1988. The effect of added $\mathrm{N}$ on the rate of decomposition of organic matter. Biological Review 63:433-462. 
Fog, K. 1988. The effect of added N on the rate of decomposition of organic matter. Biological Review 63:433-462.

Fyles, J. W. and I. H. Fyles. 1993. Interaction of Douglas-fir with red alder and salal foliage litter during decomposition. Can. J. For. Res. 23:358-361.

Gilliam, F. S., M. B. Adams, and B. M. Yurish. 1996. Ecosystem nutrient responses to chronic nitrogen inputs at Fernow Experimental Forest, West Virginia. Can. J. For. Res. 16:196-205.

Gosz, J. R., G. E. Liken, and F. H. Borman. 1973. Nutrient release from decomposing leaf and branch litter in the Hubbard Brook Forest, New Hampshire. Ecological Monographs 43:173191.

Galloway, J. N., S. A. Norton, and M. R. Church. 1983. Freshwater acidification from atmospheric deposition of sulfuric acid: A conceptual model. Environ. Sci. Technol.17:541-545.

Galloway, J. N., G. E. Likens, and M. E. Hawley. 1984. Acid precipitation: Natural versus anthropogenic components. Science.226:829-831. 
Gaston, L. A., R. S. Mansell and R. D. Rhue. 1986. Sulfate mobility in acid soils and implications with respect to cation leaching: a review. Soil Crop Sci. Soc. Fla. Proc. 45:67-72.

Gregan, P.D., J. R. Hirth and M. K. Conyers. 1989. Amelioration of soil acidity by liming and other amendments.Soil Acidity and Plant Growth (ed.) A.D. Robson. 205-264. Academic Press, New York.

Gress, S. E., T. D. Nichols, C. C. Northcraft, and W. T. Peterjohn. 2007. Nutrient limitation in soils exhibiting differing nitrogen availabilities: What lies beyond nitrogen saturation? Ecology. 88: 119-130.

Gartner, T. B. and Z. G. Cardon. 2004. Decomposition dynamics in mixed-species leaf litter. Oikos.104:230-246.

Gilliam, F. S., B. M. Yurish, and M. B. Adams. 2001. Temporal and spatial variation of nitrogen transformations in nitrogen-saturated soils of a central Appalachian hardwood forest. Can. J. For. Res. 31: 1768-1785

Haynes R. J. and R. S. Swift.1988. Effects of lime and phosphate additions on changes in enzyme activities, microbial biomass and levels of extractable nitrogen, sulfur and phosphorus in an acid soil. Biol. Fertil. Soils 6:153-158. 
Hector, A., A. J. Beale, and A. Minns. 2000. Consequences of the reduction of plant diversity for litter decomposition: effects through litter quality and microenvironment. Oikos 90:357-371.

Halm, B. J., J. W. B. Stewart, and R. L. Halstead. 1972. The phosphorus cycle in a native grassland ecosystem. In: Isotopes and radiation in soil-plant relationships, including forestry. Vienna: International Atomic Energy Agency 571-586.

Helvey, J. D. and S. H. Kunkle. 1986. Input-out budgets of selected nutrients on an experimental watershed near Parsons, West Virginia. Res. Pap. NE-584. Broomall, PA: USDA For. Serv. Northeastern Forest Experiment Station. 7p.

Hobbie, S. E. 2000. Interactions between litter lignin and soil nitrogen availability during leaf litter decomposition in a Hawaiian Montane Forest. Ecosystems 3:484-494.

Hobbie, S. E., and P. M. Vitousek. 2000. Nutrient limitation of decomposition in Hawaiian forests. Ecology 81:1867-1877.

Hunt, H. W., E. R. Ingham, D. C. Coleman, E. T. Elliot, and C. P. P. Reid. 1988. N limitation of production and decomposition in prairie, mountain meadow, and pine forest. Ecology 69:10091016. 
Heilman, P. 1974. Effect of urea fertilization on nitrification in forest soils of the Pacific Northwest. Soil Science Society of America Proceedings 38: 664-667.

Huntington, T. G., R. P. Hooper, and B. T. Aulenbach. 1994. Hydrologic processes controlling sulfur mobility: A small watershed approach. Water Resour. Res.30:283-295.

Huntington, T. G., R. P. Hooper, C. E. Johnson, B. T. Aulenbach, R. Cappellato and A. E. Blum. 2000. Calcium depletion in a southeastern United States forest ecosystem. Soil Sci.Soc. Am. J. 64:1845-1858.

Hyman, M. E., C. E. Johnson, S. W. Bailey, R. H. April and J. W. Hornbeck. 1998. Chemical weathering and cation loss in a base-poor watershed. GSA Bulletin 110:85-95.

Ito, M., M. J. Mitchell, and C. T. Driscoll. 2002. Spatial patterns of precipitation quantity and chemistry and air temperature in the Adirondack region of New York. Atmos. Environ. 36:10511062. 
Jansson, S. L.1958. Tracer studies on nitrogen transformations in soil with special reference to mineralization-immobilization relationships. Kungl. Lantbruksshogskolans Annaler 24:101-361.

Johnson, D. W., and D. W. Cole. 1977. Sulfate mobility in an outwash soil in western Washington. Water Air Soil Pollut.7:489-495.

Johnson, D. W., H. V. Miegroet, D. W. Cole, and D. D. Richter. 1983. Contributions of acid deposition and natural processes to cation leacing from forest soils: a review. J. Air Pollut. Control Assoc. 33:1036-1041.

Johnson, D. W. and R. VanHook .1989. Analysis of biogeochemical cycling processes in Walker Branch Watershed. Springer-Verlag, New York.

Johnson, A. H., T. N. Schwartzman, J. J. Battles, R. Miller, A. J. Friedland and D. R. Vann.1994. Acid rain and soils of the Adirondacks. II. Evaluation of calcium and aluminum as causes of red spruce decline at Whiteface Mountain, New York. Can. J. For. Res. 24:654-662.

Johnson, D. W., G. S. Henderson, and D. E. Todd. 1988. Changes in nutrient distribution in forests and soils of Walker Branch Watershed, Tennessee over an eleven year period. Biogeochemistry 5:275-293. 
Keyser, P., T. K. Kirk, and I. G. Zeikus. 1978. Lignolytic enzyme system of Phanerochaete chrysosporium: synthesized in the absence of lignin in response to nitrogen starvation. J Bacteriol 135:790-797.

Kirchner, J. W. and E. Lydersen. 1995. Base cation depletion and potential long-term acidification of Norwegian catchments. Environmental Science and Technology 29:1953-1960.

Knorr, M., S. D. Frey, and P. S. Curtis. 2005. Nitrogen additions and litter decomposition: A meta analysis. Ecology 86:3252-3257.

Korentajer, L., B. H. Brynes, and D. T. Hellums.1983. The effect of liming and leaching on the sulfur-supplying capacity of soils. Soil Sci. Soc. Am. J. 47: 525-530.

Kutbay, H. G. and T. Ok. 2003. Foliar N and P resorption and nutrient levels along an elevational gradient in Juniperus oxycedrus L. subsp. macrocarpa (Sibth. \& Sm.) Ball. Ann. For. Sci. 60:449-454.

Lavelle, P., E. Blanchart, A. Martin, A. Spain, F. Toutain, I. Barois, and R. Schaefer. 1993. A hierarchical model for decomposition in terrestrial ecosystems: application to soils of the humid tropics. Biotropica 25:130-150. 
Likens, G. E., C. T. Driscoll, and D. C. Buso. 1996. Long-term effects of acid rain: response and recovery of a forest ecosystem. Science 272:244-246.

Likens, G. E., C. T. Driscoll, D. C. Buso, T. G. Siccama, C. E. Johnson, G. M. Lovett, T. J. Fahey, W. A. Reiners, D. F. Ryan, C. W. Martin and S. W. Bailey. 1998. The biogeochemistry of calcium at Hubbard Brook. Biogeochemistry 41:89-173.

Lyngstad, I. 1992. Effect of liming on mineralization of soil nitrogen as measured by plant uptake and nitrogen released during incubation. Plant and Soil 144: 247-253

Mahony, N., E. Nol, and T. Hutchinson. 1997. Food chain chemistry, reproductive success, and foraging behaviour of songbirds in acidified maple forests of central Ontario. Canadian journal of Zoology 75:509-517.

Mann, L. K., D. W. Johnson, D. C. West, D. W. Cole, J. W. Hornbeck, C. W. Martin, H. Riekerk, C. T. Smith, W. T. Swank, L. M. Tritton, and D. H. van Lear. 1988. Effects of wholetree and stem-only clearcutting on postharvest hydrologic losses, nutrient capital and regrowth. For. Sci. 34:412-428. 
Marschner, H. 1986. Mineral nutrition of higher plants. London Academic Press Harcourt Brace Jovanovich.

Marschner, B. and A. W. Wilczynski.1991. The effect of liming on quantity and chemical composition of soil organic matter in a pine forest in Berlin, Germany. Plant and Soil 137:229236.

Marschner, B. 1993. Microbial contribution to sulphate mobilization after liming an acid forest soil. J. Soil Sci. 44: 459-466.

Mayor, X. and F. Roda. 1992. Is primary production in holm oak forests nutrient limited? Plant Ecology 99:209-217.

McArthur, J. V., J. M. Aho, R. B. Rader. 1994. Interspecific leaf interactions during decomposition in aquatic and floodplain ecosystems. J. N. Am. Benthol. Soc. 13:57-61.

McClaugherty, C., and B. Berg. 1987. Cellulose, lignin, and N concentrations as rate regulating factors in late stages of forest litter decomposition. Pedobiologia 30:101-112.

McLaughlin, S. B. and R. Wimmer. 1999. Tansley Review:104: Calcium physiology and terrestrial ecosystem processes. New Phytologist 142:373-417. 
McTiernan, K. B., P. Ineson and P. A. Coward. 1997. Respiration and nutrient release from tree leaf litter mixtures. Oikos 78:527-538.

Melillo, J. M., J. D. Aber, and J. F. Muratore. 1982. Nitrogen and lignin control of hardwood leaf litter decomposition dynamics. Ecology 63:621-626.

Miegroet, H. V., D. W. Cole, and N. W. Foster. 1992. Nitrogen distribution and cycling. In Johnson, D.C., and S.E. Lindberg (eds.). Atmospheric Deposition and Forest Nutrient Cycling: A synthesis of the Integrated Forest Study. Ecological Ser.91. Springer-Verlag, New York.

Mitchell, H. L., and R. F. Chandler, JR. 1939. The nitrogen nutrition and growth of certain deciduous trees of northeastern United States: with a discussion of the principles and practice of leaf analysis as applied to forest trees. The Black Rock Forest 11:1-94.

Munasinghe, P. S., K. Piatek, W. Peterjohn, and M. B., Adams. 2008. Effects of Nitrogen deposition on foliar litter decomposition and $\mathrm{C}, \mathrm{N}, \mathrm{Ca}$, and $\mathrm{P}$ dynamics in a central hardwood forest. Jonathan R. Cumming (unpublished)

Nambiar, E. K. S. and D. N. Fife. 1991. Nutrient retranslocation in temperate conifers. Tree Physiology. 9:185-207. 
Nasholm, T. 1994. Removal of nitrogen during needles senescence in Scots pine (Pinus sylvestris L.). Oecologia. 99:290-296.

Nihlgard, B.1985. The ammonium hypothesis, an additional explanation to the forest dieback in Europe. Ambio 14:2-8.

Nyborg, M. and P. B. Hoyt. 1978. Effects of acidity and liming on mineralization of soil nitrogen. Can. J. of Soil Sci. 58: 33 1-338.

O'Connell, A. M. 1988. Nutrient Dynamics in decomposing litter in karri (Eucalyptus diversicolor F. Muell) forests of south western Australia. J. Ecol. 76:1186-1203.

Olson, J. S. 1963. Energy storage and the balance of producers and decomposers in ecological systems. Ecology 44:322-331.

Ollinger, S. V., J. D. Aber, G. M. Lovett, S. E. Millham, R.G. Lathrop, and J. M. Ellis. 1993. A spatial model of atmospheric deposition for the northeastern Unites States. Ecological Applications 3:459-472.

Pastor, J., M. A.Stillwell, and D. Tilman. 1987. Little blue stem litter dynamics in Minnesota old fields. Oecologia 72:327-330. 
Paul, E. A. and F. E. Clark. 1989. Soil microbiology and biochemistry. San Diego, Academic Press.

Persson T., J. Lundkvist, A. Wirh, R. Hyvonen, and, B. 'NessLn.1989. Effects of acidification and liming on carbon and nitrogen mineralization and soil organisms in mor humus. Water, Air and Soil Pollution 45:77-96.

Peterjohn, W. M., M. B. Adams, and F. S. Gilliam. 1996. Symptoms of nitrogen saturation in two central Appalachian hardwood forest ecosystems. Biogeochemistry 35:507-522.

Piatek, K. B. and H. L. Allen. 2001. Are forest floors in mid-rotation stands of loblolly pine (Pinus taeda) a sink for nitrogen and phosphorus? Can. J. For. Res. 31:1164-1174.

Prescott, C. E., L. M. Zabek, C. L. Staley, and R. Kabzems. 1990. Decomposition of broad leaf and needle litter in forests of British Columbia: influences of litter type, forest type, and litter mixtures. Can. J. For. Res. 30: 1742-1750.

Prescott, C. E. 1995. Does N availability control rates of litter decomposition in forests? Plant Soil 168-169:83-88. 
Raynal, D. J., N. W. Foster, M. J. Mitchell, and D. W. Johnson. 1992. Eastern hardwoods. In: D. W. Johnson, S. E. Lindberg (Eds.), Acidic deposition and forest nutrient cycling. Springer, New York, pp. 526-534.

Reuss, J. O., and D. W. Johnson. 1986. Acid deposition and acidification of soils and waters.Springer-Verlag, New York.

Rovira, A. D. 1969. Plant root exudates. Botanical Review 35:35-37.

Rustad, L. E. and C. S. Cronan. 1988. Element loss and retention during litter decay in a red spruce stand in Maine. Ca. J. For. Res. 18:947-953.

Rustad, L. E. 1994. Element dynamics along a decay continuum in a red spruce ecosystem in Maine, USA. Ecology 75:867-879.

Romkens, P. F., J. Bril, and W. Salomons. 1996. Interactions between $\mathrm{Ca}^{2+}$ and dissolved carbon: implications for metal mobilization. Appl. Geochem. 11:109-115.

Salamanca, E. F., Kaneko, N. and S. Katagiri. 1998. Effects leaf litter mixtures on the decomposition of Quercus serrata and Pinus densiflora using field and laboratory microcosm methods. Ecol. Engineering 19:53-73. 
Smith, C. T., M. L. J. McCormack, J. W. Hornbeck, and C. W. Martin. 1986. Nutrient and biomass removals from a red spruce-balsam fir whole-tree harvest. Can. J. For. Res. 16:381-388.

Stoddard, J. L. 1994. Long-term changes in watershed retention of nitrogen: Its causes and consequences. Pages 223-282 In Baker L. A. (Ed). Environmental Chemistry of Lakes and Reservoirs. Am. Chem. Soc. Washington DC.

Safford, L.O. 1974. Effect of fertilization on biomass and nutrient content of fine roots in a beech-birch-maple stand. Plant and Soil 40: 349-363.

Sahrawat, K. L., D. R. Keeney and S. S. Adams. 1985. Rate of aerobic nitrogen transformations in six acid climax forest soils and the effect of phosphorus and $\mathrm{CaC0}_{3}$. For.Sci. 31: 680-684.

Schaefer, D. A., P. Coklin, and K. Knoerr. 1992. Atmospheric deposition of acids. In Johnson, D.C., and S.E. Lindberg (eds.). Atmospheric Deposition and Forest Nutrient Cycling: A synthesis of the Integrated Forest Study. Ecological Ser.91. Springer-Verlag, New York.

Schaberg, P. G., T. D. Perkins, and S. G. McNulty. 1997. Effects of chronic low-level N additions on foliar elemental concentrations, morphology, and gas exchange of mature montane red spruce. Can. J. For. Res. 27:1622-1629. 
Schaberg, P. G., D. H. DeHayes, and G. Hawley. 2001. Anthropogenic Calcium depletion: A unique threat to forest ecosystem health Ecosystem Health. 7:214-228.

Schlesinger, W. H. and M. M. Hasey. 1981. Decomposition of chaparral shrub foliage: losses of organic and inorganic constituents from deciduous and evergreen leaves. Ecology 62:762-774.

Seastedt, T. R. 1984. The role of microarthropods in decomposition and mineralization processes. Annu. Rev. Entomol. 29:25-46.

Shah, Z., W. A. Adams and C. D. V. Haven. 1990. Composition and activity of the microbial population in an acidic upland soil and effects of liming. Soil Biol.and Biochemistry 22: 257-263

Singh, B. R., G. Abrahamsen and A. Stuanes.1980. Effects of simulated acid rain on sulfate movement in acid forest soils. Soil Sci. Soc. Am J. 44:75-80.

Sinsabaugh, R. L., M. M. Carreiro and D. A. Repert. 2002. Allocation of extracellular enzymatic activity in relation to litter decomposition, $\mathrm{N}$ deposition and mass loss. Biogeochemistry 60:1-24.

Simmons, J. A., J. B. Yavitt, and T. J. Fahey. 1996. Watershed Liming Effects on the Forest Floor N Cycle Biogeochemistry 32: 221-244. 
Smith, W. H. 1976. Character and significance of forest tree root exudates. Ecology 57:324-331.

Smith, C. T., M. L. J. McCormack, J. W. Hornbeck, and C. W. Martin. 1986. Nutrient and biomass removals from a red spruce-balsam fir whole-tree harvest. Can. J. For. Res. 16:381-388.

Staff, H. and B. Berg. 1982. Accumulation and release of plant nutrients in decomposing Scots pine needle litter. II. Long-tern decomposition in a Scots pine forest. Can. J. Bot. 60:1561-1568.

Stoddard, J. L. 1994. Long-term changes in watershed retention of nitrogen: Its causes and consequences. Pages 223-282 In Baker L. A. (Ed). Environmental Chemistry of Lakes and Reservoirs. American Chemical Society, Washington DC.

Swank, W. T., and D. A. J. Crossley. 1988. Forest hydrology and ecology at Coweeta. SpringerVerlag, New York.

Swift, M. J., O. W. Heal, and J. M. Anderson. 1979. Decomposition in Terrestrial Ecosystems. University of California Press Berkeley CA. 
Tamm, C. O. 1964. Determination of nutrient requirements of forests of forest stands, In: Romberger J. A., Mikola P. (Eds.), International Review of Forestry Research, Academic Press, New York, 1964, pp. 115-170.

Taylor, B. R., D. Parkinson and W. F. J. Parsons. 1989. Nitrogen and lignini contents as predictors of litter decay rates: a microcosm test. Ecology 70:97-104.

Tian, G., B. T. Kang and L. Brussaard. 1992a. Biological efforts of plant residues with contrasting chemical composition under humid tropical conditions-decomposition and nutrient release. Soil Biol. Biochem. 24:1051-1060.

Tian, G., B. T. Kang, and L. Brussaard. 1992b. Effects of chemical composition on N, Ca and $\mathrm{Mg}$ release during incubation of leaves from selected agroforestry and fallow plant species. Biogeochemistry 16:103-119.

Taylor, B. R., W. F. J. Parsons and D. Parkinson. 1989. Decomposition of Populus tremuloides leaf litter accelerated by addition of Alnus crispa litter. Can. J. Forest Res. 19:674-679. 
Taussky, H. H. and E. Shorr. 1953. A microcolorimetric method for the determination of inorganic phosphorus. J. Biol. Chem. 202:675-685.

Valeur, I., S. Andersson, I. Nilsson. 2000. Calcium Content of Liming Material and Its Effect on Sulphur Release in a Coniferous Forest Soil. Biogeochemistry 50:1:1-20

Van Vuuren, M. M. I., B. Van Wesemael and M. A. C. Veer. 1993. Soil organic matter accumulation, litter decomposition and humus forms under Mediterranean-type forets in southern Tuscany Italy. J. Soil Scie. 43:133-144.

Van Dijk, H. and J. G. M. Roelofs. 1988. Effects of excessive ammonium deposition on the nutritional status and condition of pine needles. Physiol. Plant. 73:494-501.

Vitousek, P. M., W. J. Parton, and R. L. Sanford. 1994. Litter decomposition on the Mauna Loa environmental matrix, Hawaii: patterns, mechanisms and models. Ecology 75:418-429.

Vitousek, P. M., J. D. Aber, R. W. Howarth, G. E. Likens, P. A. Matson, D. W. Schindler, W. H. Schlesinger and D. G. Tilman. 1997. Human alteration of the global nitrogen cycle: sources and consequences. Ecol. Appl. 7:737-750. 
Wardle, D. A., K. I. Bonner, and K. S. Nicholson. 1997. Biodiversity and plant litter: experimental evidence which does not support the view that enhanced species richness improves ecosystem function. Oikos 79:247-258.

Wallenda, T. and Kottke, I. 1998. Nitrogen deposition and Ectomycorrhiza. New Phytologist 139:169-187.

Williams, C. H. 1967. Some factors affecting the mineralization of organic sulfur in soils. Plant and Soil 26: 205-223.

Zoettl, H.W., and R.F. Huettl.1986. Nutrient supply and forest decline in southwest Germany. Water. Air. and Soil. Pollution 31:449-462.

Zogg, G., D. R. Zak, K. S. Pregitzer and A. J. Burton. 2000. Microbial immobilization and the retention of anthropogenic nitrate in a northern hardwood forest. Ecology 81:1858-1866. 